INTERNATIONAL MONETARY FUND
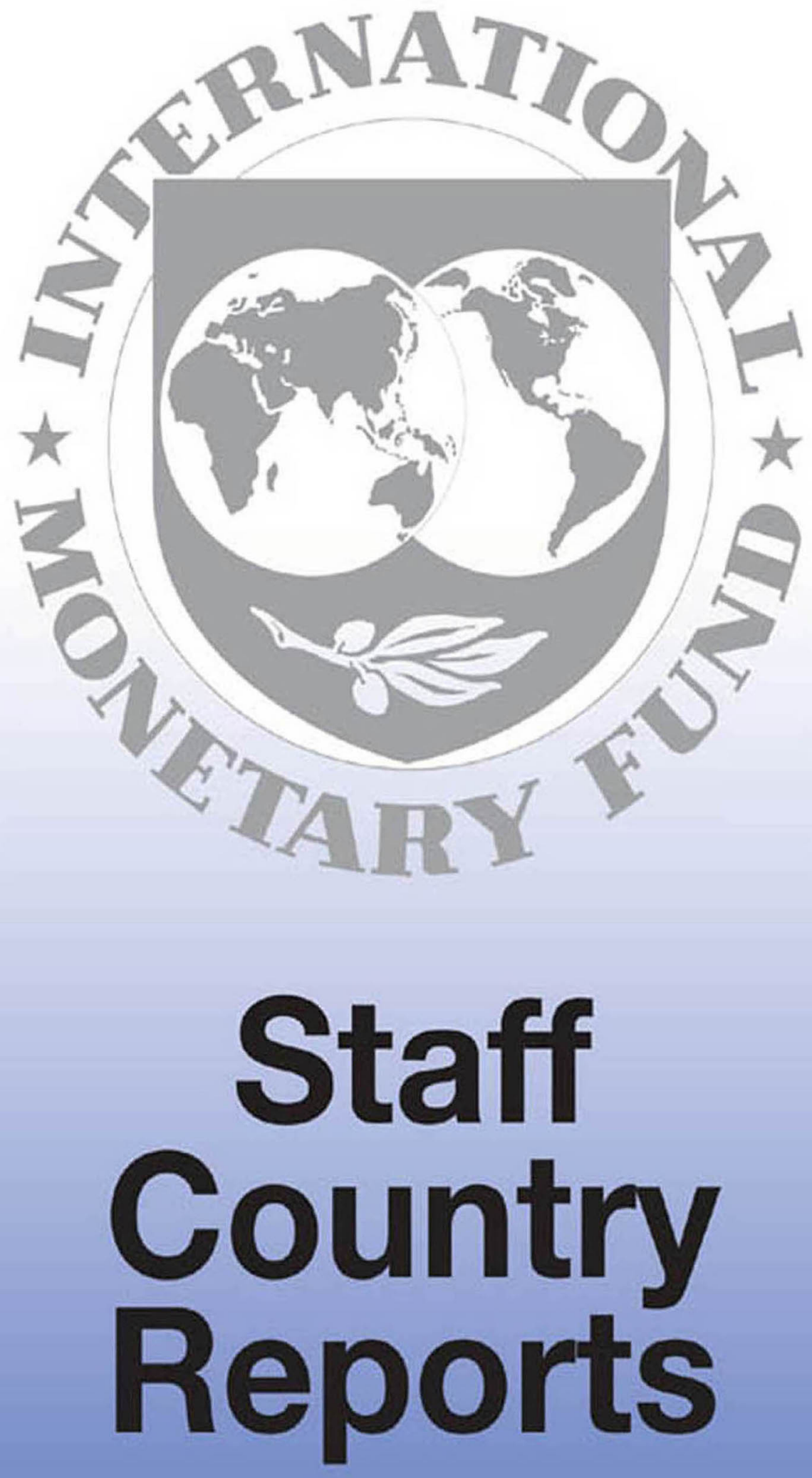


\title{
Guinea: Enhanced Initiative for Heavily Indebted Poor Countries-Completion Point Document and Multilateral Debt Relief Initiative
}

This paper was prepared by staffs of the International Monetary Fund and the World Bank in connection with the Executive Board's consideration of Guinea's Completion Point under the Enhanced Initiative for Heavily Indebted Poor Countries and debt relief under the Multilateral Debt Relief Initiative. It is based on the information available at the time it was completed on September 11, 2012. The views expressed in this document are those of the staff team and do not necessarily reflect the views of the government of Guinea or the Executive Board of the IMF.

The following documents have been released and are included in this package:

- A Press Release summarizing the views of the staffs of the International Monetary Fund and the World Bank.

- A Statement by the Executive Director for Guinea.

The documents listed below have been separately released:

- Joint Staff Advisory Note on the Extended Poverty Reduction Strategy Paper 2011-12 and the 2011 Progress Report

- Poverty Reduction Strategy Paper-Progress Report

The policy of publication of staff reports and other documents allows for the deletion of marketsensitive information.

Copies of this report are available to the public from

$$
\begin{aligned}
& \text { International Monetary Fund } \bullet \text { Publication Services } \\
& 70019^{\text {th }} \text { Street, N.W. • Washington, D.C. } 20431
\end{aligned}
$$

Telephone: (202) 623-7430 • Telefax: (202) 623-7201

E-mail: publications@imf.org • Internet: http://www.imf.org

\author{
International Monetary Fund \\ Washington, D.C.
}




\title{
INTERNATIONAL DEVELOPMENT ASSOCIATION AND \\ INTERNATIONAL MONETARY FUND
}

\author{
GUINEA
}

\section{Enhanced Initiative for Heavily Indebted Poor Countries Completion Point Document and Multilateral Debt Relief Initiative}
Prepared by the Staffs of the International Development Association and the International Monetary Fund

Approved by Makhtar Diop and Otaviano Canuto (IDA)

Doris Ross and Thomas Dorsey (IMF)

September 11, 2012

Contents

List of Acronyms $\underline{3}$

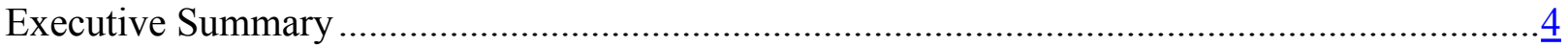

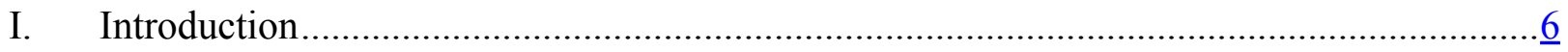

II. Assessment of Requirements for Reaching the Floating Completion Point.........................

A. Poverty Reduction.................................................................................................

B. Macroeconomic and Structural Reforms ........................................................11

C. Governance and Anti-Corruption Actions .......................................................

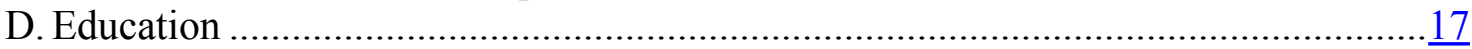

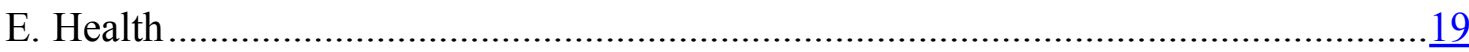

III. Updated Debt Relief and Sustainability Analysis.........................................................19

A. Revision of Data Reconciliation as of the Decision Point ......................................19

B. Revision of HIPC Assistance and Status of Creditor Participation ...........................

C. Considerations for Exceptional Topping-Up Assistance...........................................24

D. Creditor Participation in the Multilateral Debt Relief Initiative ...............................25

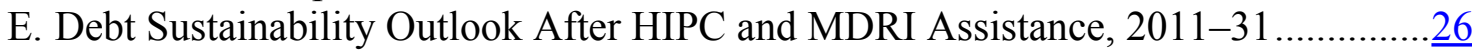

F. Sensitivity Analysis and Long-Term Debt Sustainability .......................................28

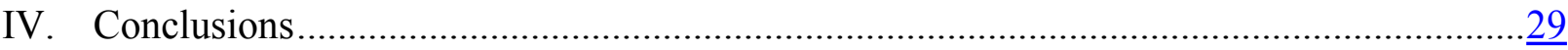

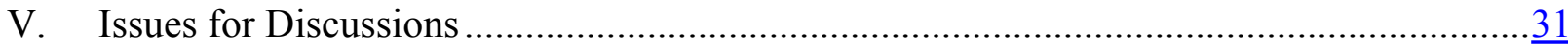


Boxes

1. Status of Floating Triggers (As of end-July 2012) ................................................... $\underline{8}$

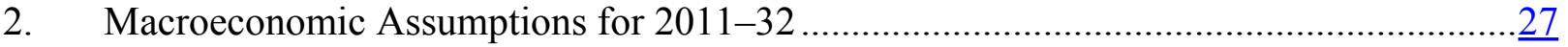

Figures

A1. Composition of External Debt by Creditor Groups, End-1999 and End-2011 _................32

A2. External Debt and Debt Service Indicators for Medium- and Long-Term

Public Sector Debt, 2011-31 ................................................................... 33

A3. Sensitivity of Long-Term Debt Sustainability after Shocks, 2011-31 ..........................34

Tables

1. Selected Economic and Financial Indicators, 2008-16 …..................................... 15

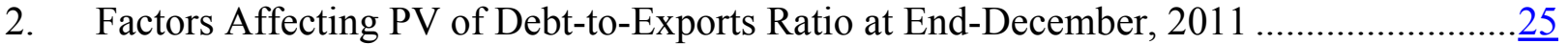

A1. Comparison of Discount Rate and Exchange Rate Assumptions ....................................

A2. Revised Nominal Stocks and Net Present Value of Debt at Decision Point by

Creditor Groups (As of end-1999) .$\underline{36}$

A3. Nominal and Present Value of External Debt outstanding at End-December $2011 \ldots \ldots \ldots . . .37$

A4. Revised Nominal and Present Value of Debt at Decision Point by Creditor Groups

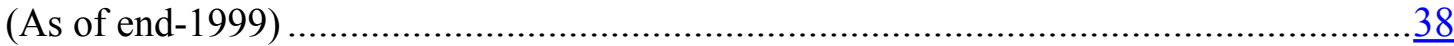

A5. External Debt Service ....................................................................................

A6. Present Value of External Debt............................................................................ $\frac{41}{43}$

A7. Key External Debt Indicators, 2011-31.............................................................. 43

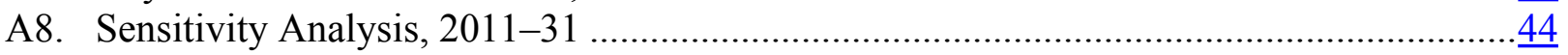

A9. Delivery of IDA Assistance Under the Enhanced HIPC Initiative and the

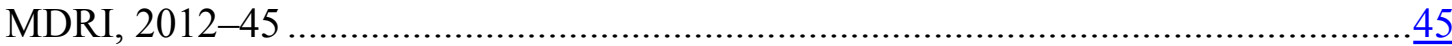

A10. Possible Delivery of IMF Assistance Under the Enhanced HIPC Initiative and the ............

MDRI, 2000-22 ........................................................................... $\frac{46}{47}$

A11. Status of Creditor Participation Under the Enhanced HIPC Initiative ............................ 47

A12. Paris Club Creditors' Delivery of Debt Relief Under Bilateral Initiatives beyond the

HIPC Initiative ..................................................................................

A13. HIPC Initiative-Status of Country Cases Considered

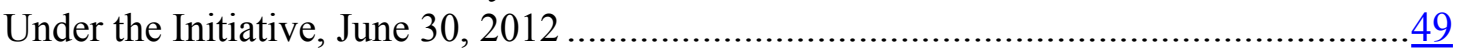

Appendices

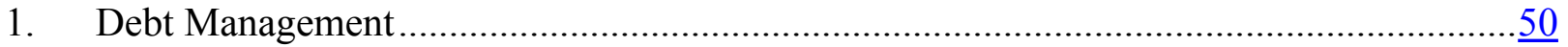

2. Joint Bank-Fund Debt Sustainability Analysis Under the Debt Sustainability ....................

Framework for Low-Income Countries ........................................................ $\underline{52}$ 


\section{LIST OF ACRONYMS}

\begin{tabular}{|l|l|}
\hline AfDB/AfDF & African Development Bank/African Development Fund \\
\hline AFRITAC & African Regional Technical Assistance Center \\
\hline ANLC & National Anti Corruption Agency \\
\hline BADEA & Arab Bank for Economic Development in Africa \\
\hline CNLS & Anti Corruption Committee \\
\hline CNT & National Transition Committee \\
\hline CWIQ & Core Welfare Indicators Questionnaire Survey \\
\hline DHS & Demographic and Health Survey \\
\hline DRA & Debt Relief Analysis \\
\hline DTP3 & Diphtheria, Tetanus and Pertussis \\
\hline ECOWAS & Economic Community of West African States \\
\hline EBID & ECOWAS Bank for Investment and Development \\
\hline ECF & Extended Credit Facility \\
\hline EFA-FTI & Education For All-Fast Track Initiative \\
\hline EIB & European Investment Bank \\
\hline EIBEP & $\begin{array}{l}\text { Enquête Intégrée de Base pour l'Evaluation de la Pauvreté (integrated } \\
\text { baseline household expenditure survey) }\end{array}$ \\
\hline EU & European Union \\
\hline GDP & Gross Domestic Product \\
\hline GNF & Guinean Franc \\
\hline HIPC & Heavily Indebted Poor Country \\
\hline IDA & International Development Association \\
\hline IFAD & International Fund for Agricultural Development \\
\hline IMF & International Monetary Fund \\
\hline IsDB & Islamic Development Bank \\
\hline JSAN & Joint Staff Advisory Note \\
\hline LIC-DSA & Low-Income Country Debt Sustainability Analysis \\
\hline MDG & Millennium Development Goal \\
\hline MDRI & Multilateral Debt Relief Initiative \\
\hline MFI & Micro-Finance Institution \\
\hline MICS & Multiple Indicators Cluster Survey \\
\hline NGO & Non Governmental Organization \\
\hline NSO & National Statistical Office \\
\hline ODA & Official Development assistance \\
\hline OFID & OPEC Fund for International Development \\
\hline OPEC & Organization of the Petroleum Exporting Countries \\
\hline PPA & Participatory Poverty Assessment \\
\hline PPG & Public and Publicly guaranteed \\
\hline PR & Progress Report \\
\hline PRGF & Poverty Reduction and Growth Facility \\
\hline PRSP & Poverty Reduction Strategy Paper \\
\hline PV & Present Value \\
\hline SIMFER & Simandou Fer (Simandou Iron Ore Project) \\
\hline SMP & Staff-Monitored Program \\
\hline UNDP & United Nations Development Program \\
\hline & \\
\hline
\end{tabular}




\section{EXECUTIVE SUMMARY}

1. In December 2000, the Boards of Executive Directors of IDA and the IMF agreed that the Republic of Guinea had met the requirements for reaching the Decision Point under the Enhanced Heavily Indebted Poor Countries (HIPC) Initiative. The amount of debt relief committed at the decision point was $\$ 545$ million in end-1999 present value (PV) terms, calculated to reduce the PV of eligible external debt to 150 percent of exports at end-1999. This relief implied a common reduction factor of 31.6 percent.

\section{In the view of the staffs of IDA and the IMF, Guinea has made satisfactory} progress in meeting the requirements for reaching the floating completion point. The key decisions, actions and measures required to fulfil all but one of the triggers have been taken, including the preparation of a full Poverty Reduction Strategy Paper (PRSP) and its satisfactory implementation for at least one year (Trigger \#1); improvement of the poverty database and monitoring capacity (Trigger \#2); continued maintenance of macroeconomic stability as evidenced by satisfactory implementation of the PRGF supported program (Trigger \#3); ${ }^{1}$ develop and take steps to provide an appropriate regulatory framework for microcredit institutions (Trigger \#4); publication of a progress report on the activities of the Anti-Corruption Committee (Trigger \#5); increase in gross enrolment rates for girls and boys in primary schools (Trigger \#7); annual increase in the number of primary school teachers (Trigger \#8); increase in DTP3 vaccination coverage (Trigger \#9); and increase in the percentage of pregnant women receiving prenatal consultations (Trigger \#10). With regard to the audit of all government procurement contracts over GNF 100 million (Trigger \#6); very good progress was made, although, given the limited capacity, starting from 2008 the authorities followed a less ambitious but more practical system of quarterly audits, covering a representative sample of large contracts. The authorities are requesting a waiver for not having audited all contracts; the staffs of the IDA and the IMF support this request since the broad objective of the trigger was achieved and implementation has improved.

3. The required HIPC assistance in end-1999 PV terms has been revised upward to $\$ 639$ million. As a result of the debt reconciliation exercise for the completion point, the PV of eligible external debt has increased, while the estimate of exports was decreased. Consequently, the required HIPC assistance to reduce the PV of debt to exports to 150 percent has increased by $\$ 93.7$ million, from $\$ 545.4$ million estimated at the decision point to $\$ 639$ million. Correspondingly, the common reduction factor has increased from 31.6 percent to 36.2 percent. $\$ 383$ million would be delivered by multilateral creditors and $\$ 256$ million by bilateral and commercial creditors.

\section{Guinea does not qualify for topping-up under the Enhanced HIPC Initiative based on end-2011 debt data.}

\footnotetext{
${ }^{1}$ The Poverty Reduction and Growth Facility (PRGF) has been succeeded by the Extended Credit Facility (ECF).
} 
5. Creditors accounting for 97.5 percent of total HIPC eligible debt have given satisfactory assurances of their participation in the enhanced HIPC Initiative. Nearly all multilateral creditors and Paris Club creditors have agreed to participate. The authorities are working toward obtaining participation of all the remaining creditors. ${ }^{2}$

6. Upon reaching the completion point under the Enhanced HIPC Initiative, Guinea will also qualify for additional debt relief under the Multilateral Debt Relief Initiative (MDRI). Debt relief under the MDRI would cover most remaining debt service obligations to IDA and the African Development Fund (AfDF). MDRI relief would save Guinea $\$ 964$ million in debt service over 40 years.

7. Full delivery of HIPC, additional bilateral assistance beyond HIPC, and MDRI debt relief at the completion point would reduce Guinea's external debt burden significantly. The PV of debt-to-exports ratio would fall from 186.0 percent at end-2011 to 48.9 percent at end-2012. Thereafter, it is projected to fall further to 17.7 percent at end-2031, mainly attributable to an increase in exports following the start of production of a mining project in 2015. However, the future evolution of these indicators will be sensitive to the macroeconomic assumptions, particularly exports and the terms of new external financing, as well as government policy. In particular, sound macroeconomic management, further progress with structural reform, and strengthened debt management will be important for debt sustainability.

8. Looking ahead, Guinea's large untapped mining resources offer the potential for a substantial boost in growth and poverty reduction. To ensure an effective exploitation of these resources in which the country reaps an equitable share of the rewards, the government should promote good governance and transparency in the sector. The government should also seek to minimize any financial risks from its participation in the sector that could compromise fiscal and external debt sustainability.

9. The staffs recommend that the Executive Directors of IDA and the IMF approve the completion point for Guinea under the Enhanced HIPC Initiative.

\footnotetext{
${ }^{2}$ This is discussed in Paragraphs 32, 40 and 41.
} 


\section{INTRODUCTION}

1. This paper discusses the Republic of Guinea's progress towards reaching the floating completion point under the Enhanced Heavily Indebted Poor Countries (HIPC) Initiative. In the view of the staffs of the International Development Association (IDA) and the International Monetary Fund (IMF), Guinea has satisfactorily implemented the completion point triggers as formulated in the December 2000 HIPC Decision Point document. ${ }^{1}$ In the view of the two staffs this progress is sufficient for recommending to their respective Boards the approval of the completion point for Guinea under the Enhanced HIPC Initiative.

\section{The Executive Boards of IDA and the IMF declared Guinea to be eligible for} assistance under the Enhanced HIPC Initiative in December 2000. The Executive Boards of IDA and the IMF determined that Guinea had reached the decision point for the Enhanced HIPC Initiative and agreed on the triggers for the floating completion point (Box 5, page 28 of the Decision Point Document). At the decision point, the present value (PV) of debt relief required to reduce the external public debt of Guinea to sustainable levels was estimated at $\$ 545$ million calculated as of end-December 1999. Such relief represented an overall reduction of 31.6 percent of the $\mathrm{PV}$ of all public and publicly-guaranteed external debt as of end-December 1999 after the application of traditional debt relief. At the same time, the two Boards approved interim debt relief to Guinea. IMF interim relief was suspended from March 2004 to November 2007 and from June 2009 to January 2012, because Guinea was not supported under a formal IMF arrangement. ${ }^{2}$ Guinea reached the ceiling for HIPC interim relief provided by IDA of 33 percent of committed debt (in PV terms) on November 15, 2005. Interim relief was resumed in May 2008 when IDA's ceiling was raised to 50 percent. $^{3}$ Guinea's progress towards meeting the requirements for the completion point was impeded by political instability, including a military coup d'état in 2008. Following the election of a civilian government in December 2010, Guinea restarted its efforts to meet the completion point triggers.

3. The paper is organised as follows. Section II assesses Guinea's performance in meeting the requirements for reaching the floating completion point under the enhanced HIPC Initiative. Section III provides an updated debt relief analysis (DRA). Section IV summarises the main conclusions and Section V presents issues for discussion.

\footnotetext{
${ }^{1}$ See "Republic of Guinea: Enhanced Initiative for Heavily Indebted Poor Country - Decision Point Document", IDA/R2000-4, January 10, 2000).

${ }^{2}$ Guinea's performance under IMF-supported programs: a three-year PRGF arrangement was approved in May 2001, but the program went off-track in December 2002 following the completion of the first review and expired in May 2004. A staff-monitored program (SMP) covering April 2005 through March 2006 was satisfactorily implemented but negotiations on a subsequent PRGF-arrangement collapsed amid policy slippages and social unrest. A new three-year PRGF arrangement for July 2007-June 2010 was approved on December 21, 2007. The first review of this arrangement was concluded on July 28, 2008, but the second review could not be completed following the military coup in December 2008 and the arrangement expired in June 2010. An SMP covering 2011 was satisfactorily implemented, which paved the way to a program supported under the Extended Credit Facility, covering 2012-15.
}

${ }^{3}$ Republic of Guinea: Revised Schedule of IDA’s HIPC Debt Relief, IDA/Sec M2007-0712, December 26, 2007. 


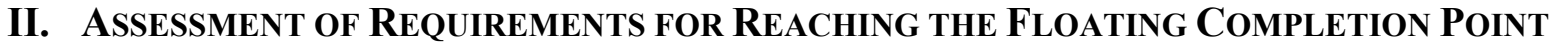

\section{In the view of the staffs of IDA and the IMF, Guinea made sufficient progress for} reaching the floating completion point (Box 1). All but one of the triggers have been met; the remaining trigger (Trigger \#6) has not been fully met but the broad objective was maintained, and the authorities requested a waiver. All key decisions, actions and measures required to fulfil the triggers have been taken, with respect to the preparation of a full Poverty Reduction Strategy Paper (PRSP) and its satisfactory implementation for at least one year (Trigger \#1); improvement of the poverty database and monitoring capacity (Trigger \#2); continued maintenance of macroeconomic stability as evidenced by satisfactory implementation of the PRGF-supported program (Trigger \#3); ${ }^{4}$ develop and take steps to provide an appropriate regulatory framework for microcredit institutions (Trigger \#4); publication of a progress report on the activities of the Anti-Corruption Committee (Trigger \#5); increase in gross enrolment rates for girls and boys in primary schools (Trigger \#7); annual increase in the number of primary school teachers (Trigger \#8); increase in DTP3 vaccination coverage (Trigger \#9); and increase in the percentage of pregnant women receiving prenatal consultations (Trigger \#10).

\section{Progress in meeting triggers was, nonetheless, much slower than initially} anticipated. At the decision point in 2000, the Authorities were aiming to reach the completion point in 2002. However, macroeconomic stabilisation programs and market oriented reforms initiated in the 1990s were halted soon after the Decision Point under pressure of vested interests. The repression of civil and political liberties, combined with widespread corruption, resulted in disastrous development outcomes and frequent urban social unrest. In late 2008, a military junta seized power, which prompted the international community to stop then formal relationship with (and suspend disbursements to) Guinea. Fiscal control was abandoned during 2009-10 and poverty increased. The new government that was established after the first free and fair presidential elections since Guinea's independence in 1958 at end-December 2010 restarted the process toward macroeconomic stabilization and structural reform. As a result, some of the significant development outcomes (e.g. Health and Education) envisaged to be attained two years after the decision point, were only attained a decade later.

\footnotetext{
${ }^{4}$ The Poverty Reduction and Growth Facility (PRGF) has been succeeded by the Extended Credit Facility (ECF).
} 
Box 1. Guinea: Status of Floating Triggers (as of end-July 2012)

\begin{tabular}{|l|}
\hline Triggers \\
\hline Poverty Reduction \\
\hline 1. Preparation of a full PRSP through a participatory \\
process and its satisfactory implementation for one \\
year as evidenced by the Joint Staff Assessment of the \\
country's annual progress report.
\end{tabular}

2. Improvement of the poverty database and monitoring capacity by preparing a living standards measurement survey that establishes poverty lines and indicators based thereon, and establishment of a poverty monitoring system involving key stakeholders.

3. Continued maintenance of macroeconomic stability as evidenced by satisfactory implementation of the PRGF-supported program.

Assessment

Met. Implementation of the PRSP-II issued in 2007 was interrupted by the military coup of December 2008. The Government formed after the presidential election at end-2010 extended the PRSP-II over the 2011-12 period. A full one-year progress report on implementation of the strategy during 2011 was submitted to IDA and the IMF in May 2012. A Joint Staff Advisory Note on the annual progress report, confirming satisfactory implementation of the PRSP during 2011, is being presented to the Boards of IDA and the IMF in parallel with this enhanced HIPC initiative completion point report.

Met. A comprehensive poverty assessment survey was conducted in 2002/3. Thereafter the poverty database was improved and updated. Based on the household survey, 54 poverty indicators were formulated. Two new surveys were conducted in 2007/8 and 2012. The results of the 2012 survey were validated in a meeting including key stakeholders on July 30, 2012.

Met. A PRGF-supported program approved on December 21, 2007 went off-track after the first review. Since 2011, the Government has established a strong track record under the IMF Staff-Monitored Program and under a program supported under the Extended Credit Facility (ECF) for 2012-15, approved by the IMF Board on February 24, 2012. The report on the satisfactory first review of the ECFsupported program is being presented to the Board of the IMF in parallel with this enhanced HIPC Initiative completion point report.

4. Develop and take steps to provide an appropriate Met. A new law was passed by Parliament in November regulatory framework for microcredit institutions.

2005, establishing a regulatory framework for microcredit institutions; and implementing regulations were approved.

\section{Governance and Anticorruption}

5. Make publicly available a one-year progress report (showing resources and activities) of the Anti-Corruption Committee (CNLS).

6. Audit all government procurement contracts over GNF 100 million and publish results of these audits on a quarterly basis.
Met. Activity reports of the CNLS, covering the years 2007-11, have been published, and are accessible on the Government's website (http://www.srp-guinee.org/).

Not completed, but satisfactory progress has been made.

The government commissioned a comprehensive audit of all government contracts over 2002-04 and a final audit report was completed in 2007. A system of quarterly audits based on a representative sample of large government contracts was put in place in 2008. Reports covering 2007, 2008, 2009, 2010, and the first semester of 2011 have been completed. The audited sample represented 70 percent of the public contracts in 2009-10. The audit reports were published (in the Official Journal of the Government of Guinea in May 2012 and the Procurement Gazette). 
Box 1. Guinea: Status of Floating Triggers (as of end-July 2012) (concluded)

\begin{tabular}{|c|c|}
\hline Triggers & Assessment \\
\hline \multicolumn{2}{|l|}{ Education } \\
\hline $\begin{array}{l}\text { 7. Increase the gross enrollment rate for primary } \\
\text { school students from } 56 \text { percent in } 1999 \text { to } \\
62 \text { percent in } 2001 \text { and } 71 \text { percent in } 2002 \text {, of } \\
\text { which the gross enrollment rate of girls should } \\
\text { be } 40 \text { percent in } 1999,51 \text { percent in } 2001 \text { and } \\
61 \text { percent in } 2002 \text {. }\end{array}$ & $\begin{array}{l}\text { Met. Gross enrollment increased significantly after 2002, } \\
\text { reaching } 79 \text { percent in } 2006 \text { and } 80 \text { percent in } 2011 \text {. Gross } \\
\text { enrollment for girls reached } 71 \text { percent in } 2006 \text { and } \\
73 \text { percent in } 2011 \text {. }\end{array}$ \\
\hline $\begin{array}{l}\text { 8. Increase the number of new primary school } \\
\text { teachers hired by at least } 1,500 \text { a year for each } \\
\text { year until the HIPC completion point, from an } \\
\text { estimated base of about } 15,000 \text { primary school } \\
\text { teachers in } 2000 \text {. }\end{array}$ & $\begin{array}{l}\text { Met. On average 1,673 primary school teachers have been } \\
\text { recruited and trained each year from } 2001 \text { through } 2011 \text {. }\end{array}$ \\
\hline \multicolumn{2}{|l|}{ Health } \\
\hline $\begin{array}{l}\text { 9. Increase immunization (DTP } 3 \text { : diphtheria, } \\
\text { tetanus, pertussis) rates for children under } \\
1 \text { year of age, from } 45 \text { percent in } 2000 \text {, to } 50 \\
\text { percent in } 2001 \text {, and to } 55 \text { percent in } 2002 \text {. }\end{array}$ & $\begin{array}{l}\text { Met. Immunization coverage of DPT } 3 \text { reached } 88 \text { percent in } \\
2011 .\end{array}$ \\
\hline $\begin{array}{l}\text { 10. Improve the percentage of pregnant women } \\
\text { benefiting from at least } 1 \text { prenatal consultation } \\
\text { from } 70 \text { percent in } 2000 \text {, to } 80 \text { percent in } 2001 \text {, } \\
\text { and to } 85 \text { percent in } 2002 \text {. }\end{array}$ & $\begin{array}{l}\text { Met. } 88 \text { percent of pregnant women had at least one } \\
\text { ante-natal care consultation in } 2011 \text {. }\end{array}$ \\
\hline
\end{tabular}

\section{A. Poverty Reduction}

\section{Trigger \#1: A full PRSP has been prepared through a participatory process and satisfactorily implemented for one year as evidenced by the Joint Staff Advisory Note on the country's annual progress report.}

6. Staffs consider this trigger to have been met. The political instability which afflicted Guinea during the 2000s thwarted the authorities' efforts to implement its First Poverty Reduction Strategy covering 2002-06 (PRSP-I) issued in December 2001. The Government issued a second PRSP (PRSP-II) covering 2007-10 in August 2007, building on the lessons learnt from the unsuccessful implementation of the PRSP-I. The PRSP-II was discussed by the Boards of the IMF in December 2007 and IDA in January 2008, together with a Joint Staff Advisory Note (JSAN). ${ }^{5}$ In 2010, the authorities decided to extend the implementation of the PRSP-II until end-2012 to offset the negative impact of political instability and external shocks on key development indicators in 2009 and 2010. The extension was adopted by the government in January 2011 and presented to the National Transitional Committee (CNT) in

\footnotetext{
${ }^{5}$ Republic of Guinea: Poverty Reduction Strategy-IDA/SecM2007-489, July 3, 2007.
} 
February 2011. To accelerate implementation of the extended PRSP-II, the government issued President Condé's Priority Action Plan (2011-12) that articulates a strategy for recovery from the crisis period of 2009-10 (which recorded a significant decline in per capita income) and for laying the foundations for sustained growth and development. The Action Plan addresses the serious fiscal and macroeconomic imbalances stemming from the 2009-10 military regime, and details the reforms to be initiated in 2011 and 2012 to improve the investment climate, to promote private entrepreneurship, to facilitate the integration and access of the Guinean private sector to regional markets, to reform the mining code, and to boost agricultural production.

\section{The PRSP-II and its extended version were prepared through extensive and} continuing public consultations designed to highlight priority actions needed to improve living standards, particularly in the rural areas, and to obtain stakeholder buy-in to the development strategy. ${ }^{6}$ The overarching objective of the PRSP-II and its extension is to accelerate economic growth and make progress toward the Millennium Development Goals (MDG). The main pillars of the strategy include: (i) improving governance; (ii) accelerating growth and increasing employment opportunities while further stabilizing the economy; and (iii) improving access to basic services. The strategy was accompanied by an emergency investment program to re-launch economic activities and programs to diversify the economy from overdependence on extractive industries. Such a program was made financeable by the full re-engagement of IDA, following the clearance of arrears to IDA in March 2011.

\section{A one-year Progress Report (PR) covering 2011 was prepared by the authorities} and discussed with development partners in April 2012. As discussed in the Joint Staff Advisory Note (JSAN) accompanying this report, ${ }^{7}$ the PR shows that 2011 was a watershed year in terms of the political environment, policy implementation and development outcomes. Major progress was made in restoring political stability and democratic governance, reforming the security sector and containing military expenditures, consultations on justice reforms, and in the fight against corruption, especially through procurement audits and reforms. A significant reduction of fiscal and macroeconomic imbalances was also achieved. The government's program was strongly supported by the donor community. As a result of sustained implementation of reforms, Guinea's growth rate increased markedly, inflation declined, foreign exchange reserves increased, and the exchange rate stabilized. ${ }^{8}$ The delivery of social services was improved, which is a good step towards poverty reduction. The PR also highlights the numerous challenges facing Guinea in the near future, including in particular a demanding agenda for improvements in key areas such as the extractive industries and their possible effect on the economy, human development, infrastructure, governance and institution building. These are the key areas that the authorities aim to cover in the next PRSP (PRSP-III), scheduled for completion in late 2012. Progress in these areas will be supported by continued progress in the area of peace and security.

\footnotetext{
${ }^{6}$ In particular, regional consultations were held in two major regional centers during January-February 2011 in Kindia (covering the Southern part of the country) and Kankan (covering the Northern part of the country).

${ }^{7}$ Joint Staff Advisory Note on the Extended Poverty Reduction Strategy Paper 201112 and the 2011 Progress Report, IMF Country Report www.imf.org, August 30, 2012.

${ }^{8}$ Recent macroeconomic and financial developments are discussed in the report of the IMF staff on the first review under the ECF-arrangement.
} 
Trigger \#2: Improvement of the poverty database and monitoring capacity by preparing a living standards measurement survey which will include establishment of poverty lines and indicators based thereon, and establishment of a poverty monitoring system involving key stakeholders.

9. Staffs consider this trigger to have been met. Two household surveys carried out in 2002/03 (Enquête Intégrée de Base pour l'Evaluation de la Pauvreté, EIBEP) and in 2007/08 (using the Core Welfare Indicators Questionnaire Survey, CWIQ) were used to establish poverty lines and poverty profiles for Guinea, and lay the foundations for improved poverty monitoring and evaluation. To strengthen further the poverty data base, the Government launched two additional surveys: the Multiple Indicators Cluster Survey (MICS) 2007/08, and the Demographic and Health Survey (DHS) in 2008. In 2012, a new household survey was conducted, using the CWIQ methodology and including an expenditure module. A participatory Poverty Assessment (PPA) survey was also conducted in January-February 2011. The PPA complemented the other available surveys by providing qualitative information on poverty profiles and households' coping strategies.

10. The various surveys carried out since 2000 have strengthened the capacity of the National Statistical Office (NSO) to monitor poverty and evaluate policy outcomes. Poverty monitoring is under the responsibility of a Committee established at the Poverty Reduction Strategy Secretariat headed by the Director of the NSO. The Committee, which meets once a month, has spearheaded the Government's efforts in preparing the 2011 PRSP progress report and liaising with development partners on various statistical issues. The NSO has completed preparatory work on a Decennial Population Census slated for late 2012. With assistance from the World Bank, a poverty assessment report has been prepared and disseminated in the country in July 2012, and follow up work on more micro dimensions of poverty are scheduled for the next 12 months.

11. Nevertheless, the latest data show an aggravation of poverty during the last decade. The household surveys conducted using the CWIQ methodology suggest significant increases in poverty rates from 49 percent in 2002 to 53 percent in 2007 and to 55 percent in 2012. Further disaggregation of the 2012 CWIQ survey by gender shows that the literacy rate for women is 22.8 percent compared with 47.2 percent for men. However, the primary school enrollment rate for girls is 55.4 percent compared with 60 percent for boys. The results of the CWIQ survey provides solid analytical basis for poverty monitoring and evaluation.

\section{B. Macroeconomic and Structural Reforms}

Trigger \#3: Continued maintenance of macroeconomic stability as evidenced by satisfactory implementation of the PRGF-supported program.

12. Staffs consider this trigger to have been met. Following episodes of large economic imbalances after the 2000 decision point, the government has implemented strong measures to restore macroeconomic stability since early-2011. The economy has been periodically 
destabilized by a combination of external and internal factors since the 2000 Decision Point. Regional political instability caused a massive influx of refugees in 2002 . The country experienced adverse terms-of-trade shocks, particularly in 2003-05, as prices for its mineral exports (accounting for more than 90 percent of overall exports) declined. Persistent social upheaval and bad governance led to episodes of policy slippage, high inflation, depletion of international reserves, and exchange rate depreciation between 2002 and 2010. Stabilization policies started in 2007 were short-lived as the military coup at end-2008 brought back large economic imbalances: the budget deficit and central bank advances reached 1 percent of GDP per month during 2009-10; reserves coverage fell to less than one month of imports; the market exchange rate depreciated sharply and inflation increased to over 20 percent (year-on-year) by end-2010; and Guinea accumulated external arrears to bilateral and multilateral creditors, including IDA. In early-2011, the newly elected government took corrective actions to address the imbalances. Under the Staff Monitored Program (SMP) with the IMF, covering 2011, fiscal control was restored; monetary policy was tightened, and macro-critical structural reforms were launched; and external arrears to IDA and other multilateral creditors were cleared. The satisfactory performance under the SMP paved the way for a program supported under the IMF's Extended Credit Facility (ECF) covering the period 2012-15, approved by the IMF's executive Board on February 24, 2012. ${ }^{9}$

\section{Fiscal performance has been satisfactory since 2011, anchored on cash-based}

expenditure management. In 2011, fiscal adjustment was stronger than programmed. The basic fiscal deficit was reduced from about 13 percent of GDP in 2010 to less than 2 percent of GDP in 2011. Several revenue measures were implemented but the adjustment came mainly from the elimination of low-priority spending and the suspension of large non-competitively awarded procurement contracts for goods and services and investment projects committed during 2009-10. Bank financing of the treasury was virtually stopped with the enforcement of cash-based management of the budget; the receipt of large exceptional mining revenue in May 2011 allowed the start of an increase in macro-critical public investment, especially in the electricity sector. Fiscal discipline continued during the first half of 2012, under the ECF-supported program. The revenue target for end-June 2012 was met despite mounting fuel subsidies as the authorities decided to keep domestic prices unchanged as import prices increased. Expenditure was largely below the programmed level as the authorities tried to make room for a large expenditure overflow from 2011 and to address the delay in expected new exceptional mining revenue. Budget execution also benefitted from the retirement of 4,000 military personnel in 2011 . The basic fiscal deficit was much below the end-June program target and all quantitative performance criteria (adjusted for the shortfall in exceptional revenue) under the ECF-supported program for end-June 2012 were met with the exception of that on the accumulation of external debt service arrears, for which staff supports that a waiver be granted.

\footnotetext{
${ }^{9}$ Guinea's performance under IMF-supported programs: a three-year PRGF arrangement was approved in May 2001, but the program went off-track in December 2002 following the completion of the first review and expired in May 2004. A staff-monitored program (SMP) covering April 2005 through March 2006 was satisfactorily implemented but negotiations on a subsequent PRGF-arrangement collapsed amid policy slippages and social unrest. A new three-year PRGF arrangement for July 2007-June 2010 was approved on December 21, 2007. The first review of this arrangement was concluded on July 28, 2008, but the second review could not be completed following the military coup in December 2008 and the arrangement expired in June 2010.
} 
14. Monetary policy was appropriately tightened, aimed at reducing excess liquidity.

The policy slippages in 2009-10 created large excess liquidity, high inflation, and a substantial premium in the market exchange rate over the official rate. In 2011, the central bank raised the policy rate from 16.75 to 22 percent and the reserve requirement from 9.5 to 22 percent. Regulations on foreign exchange bureaus were improved and the central bank started weekly foreign exchange auctions in March 2011. As a result, inflation declined from 21 percent at end-2010 to 15 percent in June 2012 (year-on-year); the exchange rate stabilized and the market exchange rate premium shrunk to below 2 percent in the first half of 2012. In April 2012, the government reached agreement on a rescheduling of external debt with Paris Club creditors and the authorities are seeking debt relief on comparable terms from private and other bilateral creditors.

\section{Good progress has also been made on structural reforms since 2011. The new} mining code adopted in September 2011 is expected to improve transparency in the sector and raise government revenue; implementation regulations of this new mining code are being prepared, with World Bank and IMF support. Strategic and technical committees were set up to review and renegotiate existing mining contracts in line with the new code to ensure that the government obtains a fair share of revenue from Guinea's abundant mineral resources. A Special Investment Fund was created to receive exceptional mining revenue and ensure its transparent and efficient use. Based on an action plan agreed with development partners in early 2012, the authorities have started to reform the electricity sector, aimed at restoring financial viability of the state-owned electricity company and increasing supply. The agricultural sector received strong support, through the government's facilitation of access to fertilizers and equipment. The on-going reforms in the agricultural and electricity sectors are expected to reduce budget subsidies in the near future. Reforms to improve the business climate are under way, including the creation of an investment promotion agency in 2011 and a revision of the Investment Code by mid-2013.

\section{Growth rebounded in 2011, supported by expanding agricultural production,} growing investment in the mining sector, and improved confidence in the business environment. The growth rate of real GDP averaged 2.8 percent over 2001-08, down from 4.4 percent in the previous decade. Following the military coup, growth dropped below 1 percent in 2009-10. It recovered to almost 4 percent in 2011 and is expected to reach 4.8 percent in 2012, despite the difficult world economic environment. Guinea's external position strengthened in 2011; the external current account deficit improved by 3.5 percent of GDP, and the level of gross foreign exchange reserves increased to the equivalent of 4.5 months of imports. ${ }^{10}$

\section{While Guinea has made strong progress in macroeconomic management since} early-2011, some challenges remain, which the government is addressing under its reform programs. As in other areas, there are serious capacity constraints in key institutions such as the Central Bank and the Ministry of Economy and Finance. Public financial management needs

\footnotetext{
${ }^{10}$ The high reserve position was mainly due to exceptional mining revenue; reserves are projected to decrease as this revenue will be gradually used, but are expected to be buttressed by the large iron ore production in the middle of this decade.
} 
further improvement, including reforms of the legal framework, the ability to produce a real-time situation in the expenditure chain, and to secure an accurate flow of information between the Treasury, Central Bank, and revenue collecting agencies. The central bank's systems for accounting and the preparation of monetary statistics need urgent improvement. To encourage broad-based growth and to ensure that an expected mining boom by the middle of the decade results in wide-spread poverty reduction, Guinea will need to address key bottlenecks for economic activity. These include governance, such as reform and strengthening of the judiciary, rebuilding infrastructure, including in roads and electricity; and, more generally, actions to improve the business climate. Strong agricultural sector polices would provide jobs and income to a large part of the population.

\section{Trigger \#4: Develop and take steps to provide an appropriate regulatory framework for microcredit institutions.}

18. Staffs consider this trigger to have been met. A new law was passed by Parliament in November 2005 establishing a regulatory framework for micro credit institutions. ${ }^{11}$ Thereafter implementing regulations were prepared and approved in 2007 and over the next two years training provided to the supervisors with the assistance of the World Bank and the African Regional Technical Assistance Center (AFRITAC) under a multi-donor trust fund. Additional implementing regulation was enacted at the beginning of 2012. As covering the licensing of micro-credit institutions, supervision, sanctions and liquidation, the 2005 law and its implementing regulations constitute significant and necessary steps to provide an appropriate regulatory framework for microcredit institutions.

\section{The Directorate for Supervision of Micro-Finance Institutions (MFI) at the Central}

Bank was charged in 2006 to implement these new regulations. It has since conducted periodic on and off-site supervision of MFIs and issues regular reports. Since 2005 the sector has experienced net growth and counts today 16 micro finance institutions with 432 offices of which only 7 percent in Conakry. Nonetheless, the effective implementation of supervision is hampered by the low quality of information provided by the MFIs. Many MFIs do not have adequate management information systems and their data provision to the supervisor is lacking important information. Furthermore, the Central Bank in its 2011 report on supervision of MFIs estimates that many MFIs might not be profitable and do not meet required prudential indicators, but sanctions have not yet been imposed. The World Bank's Finance and Private Sector Unit is exploring the possibility of providing support to strengthen the capacity of the Directorate for supervision of MFI. The Government also established a new Micro Finance Authority, demonstrating the importance the Government gives to the sector and to promote access to credit for micro entrepreneurs.

\footnotetext{
${ }^{11}$ République de Guinée. (La Banque centrale de la République de Guinée), Loi sur la MicrofinanceL/2005/020/AN November, 2005.
} 
Table 1. Guinea: Selected Economic and Financial Indicators, 2008-16

\begin{tabular}{|c|c|c|c|c|c|c|c|c|c|}
\hline & 2008 & 2009 & 2010 & $\begin{array}{r}2011 \\
\text { Est. }\end{array}$ & $\begin{array}{c}2012 \\
\text { Proj. }\end{array}$ & $\begin{array}{l}2013 \\
\text { Proj. }\end{array}$ & $\begin{array}{c}2014 \\
\text { Proj. }\end{array}$ & $\begin{array}{c}2015 \\
\text { Proj. }\end{array}$ & $\begin{array}{l}2016 \\
\text { Proj. }\end{array}$ \\
\hline & \multicolumn{9}{|c|}{ (Annual percentage change, unless otherwise indicated) } \\
\hline \multicolumn{10}{|l|}{ National accounts and prices } \\
\hline GDP at constant prices & 4.9 & -0.3 & 1.9 & 3.9 & 4.8 & 5.0 & 5.2 & 19.9 & 19.7 \\
\hline GDP deflator & 14.1 & 6.8 & 20.2 & 19.6 & 14.7 & 6.3 & 7.4 & 5.2 & 5.0 \\
\hline GDP at market prices & 19.7 & 6.5 & 22.5 & 24.3 & 20.2 & 11.7 & 13.0 & 26.1 & 25.7 \\
\hline \multicolumn{10}{|l|}{ Consumer prices } \\
\hline Average & 18.4 & 4.7 & 15.5 & 21.4 & 14.7 & 10.3 & 7.3 & 6.0 & 5.9 \\
\hline End of Period & 13.5 & 7.9 & 20.8 & 19.0 & 12.0 & 8.7 & 6.2 & 5.9 & 5.9 \\
\hline \multicolumn{10}{|l|}{ External sector } \\
\hline Exports goods \& services (in US\$ terms) & 32.0 & -22.1 & 13.6 & 12.1 & 3.0 & 2.2 & 5.8 & 77.5 & 53.3 \\
\hline Imports goods \& services (in US\$ terms) & 19.6 & -21.2 & 26.2 & 38.3 & 48.3 & 7.2 & 1.7 & 13.4 & 8.8 \\
\hline \multicolumn{10}{|l|}{ Average effective exchange rate (depreciation - ) } \\
\hline Nominal index & -13.4 & 3.3 & -17.0 & -18.1 & $\ldots$ & $\ldots$ & $\ldots$ & $\ldots$ & $\ldots$ \\
\hline Real index & -2.2 & 7.1 & -8.2 & -3.2 & $\ldots$ & $\ldots$ & $\ldots$ & $\ldots$ & $\ldots$ \\
\hline \multicolumn{10}{|l|}{ Money and credit } \\
\hline Net Foreign Assets 1/ & 14.3 & 4.7 & -5.5 & 40.1 & -11.6 & -1.2 & $\ldots$ & $\ldots$ & $\ldots$ \\
\hline Net Domestic Assets 1/ & 24.7 & 21.2 & 79.9 & -30.7 & 16.9 & 11.4 & $\ldots$ & $\ldots$ & $\ldots$ \\
\hline Net Claims on government $1 /$ & 20.8 & 28.7 & 70.2 & -44.8 & 17.7 & 7.6 & $\ldots$ & $\ldots$ & $\ldots$ \\
\hline Credit to nongovernment sector $1 /$ & 1.9 & 3.1 & 8.9 & 15.0 & 2.0 & 7.0 & $\ldots$ & $\ldots$ & $\ldots$ \\
\hline Reserve Money & 13.8 & 81.7 & 73.0 & -4.9 & -6.2 & 8.3 & $\ldots$ & $\ldots$ & $\ldots$ \\
\hline Broad money (M2) & 39.0 & 25.9 & 74.4 & 9.4 & 5.3 & 10.2 & $\ldots$ & $\ldots$ & $\ldots$ \\
\hline \multirow[t]{2}{*}{ Interest rate (short term T-bill) } & 21.5 & 15.0 & 13.0 & 13.0 & $\ldots$ & $\ldots$ & $\ldots$ & $\ldots$ & $\ldots$ \\
\hline & \multicolumn{9}{|c|}{ (Percent of GDP) } \\
\hline \multicolumn{10}{|l|}{ Central government finances 2/ } \\
\hline Total revenue and grants & 16.1 & 16.5 & 15.7 & 20.3 & 22.9 & 24.0 & 24.9 & 27.5 & 28.2 \\
\hline Revenue & 15.6 & 16.2 & 15.3 & 16.8 & 19.2 & 20.2 & 20.8 & 24.1 & 26.3 \\
\hline Of which: nonmining revenue & 12.1 & 12.9 & 11.5 & 13.0 & 15.0 & 16.2 & 16.4 & 16.7 & 17.9 \\
\hline Grants & 0.5 & 0.4 & 0.4 & 3.4 & 3.7 & 3.8 & 4.1 & 3.4 & 1.9 \\
\hline Total expenditure and net lending & 17.5 & 23.7 & 29.7 & 21.5 & 28.3 & 26.6 & 26.2 & 28.4 & 29.7 \\
\hline Current expenditure & 13.4 & 16.5 & 20.5 & 16.3 & 15.8 & 16.3 & 15.6 & 15.2 & 15.0 \\
\hline Of which: interest payments & 2.6 & 2.1 & 2.0 & 2.0 & 1.5 & 1.4 & 1.3 & 1.2 & 1.1 \\
\hline Capital expenditure and net lending & 4.0 & 7.2 & 9.1 & 5.2 & 12.4 & 10.3 & 10.5 & 13.2 & 14.6 \\
\hline \multicolumn{10}{|l|}{ Overall budget balance $2 /$} \\
\hline Including grants (commitment) & -1.3 & -7.1 & -14.0 & -1.3 & -5.3 & -2.6 & -1.3 & -0.9 & -1.5 \\
\hline Excluding grants (commitment) & -1.8 & -7.5 & -14.4 & -4.7 & -9.1 & -6.4 & -5.4 & -4.3 & -3.4 \\
\hline Basic fiscal balance & 1.6 & -5.6 & -12.6 & -1.6 & -3.6 & -1.4 & -0.6 & -0.6 & 0.6 \\
\hline \multicolumn{10}{|l|}{ National accounts } \\
\hline Gross capital formation & 17.5 & 11.4 & 10.6 & 17.6 & 37.3 & 44.1 & 43.9 & 33.7 & 19.1 \\
\hline Savings & 7.2 & 1.6 & -1.8 & 1.3 & -1.7 & 4.4 & 4.8 & 12.4 & 14.2 \\
\hline \multicolumn{10}{|l|}{ Current account balance } \\
\hline Including official transfers & -10.3 & -9.9 & -12.4 & -16.3 & -39.0 & -39.7 & -39.2 & -21.3 & -5.0 \\
\hline Excluding official transfers & -10.8 & -9.9 & -12.4 & -18.6 & -39.8 & -40.7 & -40.3 & -22.3 & -5.0 \\
\hline \multirow[t]{2}{*}{ Overall balance of payments } & -0.9 & 5.3 & -3.6 & 10.1 & -8.4 & -4.0 & -0.1 & 2.4 & 1.4 \\
\hline & \multicolumn{9}{|c|}{ (US\$ millions, unless otherwise indicated) } \\
\hline \multicolumn{10}{|l|}{ Memorandum Items: } \\
\hline Exports, goods \& services & $1,578.1$ & $1,229.9$ & $1,397.3$ & $1,566.0$ & $1,613.7$ & $1,648.5$ & $1,743.6$ & $3,095.1$ & $4,745.7$ \\
\hline Imports, goods \& services & $1,810.4$ & $1,427.2$ & $1,800.4$ & $2,490.8$ & $3,693.8$ & $3,958.3$ & $4,026.6$ & $4,564.8$ & $4,966.0$ \\
\hline Overall balance of payments & -42.4 & 245.9 & -177.8 & 520.6 & -481.3 & -247.4 & -6.1 & 179.1 & 124.7 \\
\hline Net foreign assets (central bank) & -14.1 & 97.9 & 39.6 & 637.6 & 265.7 & 214.8 & 260.8 & 460.6 & 577.7 \\
\hline Gross available reserves (months of imports) $3 /$ & 0.6 & 0.8 & 0.7 & 4.6 & 2.9 & 2.9 & 3.0 & 3.1 & 3.7 \\
\hline Nominal GDP (GNF billions) & 20,780 & 22,133 & 27,118 & 33,697 & 40,494 & 45,219 & 51,114 & 64,439 & 80,983 \\
\hline
\end{tabular}

Sources: Guinean authorities; and Fund staff estimates and projections.

$1 /$ In percent of the broad money stock at the beginning of the period.

2/ The one-off mining revenue in 2011 is included under non-bank financing.

$3 /$ In months of imports excluding imports for large foreign-financed mining projects. 


\section{Governance and Anti-Corruption Actions}

\section{Trigger \#5: Make publicly available a one-year progress report (showing resources and activities) of the Anticorruption Committee.}

20. Staffs consider this trigger to have been met. Reports of the Anti-Corruption Agency, l'Agence Nationale de Lutte contre la Corruption (ANLC), were published in 2007, 2008, 2009, 2010, and 2011. They provide details on resources and activities, and are available on the government's websites and the United Nations Development Program (UNDP) local office website. ${ }^{12}$ The 2011 report highlighted Guinea's signing, ratification and promulgation of the United Nations and African Union conventions against corruption and the ECOWAS Anti-Corruption Protocol. The report also provided details on the setting up of an office within the ANLC and a telephone hotline to receive complaints from the public regarding the misuse of government resources. A total of 58 complaints were investigated in 2011.

\section{The government has taken several actions to improve governance and reduce} corruption over recent years. These include major public finance management controls (procurement, treasury single account, cash-based budgeting), a biometric census of civil servants and the military (leading to the removal from the payroll of ghost workers and public sector employees having reached the retirement age), and the establishment of a legal and institutional framework for managing windfall mining resources, along with the reactivation of Guinea's membership to the Extractive Industries Transparency Initiative, from which it had been suspended during the period of military rule. It also includes a survey on the perception of corruption in 2003, training for ANLC staff and journalists on economic governance, and the holding of public workshops on corruption.

\section{Trigger \#6: Audit all government procurement contracts over GNF 100 million and publish results of these audits on a quarterly basis.}

\section{Staffs consider good progress has been made in fulfilling this trigger. Guinea has} gradually improved the auditing of public procurement contracts, albeit not as quickly as was envisaged at the decision point. For lack of resources and various internal disruptions, the authorities had difficulties initially in setting up quarterly audits of all procurement contracts over GNF 100 million (\$53.2 million equivalent in 2000). Comprehensive audits covering large contracts for 2002-04 were launched with delays, and the related audit report was presented only in 2007. Based on this experience, and in line with best international practice, a less ambitious but more flexible and practical system of quarterly audits, covering a representative sample of large contracts, was formalized using Guinea's own oversight institutions. This system was implemented starting in 2008. The first report, covering 13 contracts comprising 20 percent of the procurement contracts of more than GNF 100 million signed in the first quarter of 2007, was published in October 2008. Reports on audits of contracts signed in 2008

\footnotetext{
${ }^{12}$ Government's website: Secretariat Permanent de la Strategie de Reduction de la Pauvrete www.srp-guinee.org; Institut National de la Statistique www.stat-guinee.org; UNDP local office website: www.undp.org/htlm/gv.htlm.
} 
and the first six months of 2009 have also been completed. The change resulted in an improvement in the completion and publication of audits while the main objective of improving the public procurement process was achieved; in light of this, staffs of the IDA and the IMF support the authorities' request for a waiver for not having audited all procurement contracts over GNF 100 million.

\section{As part of the process of re-engagement with IDA in 2011, the Government} decisively strengthened audits of public contracts and broadened coverage. Soon after the presidential elections, the Government froze all public contracts signed in the second half of 2009 and in 2010 (for a total of US\$2.2 billion, or 50 percent of GDP) by the military junta, and launched an audit with the help of auditors from the French Supreme External Audit Institution. The last audit, covering the first half of 2011, was completed by the Government's General Inspection of Finance (Inspection Generale des Finances) in February 2012 and published in May 2012. All the audit reports have been published in the government's official gazette. ${ }^{13}$ These audits identified important weaknesses in past procurement practices and management capacity. Procurement contracts which were signed in 2009-10 in violation of the Public Procurement Code were frozen and are being reviewed by a newly established contract regulatory agency (Commission de Réglement des Marchés Publics), while those for which execution had not begun have been canceled. In this context, a new Procurement Law has been prepared with support from the World Bank, and validated during a national workshop in September 2011. The new law is being further revised for submission to the National Transitional Council for approval in 2012. The freeze or cancellation of numerous large irregularly awarded contracts contributed to reducing fiscal imbalances and to restoring macro-economic stability, while allowing confidence in public financial management capacity, and ultimately, in Government accountability to be rebuilt.

\section{Education}

Trigger \#7: Increase the gross enrollment rate for primary school students from 56 percent in 1999 to 62 percent in 2001 and 71 percent in 2002, of which the gross enrollment rate of girls should be 40 percent in 1999, 51 percent in 2001 and 61 percent in 2002.

24. Staffs consider this trigger to have been met. Significant progress has been made in primary school attendance, including for girls, albeit not as quickly as was envisaged at the decision point. Gross enrollment rates for primary school students and for girls reached 80 and 73 percent, respectively, in 2011. Progress was also achieved with completion rates in primary education, which increased from 32 percent in 2000 to 59 percent in 2011.

25. However, important challenges remain. Between 2006/07 and 2011 the gross enrollment rates at primary level increased only by one percentage point from 79 to 80 percent.

\footnotetext{
${ }^{13}$ Official Gazette of the Republic of Guinea, « Special Edition of the Reports of Quarterly Public Procurement Contracts », May 2012.
} 
The access rate to the first grade of primary school stands at 83 percent (with 77 percent for girls) in 2011 putting Guinea below the sub-regional average; the access rate is particularly low for girls. Access to and the quality of primary education, especially in rural areas, remains low because of a lack of qualified teachers, high direct and indirect costs especially for those from the poorest quintiles as well as insufficient supply of services in the poorest areas, requiring sustained efforts. The World Bank's Social Safety Net Project (approved by the IDA Board in June 2012) will provide added impetus to the Government's efforts, especially girls' education, through its monetary transfer component.

\section{The results in primary education are raising demand for other levels of education.}

Tertiary education in Guinea is facing many challenges, including: (i) a lack of qualified teachers, and a ratio of one teacher for about 100 students, (ii) a lack of minimum equipment, (iii) low penetration of ICT, (iv) mismatch between training (content and quality) and the needs of the labor market and businesses, and (v) an inefficient public private partnership. Hence, post-basic education should become a policy focus in the medium term.

\section{Trigger \#8: Increase the number of new primary school teachers hired by at least 1,500 a year for each year until the HIPC completion point, from an estimated base of about 15,000 primary school teachers in 2000.}

27. Staffs consider this trigger to have been met. Ambitious programs have been implemented in education. Since the decision point, the government has increased the number of qualified primary school teachers by more than 1,500 a year, thus meeting the completion point trigger, and over 12,000 classrooms have been built. These efforts have been made possible through external financing for the most part including programs to expand infrastructure, train teachers, and supply school materials. Although the education sector has one of the largest ministerial budgets (19\% of the national budget's recurrent expenditures or 2.3 percent of GDP spent on education), most of the funding covers personnel salaries.

28. Education has received considerable support from donors, including IDA. Guinea joined the Education for All-Fast Track Initiative (EFA-FTI) in 2003. Through this global education initiative, a $\$ 64$ million program ( $\$ 40$ million under the supervision of the World Bank and \$24 million under UNICEF) is currently being implemented in support of a comprehensive education sector reform strategy for 2009-12. The objectives are to increase access to education, improve its quality, and strengthen the delivery of decentralized education services, especially in disadvantaged rural areas. Reforms in the sector include the provision of incentives for teachers assigned to rural areas, stricter control of the Ministry of Education's payroll through improved human resource and public expenditure management, provision of resources to schools and deconcentrated areas, and other measures to improve the efficiency and quality of education programs. The policies towards teacher recruitment have now shifted from an emphasis on quantity (i.e. number of teachers to be recruited as defined by HIPC) towards the promotion of teacher quality and enhanced accountability in their performance. It will also be important at this stage to promote higher domestic spending effort in education overall, and basic education in particular. 


\section{E. Health}

Trigger \#9: Increase immunization rates for children under one year of age for DTP3 (diphtheria, tetanus and pertussis) from 45 percent in 2000, to 50 percent in 2001, and to 55 percent in 2002.

29. Staffs consider this trigger to have been met. Since 2000, with assistance from the World Bank and the World Health Organization, the Guinean authorities have been implementing a strategy to lower infant mortality through routine immunization of babies, based heavily on two types of campaigns: (i) a nationwide public awareness campaign regarding the availability of immunization for all children aged 9 months and above; and (ii) campaigns promoting follow-up immunization for young children every three to four years. In 2005, the government adopted a ten-year health sector strategy and prepared a detailed five-year development plan (covering the period 2005-10). The objective of the Ministry of Health's Five Year Plan was to improve the health status of the population while reducing inequities with a special focus on the most urgent needs (maternal and child health). Nationwide vaccination campaigns have significantly extended immunization coverage for the population, with DPT3 coverage reaching 88 percent over 2008-11, compared with the completion point target of 55 percent. Nevertheless, these efforts need to be sustained and accelerated over time to avoid a possible reversal in immunization rates as demand for it stagnates.

\section{Trigger \#10: Improve the percentage of pregnant women benefitting from at least one prenatal consultation from 70 percent in 2000, to 80 percent in 2001, and 85 percent in 2002.}

30. Staffs consider this trigger to have been met. The government has made major efforts to improve maternal health and reduce maternal mortality. It has increased the coverage of prenatal visits, raising the percentage of pregnant women who receive at least one prenatal consultation to almost 90 percent in 2011. Besides, in 2011, almost 11,000 women were granted free cesarean treatment in public dispensaries, which were well supplied with necessary equipment and medicines. However, the financial sustainability of these programs (and their expansion to cover the last 10 percent of women not receiving prenatal visits) remains uncertain without adequate financing identified in the budget. With funding support from the EU, the Ministry of Health in 2011 conducted a review of the 10-year development plan (2005-15) in preparation of a new national plan encompassing the Priority Action Health program of newly elected President Alpha Conde. The implementation of the new national plan is being supported by the World Bank, the Global Fund, several United Nations agencies and international and national NGOs

\section{UPDATEd DEbT RELIEF AND SUSTAINABILITY ANALYSIS}

\section{A. Revision of Data Reconciliation as of the Decision Point}

31. The stock of HIPC-eligible external debt in present value (PV) terms at end-1999 was revised upward from the decision point, following the debt reconciliation exercise. 
The staffs of IDA and the IMF, together with the Guinean authorities, have reviewed the stock of debt at the end of December 1999 presented in the decision point document against recent creditor information. As a result, the nominal stock as of end-1999 has increased by $\$ 44.3$ million from $\$ 3,375$ million to $\$ 3,419$ million (Figure A1 and Table A2); and the PV of debt after traditional debt relief has been revised upward by $\$ 38.4$ million, from $\$ 1,727$ million to $\$ 1,766$ million. About half of this increase is attributable to revisions in the PV of debt owed to multilateral creditors and the rest to bilateral creditors.

- Multilateral creditors. At end-1999, the nominal stock of debt owed to multilaterals has decreased by $\$ 4.2$ million to $\$ 1,805.8$ million, and the PV of debt has increased by $\$ 18.8$ million to $\$ 1,058$ million. The PV of debt owed to the African Development Bank (AfDB) Group has increased by $\$ 22.1$ million, mainly because the discount factors applied were revised. ${ }^{14}$ In addition, European Union (EU) loans administered by IDA amounting to $\$ 2.7$ million in nominal terms or $\$ 1.5$ million in PV terms have been reclassified as bilateral. ${ }^{15}$ Estimates of the PV of debt owed to the Islamic Development Bank (IsDB) and the OPEC Fund for International Development (OFID) ${ }^{16}$ have been marginally revised due to revisions in loan terms.

- $\quad$ Paris Club creditors. The PV of debt to Paris Club creditors after traditional debt relief has been revised upward from $\$ 482$ million to $\$ 520$ million, mainly due to new information received from some creditors on the nominal stock of debt and loan details. There have been significant increases in the PV of debt to Japan, and to a lesser extent to the United States of America and Norway, and marginal increases for Belgium, Italy, and Spain. Estimates have been revised downward for the PV of debt to France. A small increase is attributable to the fact that EU loans administered by IDA are now treated as loans from Paris Club creditors.

- Other official bilateral creditors. The PV of the stock of debt owed to other official bilateral creditors has decreased from $\$ 198.3$ million to $\$ 180.3$ million mainly due to the reclassification of loans.

\footnotetext{
${ }^{14}$ The estimate of the PV of debt owed to the AfDB Group at the Decision Point was based on the discount rate applicable for the SDR, which did not appropriately reflect the currency composition of the loans disbursed by the AfDB Group. HIPC Initiative methodology requires application of currency-specific discount factors.

${ }^{15}$ European Union loans administered by IDA were classified as multilateral at the Decision Point. In February 2005, the Commission of the European Union, after consultation with its member states, notified staff that these loans should be reclassified as bilateral to reflect correct ownership status.

${ }^{16}$ A fund established by member countries of the Organization of the Petroleum Exporting Countries (OPEC).
} 
Estimates of exports of goods and services used to evaluate HIPC assistance at the decision point have also been revised downward from an annual average of \$788 million for 1997-99 to \$751 million. ${ }^{17}$

\section{B. Revision of HIPC Assistance and Status of Creditor Participation}

32. As a result of the change in the $P V$ of debt as well as in the export data, the required HIPC assistance in end-1999 PV terms to reduce the PV of debt to exports to 150 percent has been revised upward by $\$ 93.7$ million from $\$ 545.4$ million estimated at the decision point to $\$ \mathbf{6 3 9 . 2}$ million. Correspondingly, the common reduction factor has increased from 31.6 percent to 36.2 percent (Table A4). ${ }^{18}$

33. At the completion point, Guinea has received financing assurances of participation in the Enhanced HIPC Initiative from creditors accounting for 97.5 percent of the PV of HIPC assistance estimated at the Decision Point (Table A11). Multilateral creditors representing 99.6 percent of the PV of multilateral HIPC assistance and bilateral creditors accounting for 95.4 percent of the PV of bilateral and commercial assistance have provided financing assurances. Several multilateral creditors and all Paris Club creditors have provided interim assistance. Some non-Paris Club creditors have already provided their debt relief through stock-of-debt cancellation. Most multilateral and all Paris Club creditors have confirmed their participation. The authorities are working toward reaching agreements with all remaining creditors.

\section{Multilateral creditors}

34. All but one of the multilateral creditors have committed to provide their full share of assistance to Guinea under the Enhanced HIPC Initiative. ${ }^{19}$ The revised assistance from multilateral creditors amounts to $\$ 383$ million in end-1999 PV terms, constituting 60 percent of total HIPC assistance. IDA, the IMF, the AfDB Group, the European Investment Bank (EIB), and the EU provided interim assistance in the form of debt service reduction; the Arab Bank for Economic Development in Africa (BADEA), the IsDB and OFID offered debt rescheduling and refinancing at more concessional terms during the interim period. Total relief provided during the interim period amounts to $\$ 138.6$ million in end-1999 PV terms, corresponding to 36 percent of total HIPC assistance from multilateral creditors.

\footnotetext{
${ }^{17}$ Data revisions were reported to the Board as background information to the 2002, 2003, and 2004 Article IV Consultations.

${ }^{18}$ In accordance with the "Information Reporting in the Context of HIPC Initiative Assistance", approved by the members of the Executive Board of the IMF and IDA (IDA/SecM2002-0131), March 4, 2002, Guinea qualifies for an upward revision of assistance.

${ }^{19}$ The Bank for Investment and Development (EBID) of the Economic Community of West African States (ECOWAS), representing 0.4 percent of the total PV of multilateral debt, has not confirmed its participation.
} 
35. IDA. Debt relief from IDA amounts to $\$ 173.6$ million in PV terms at the Decision Point. Of this amount, IDA has provided $\$ 75.8$ million in end-1999 PV terms as interim relief in the form of a reduction of debt service. IDA suspended the delivery of interim relief in May 2008, after the 50 percent ceiling was reached, equivalent to annual average debt-service savings of $\$ 11.8$ million from 2001-08. ${ }^{20}$ In 2011, IDA cleared SDR 49 million in arrears. ${ }^{21}$ At the completion point, IDA is assumed to provide the remaining amount of relief through a 68.5 percent reduction of Guinea's debt service to IDA through December 2020, equivalent to annual average debt-service savings of $\$ 25.9$ million from October 2012-December 2020 (Table A9).

36. The IMF. Enhanced HIPC assistance from the IMF amounts to SDR 27.8 million (\$36 million) in PV terms at the decision point. Of this amount, an estimated SDR 11.3 million in PV terms (\$14.6 million) had been disbursed between December 2000 and July 2012 in the form of interim assistance. ${ }^{22}$ At the completion point, the IMF will provide the remaining HIPC assistance through a stock-of-debt operation amounting to SDR 16.5 million (\$21.4 million), together with accrued interest currently estimated at SDR 7.5 million. As a result, Guinea's principal debt service payments to the IMF will restart in 2018 (Table A10).

37. The African Development Bank Group. HIPC debt relief from the AfDB Group amounts to US\$94.4 million in PV terms, of which US\$37.6 million in end-1999 PV terms (US\$43.1 million in nominal terms) has already been provided as interim relief. ${ }^{23}$ At the Completion Point, it is assumed that the AfDB Group will provide the remaining amount of relief through a 100 percent reduction of debt service on debt outstanding as of end-December 1999, applied from October 2012 through September 2028 (Table A11).

38. The EU and the EIB. HIPC debt relief from the EU and the EIB amounts to $\$ 36.3$ million of which $\$ 4.3$ million is from the EIB and $\$ 32$ million from the EU. The EU has already provided \$12.0 million in end-1999 PV terms as interim relief. The EU has also cleared arrears on selected loans through a budget support operation in 2011 after cooperation was

\footnotetext{
${ }^{20}$ In January 2008, IDA Management approved the increase of interim relief to Guinea from 33 to 50 percent of IDA' NPV of relief committed under the HIPC Initiative (see "Revised Schedule of IDA'S HIPC Debt Relief to Guinea", IDA/SecM2007-0712, December 26, 2007). In exceptional cases, the Executive Directors have authorized Management to increase the limit on interim relief up to a maximum of 50 percent of the NPV of total debt relief, subject to satisfactory progress in policy performance and the likely benefits of extending interim debt relief. See "Enhanced HIPC Initiative: Proposals Concerning Sunset Clause and Provision of Interim Relief, "IDNR2004-0234, September 15, 2004. So far, Guinea, Guinea-Bissau and Haiti have benefited from the increase in the interim debt relief ceiling.

${ }^{21}$ IDA provided a development policy grant in April 2011 to clear arrears, which means it will not count towards its HIPC contribution (Guinea - Reengagement and Reform Support Grant, IDA/R2011-0096/2).

${ }^{22}$ See footnote 2 .

${ }^{23}$ In August 2008, the Board of Directors of the AfDB and the AfDF approved the increase of interim relief to Guinea from the limit of 40 percent to 50 percent, which implied the delivery of additional US\$10.8 million in debt service reduction from April to December 2008. The additional debt relief was 80 percent financed through a contribution from the HIPC Trust Fund and 20 percent from the AfDB Group's own resources.
} 
resumed after a suspension, and it has frozen arrears on other loans, which will be cleared at the completion point. $^{24}$ The EIB has delivered \$1.5 million in end-1999 PV terms by paying installments on two EU loans in 2002. At the completion point, it is assumed that the EU and the EIB will provide the rest of debt relief by cancelling 100 percent of debt service on selected loans.

39. Assistance from other multilaterals. HIPC debt relief amounts to $\$ 10.4$ million from BADEA, \$18.7 million from the IsDB, and \$4.1 million from OFID in end-1999 PV terms. During 2004-11, BADEA and the IsDB rescheduled accrued arrears and maturities twice, and OFID refinanced accrued arrears through a concessional loan. The PV of HIPC relief in end-1999 terms delivered through these agreements is estimated to amount to $\$ 2.0$ million from BADEA, \$3.9 million from the IsDB, and \$3.0 million from OFID. ${ }^{25}$ HIPC debt relief from International Fund for Agricultural Development (IFAD) amounts to $\$ 8$ million. It is assumed that, at the completion point, IFAD will provide the full amount of debt relief by cancelling 100 percent of debt service falling due through 2017.

\section{Bilateral creditors}

40. Paris Club creditors ${ }^{26}$ have agreed in principle to provide their share of enhanced HIPC assistance (\$188.1 million in end-1999 PV terms) in accordance with the revised HIPC assistance (Tables A2 and A4). Interim assistance has been provided through three flow treatments on Cologne terms, agreed on May 15, 2001; January 23, 2008; and April 11, 2012. Paris Club creditors declared their readiness in principle to provide their full share of assistance at the completion point through a stock-of-debt reduction. A number of Paris Club creditors have also indicated their willingness to provide additional debt relief, which is estimated at about \$482 million in end-2011 PV terms.

\section{Non-Paris Club bilateral creditors are assumed to provide relief on HIPC-eligible} debt on terms comparable to those of the Paris Club. The PV of such relief in end-1999 terms is estimated at $\$ 65.3$ million. The major non-Paris Club creditor is Saudi Arabia, comprising 3.4 percent of HIPC-eligible debt, followed by Kuwait ( 2.8 percent), and China (1.5 percent). In 2009, the Guinean authorities reached agreements with Saudi Arabia and the Kuwait Fund, respectively, to reschedule outstanding claims as of September 2009 which represent full delivery of their respective share of HIPC relief. China has cancelled 100 percent

\footnotetext{
${ }^{24}$ The EU will use European Development Fund (EDF) resources for this arrears clearance, and it has confirmed that it will not count it towards its HIPC debt relief allocation. This means that the remaining delivery of HIPC relief will fully benefit the remaining outstanding loans to the EU.

${ }^{25}$ In 2004 and 2008, BADEA rescheduled accrued arrears falling due in 2005 and 2006 and in 2008, respectively. In 2005 the IsDB rescheduled accrued arrears and payments falling due through December 2006, while it provided a three-year moratorium on payments on selected loans during 2008-10. In 2002, OFID disbursed a concessional loan to refinance $\$ 9.0$ million of existing loans.

${ }^{26}$ Austria, Belgium, Brazil, Canada, France, Germany, Italy, Japan, Norway, Russia, Spain, the United Kingdom, and the United States of America.
} 
of its outstanding claims due before December 31, 2005, representing more than China's expected debt relief as estimated at the Decision Point. Egypt cancelled all its outstanding claims as of 2008. Romania agreed in 2005 to provide debt relief that exceeds its proportionate share of assistance. ${ }^{27}$

42. Negotiations with commercial creditors are ongoing. The Guinean authorities have sent letters to their commercial creditors to request a rescheduling of the existing debt on Paris Club terms. Although agreements have not yet been reached with the commercial creditors, the authorities continue making "good faith" efforts to negotiate comparable treatment of this debt.

\section{Considerations for Exceptional Topping-Up Assistance}

43. The debt relief analysis (DRA) has been updated jointly by the authorities and the IMF and IDA staffs on the basis of loan-by-loan debt data, exchange rates and discount rates as of end-2011 (Table A3). At end-2011, the nominal stock of Guinea's external debt amounted to $\$ 3,193.6$ million. Multilateral creditors accounted for $\$ 1,965.9$ million or 61.6 percent of the total debt, of which IDA, the IMF and the AfDB group accounted for 36.5, 1.3 and 12.3 percent, respectively. Paris club creditors accounted for 25.5 percent of total outstanding nominal debt at end-2011, of which the main creditor remained France. Non-Paris club bilateral creditors accounted for 10.3 percent of total debt, of which main creditors were Kuwait and Saudi Arabia. Commercial creditors accounted for the remaining 2.7 percent of total debt.

44. Guinea does not qualify for topping-up. The PV of debt-to-exports ratio at end-2011 - after full delivery of the HIPC assistance committed at the Decision Point — is now estimated at 132.7 percent, and would decline further to 98.2 percent after full delivery of additional bilateral debt relief beyond the HIPC Initiative (Table A7). This is below the HIPC threshold of 150 percent, although the debt-to-exports ratio after full delivery of HIPC assistance exceeds the end-2011 projection at the Decision Point of 93.8 percent by 38.9 percentage points (Table 3 ). The increase of the ratio is mainly due to the changes in parameters (accounting for 32.4 percentage points), especially lower discount rates compared to end-1999. ${ }^{28}$ Lower-than-expected exports account for 24.0 percentage points. This increase was partially offset by lower-than-expected new borrowing amounting to 29.2 percentage points, while the lower-than-expected concessionality added 14.7 percentage points.

\footnotetext{
${ }^{27}$ In 2007, Libya signed an agreement with Guinea on debt rescheduling, however the agreement is deemed ineffective as Guinea has not made debt service payments in accordance with the agreement, Morocco has agreed to provide debt relief through cancelling their end-1999 claims, however, the Guinean authorities are still trying to obtain a written agreement. North Korea and Iraq agreed in principle to negotiate, however no progress has been made so far.

${ }^{28}$ Table A1 contains the currency-specific discount rates and exchange rates as of end-1999 and end-2011.
} 
Table 2. Factors Affecting PV of Debt-to-Exports Ratio at End-December, $2011^{1}$

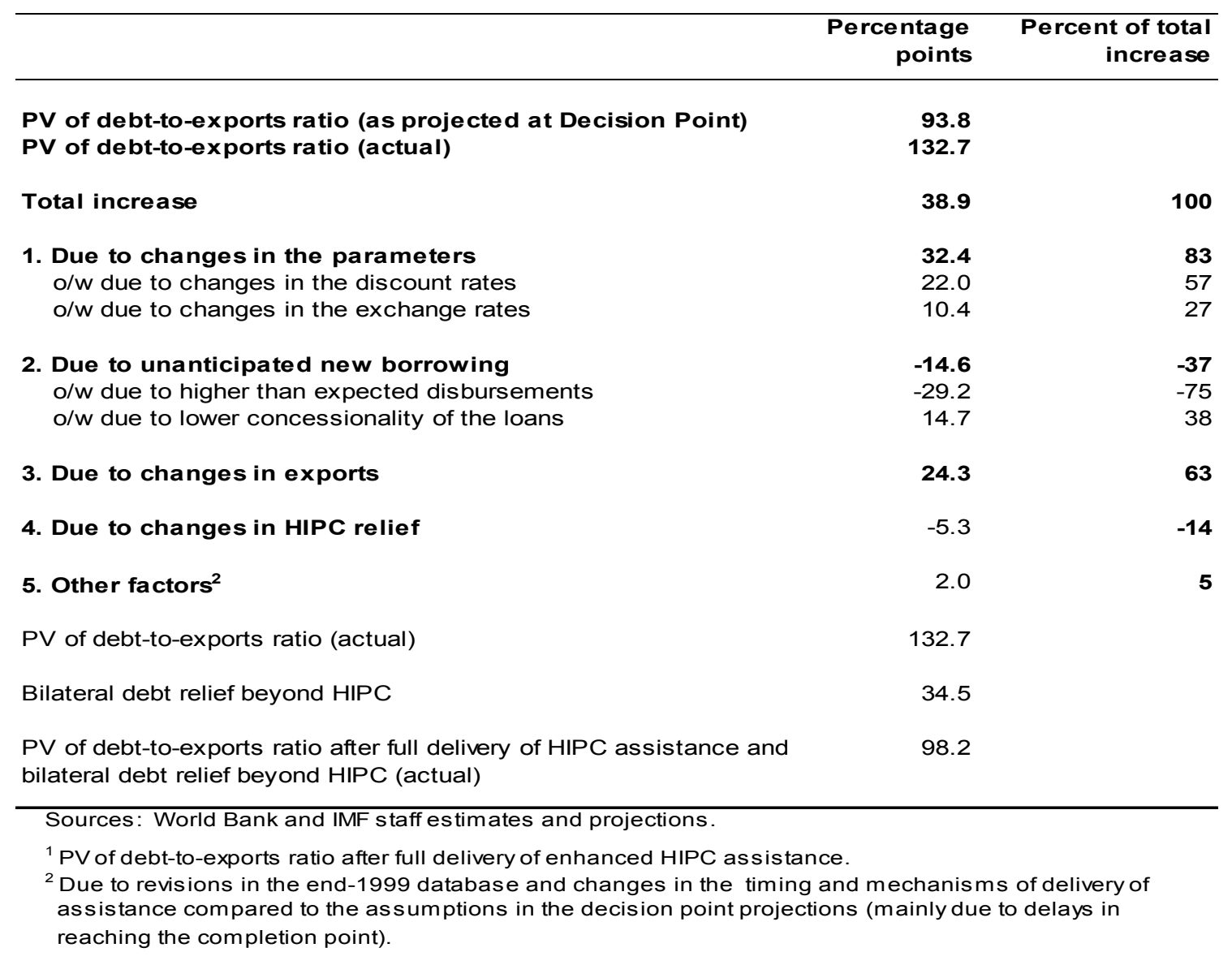

\section{Creditor Participation in the Multilateral Debt Relief Initiative}

45. Contingent upon agreement by the IMF and IDA Executive Directors that Guinea has reached the completion point under the HIPC Initiative, Guinea would qualify for additional debt relief from the Multilateral Debt Relief Initiative (MDRI) from IDA and the AfDF ${ }^{29}$ No MDRI-eligible debt remains due to the IMF at the completion point. MDRI debt relief (net of HIPC assistance) would save Guinea US\$964 million in debt service over a period of 40 years on debt owed to these two institutions.

46. Debt relief from IDA. IDA would provide MDRI debt relief through a debt stock cancellation of debt disbursed before December 31, 2003, and still outstanding on September 30,2012 after the application of full HIPC assistance. ${ }^{30}$ This would reduce what Guinea owes to IDA by $\$ 761.2$ million (Table A9). MDRI debt cancellation from IDA would save Guinea average annual debt service (net of HIPC assistance) of \$27 million between 2012 and 2041. Total debt service savings from MDRI would amount to $\$ 817$ million (SDR 505.5 million).

\footnotetext{
${ }^{29}$ For IDA, eligible debt covers debt disbursed and outstanding as of December 31, 2003. For the AfDF, eligible debt covers debt disbursed and outstanding as of December 31, 2004.
}

${ }^{30}$ See "IDA's implementation of the Multilateral Debt Relief Initiative", IDA/R2006-0042/2 (March 14, 2006). 
47. Debt relief from the AfDF. The AfDF will provide MDRI debt relief by cancelling loans disbursed before 2005 and still outstanding at the completion point. This will yield annual debt service savings (net of HIPC assistance) averaging \$3.3 million for 2012-52. Total MDRI debt service savings would amount to $\$ 147$ million in nominal terms, to be delivered in full at the time of the completion point.

48. Debt relief from the IMF. There will be no MDRI relief from the IMF, as the last loan outstanding at end-2004, was fully repaid by July 2012. The presently outstanding ECF loans were disbursed after end-2004, and will therefore not be eligible for MDRI relief (Table A10).

\section{E. Debt Sustainability Outlook After HIPC and MDRI Assistance, 2011-31}

49. The debt sustainability outlook after HIPC and MDRI assistance is based on medium- and long-term macroeconomic assumptions that rely heavily on a large mining project expected to start production from 2015 and on a continuation of strong macroeconomic policies started recently. The projections are consistent with the medium-term macroeconomic framework under the ECF arrangement; the key assumptions are summarized in Box 2.

\section{After full delivery at the completion point of HIPC Initiative assistance, and} additional bilateral assistance beyond HIPC and MDRI, Guinea's external public debt would be considerably reduced, and external debt indicators would improve (Table A7 and Figure A2). The PV of debt-to-exports ratio would fall from 186 percent at end-2011 to 48.9 percent at end-2012 thanks to full delivery of Enhanced HIPC, MDRI and bilateral beyond-HIPC assistance (Table A7, scenario VI); thereafter, it is projected to fall further to 17.7 percent at end-2031, mainly attributable to an increase in exports following the start of production of a mining project in 2015. The PV of debt-to-GDP ratio would decline from 50.3 percent at end-2011 to an average of 11.8 percent in 2012-21 and 11.1 percent in 2022-31. The PV of debt-to-revenue ratio would decline from 299.4 percent at end-2011 to an average of 60.1 percent in 2012-21 and decrease to an average of 52.2 percent in 2022-31.

51. Guinea's debt service ratios are projected to improve as well (Table A5 and Figure A2). The debt service-to-exports ratio - after HIPC Initiative assistance and additional assistance beyond HIPC and MDRI-would decrease from 8.4 percent in 2012 to 1.6 percent in 2013-14 (Table A7, scenario VI). Thereafter it would fall until 2021 to 0.7 percent mainly thanks to the mining projects. From 2021 onwards, it would gradually rise to around 1.7 percent in 2031 mainly due to new borrowing. The debt service to revenue ratio is projected to fall from 11.6 percent in 2012 to an average of about 3.0 percent in 2012-31. 


\section{Box 2. Guinea: Macroeconomic Assumptions for 2011-32}

Medium- and long-term macroeconomic assumptions rely heavily on a large mining project expected to start production in 2015 and on a continuation of strong macroeconomic policies.

Real GDP growth: Output growth averaged 3 percent during the first half of the 2000s, plunged in 2009-10 as a result of the political crisis, but rebounded to about 4 percent in 2011 as the political and economic situation started to stabilize. Growth is projected to increase to 5 percent on average during 2012 14 , reflecting the start-up of construction-phase activities in the mining sector and strong growth in agriculture following government support. It would jump to 18 percent on average during 2015-18, as production from a major mining project begins and ramps up. Once mining production reaches full capacity, growth tails off and is projected at an average of 3 percent per year after 2020. Non-mining sector growth is projected to stabilize around 5 percent per year in the long run. The reform programs and actions currently undertaken would unlock growth potentials, including support to the agriculture sector; improvement of electricity supply; improvement of the business environment; and integration of the mining activities to the local economy.

Inflation: Inflation has gradually declined from 21 percent in December 2010 to 15 percent in June 2012. In the long run, as measured by the GDP deflator in U.S. dollar terms, inflation is projected to be around 3 percent, close to CPI inflation projections in Guinea and in neighboring countries.

Fiscal policy: Following a large deterioration in the fiscal base balance in 2009-10, reaching 13 percent of GDP in 2010, a sharp policy-induced correction reduced it to 1.6 percent in 2011. The deficit is projected to increase to 3.6 percent of GDP in 2012 due to large investment projects financed with exceptional mining revenue. The deficit would gradually decline and turn into a surplus of about 1 percent of GDP from 2016 as government revenue is expected to be boosted by a large mining project from the middle of the decade. Investment expenditure is projected to expand from 6 percent of GDP in 2000-11, to 12 percent in 2012, and 18 percent in the long run. Current expenditure would average 13 percent of GDP excluding the large mining production during the projection period.

External current account balance (excluding official transfers): The current account deficit is expected to expand sharply to 40 percent of GDP on average during 2012-14, as imports for the mega mining project ramp up during its construction phase. Subsequently, the current account is projected to gradually move to equilibrium as mining sector investment (imports) declines and mining exports come on stream. The government has also provided strong support to the agricultural sector, which has already led to lower food imports. The international reserve position was boosted (from less than one month of imports at end-2010 to above 4 months in June 2012) by exceptional mining revenue; reserves will gradually decline in the medium term until the large iron ore project starts production.

External financing: After the suspension of virtually all official financing in 2009-10, loan and grant disbursements resumed in 2011 and are projected to reach 5 percent of GDP in 2012, of which half takes the form of grants. Although a scaling up is not foreseen, official financing (grants and loans) is expected to continue at a relatively high level in the medium term, hovering around 5 percent of GDP per year until 2015, but would gradually decline thereafter as domestic revenue from the mining sector would ramp up and finance public investment projects. Over time, the share of concessional loans is expected to decline, from 60 percent during 2011-17, to 40 percent during 2018-25 and 30 percent during 2026-32.

Foreign direct investment: Net FDI is expected to surge temporarily to above 30 percent of GDP per year on average during 2012-15, owing to the rapid buildup in mining related activities. Subsequently net FDI falls and over the long run shifts between small net inflows and outflows. At the same time, net outflows on the income account increase, as the repatriation and distribution of profits from the mining sector rises. 


\section{F. Sensitivity Analysis and Long-Term Debt Sustainability}

52. This section analyzes the impact on debt dynamics of three alternative scenarios: permanently lower GDP growth; permanently lower export growth; and lower average concessionality for new external borrowing (Table A8 and Figure A3). The assumptions for the alternative scenarios are chosen to illustrate independently the effects of domestic and external shocks. In the case of Guinea, given the nexus between projected growth, mining activity and exports, mining sector related foreign direct investment, the shocks could also occur in combination, resulting in an aggravated negative impact on debt burden indicators. The baseline and all three scenarios assume full delivery of HIPC debt relief, MDRI and bilateral beyond HIPC assistance.

\section{Alternative Scenario 1: Permanently Lower GDP Growth}

53. This scenario assumes that real GDP growth is reduced by 2.5 percentage points compared to projections in the baseline. This reduction in growth rates could be linked to political instability (as was the case in 2008) or a halt in important structural reforms. The lower growth would consequently reduce government revenue while exports remain unaffected. Under this scenario, the PV of debt-to-exports ratio would be unchanged at 17.7 percent in 2031 as under the baseline scenario. The PV of debt -to-revenue ratio would reach 43.2 percent in 2031, compared to 35 percent under the baseline. The PV of debt-to-GDP ratio would be 12.9 percent as compared to the baseline of 8.4 percent.

\section{Alternative Scenario 2: Permanently Lower Exports Growth}

54. In this scenario, exports are assumed to grow at lower pace than the baseline due to lower-than-expected production from the mining project. GDP and revenue are also adjusted downward compared to the baseline. Based on these assumptions, the PV of debt-to-export ratio would deteriorate to 35.2 percent in 2031 compared to the baseline of 17.7 percent. The debt service-to-export ratio would also be higher than under the baseline at 3.3 percent compared to 1.7 percent. The PV of debt-to-revenue would be 35.9 percent as compared to 35.0 percent in the baseline in 2031.

\section{Alternative Scenario 3: Lower Average Concessionality of New Borrowing}

55. This scenario assumes a lower concessionality of new external financing, specifically a shift from concessional multilateral to nonconcessional bilateral and commercial borrowing causing the average grant element to drop by about 18 percentage points. In this scenario, average concessionality of new borrowing from 2012 to 2031 would fall from 33.0 percent under the baseline to 15.2 percent. ${ }^{31}$ The average PV of debt-to-exports would increase from 32.3 percent in the baseline to 34.3 percent in 2012-2021. The average debt service-to-exports ratio during this period would be 2.3 percent as compared to 1.8 percent in the baseline.

\footnotetext{
${ }^{31}$ Under the baseline scenario, the share of multilateral creditors in new borrowing would decrease from 60 percent in 2013-17, to 40 percent in 2018-25, and 30 percent in 2026-32. Under the alternative scenario, the figures are, respectively, 20, 10 and 5 percent; remaining borrowing would be nonconcessional.
} 
56. Guinea's future external debt position will be affected by the modalities of the government's participation in large-scale infrastructure and mining projects. In the near-term this issue has been brought to the forefront by the prospective SIMFER mining and infrastructure project. The total cost of the two projects, tentatively estimated at about \$17-18 billion (one-third mining and two-thirds for infrastructure), is to be shared in proportion to each shareholder's equity. The government has options to hold up to 35 percent (15 percent at no cost) in the mining project and up to 51 percent in the infrastructure project. As of now the government has made no decision regarding how much of its possible stake to take up or on the financing of its contribution. It has, however, stated clearly that its participation will not involve direct borrowing or guarantees by the government. Instead it will rely on private-public partnerships through special purpose financing vehicles for which financing costs would be fully covered by project revenues, and involve no contingent liabilities to the government. The participation of the IFC in the SIMFER and possible participation of the World Bank in the infrastructure project should help ensure that the projects are designed to generate large economic and social returns. Given the magnitude of these projects and possible future ones, it will be important that the government strengthen its capacity to develop sound and transparent public private partnerships, ensure that any financing agreement does not include contingent liabilities, and that projections of revenues are well-based and sufficient to cover financing costs of the PPP. This would help to avoid possible implicit contingent liabilities in situations where the collapse of a project could have widespread damaging economic and social impacts. The assumption of any such liability, could lead to sharp deterioration in debt burden indicators, particularly on debt service ratios. ${ }^{32}$

\section{Although the sensitivity analysis illustrates that Guinea's debt sustainability} outlook after debt relief has become more robust to single shocks, it may be vulnerable to the impact of combined shocks. The LIC-DSA (Appendix II) also considers possible vulnerabilities from combined shocks related to the mining sector and underscores the importance of policies to reduce the potential vulnerability of Guinea's external and fiscal sustainability, including the need to avoid any explicit or implicit contingent liabilities stemming from PPP agreements.

\section{Conclusions}

58. In the view of the staffs of IDA and the IMF, Guinea made satisfactory progress with meeting the requirements established in December 2000 for reaching the completion point under the enhanced HIPC Initiative. Nine of the ten triggers have been met.

Notwithstanding capacity limitations, good progress was made in achieving the objectives of the remaining trigger, for which the authorities have requested a waiver. During the decade following the Decision Point, performance regarding the implementation of the PRSP was unsteady and PRGF-supported programs were interrupted. However, since the first

\footnotetext{
${ }^{32}$ See also the discussion of such risks in Supplement of IMF Country Report No. 12/63, March 2012, on LIC-DSA which can be found at: http://www.imf.org/external/pubs/ft/scr/2012/cr1263.pdf.
} 
democratically elected government took office in early 2011, policy implementation has considerably improved. The PRSP has been satisfactorily implemented in 2011.

Macroeconomic stability has been restored and maintained, as evidenced by the satisfactory track record under the SMP in 2011 and the ECF-supported program during the first half of 2012; quantitative targets and criteria have been met and there was good progress with structural reform. Satisfactory progress was made in the health and education sectors and on other poverty reducing measures. With regard to the Governance criteria, Guinea met the trigger on the publication of a one-year progress report of the Anti-corruption Committee. Audit reports on public procurement contracts were prepared and published, although, for practical reasons and to improve the speed of completion of the reports, the audits were limited to a sample, starting in 2008. Given the resulting improvements in completing and publishing reports following this change, the staffs of the IDA and the IMF support the authorities request for a waiver regarding this trigger.

\section{The debt reconciliation exercise resulted in an upward revision of the}

HIPC-eligible external debt in present value (PV) terms at end-1999. The common reduction factor increased from 31.6 percent to 36.2 percent; and the amount of HIPC debt relief required to reduce the PV of debt to 150 percent of exports on the basis of end-December 1999 data has been revised upward from $\$ 545$ million estimated at the Decision Point to $\$ 639$ million. Assurances have been received regarding participation in the enhanced HIPC Initiative from creditors representing 97.5 percent of the PV of HIPC debt relief estimated at the Decision Point.

60. The IDA and IMF staffs are of the view that Guinea does not qualify for toppingup under the HIPC Initiative. After full delivery of HIPC assistance committed at the Decision Point and additional bilateral debt relief beyond the HIPC Initiative, the PV of debt-to-exports ratio at end-2011 would decline to 98 percent, well below the HIPC threshold of 150 percent.

61. Full delivery of HIPC debt relief, additional bilateral assistance beyond HIPC, and MDRI, would considerably reduce Guinea's external public debt. Its risk of debt distress according to the Low-Income Country Debt Sustainability Analysis (LIC-DSA) will become moderate, after having been assessed as "in debt distress" in 2007 and at "high risk of debt distress" in February 2012 (Appendix II). However, the recurrence of external shocks and/or policy slippages as in the past and the resumption of nonconcessional borrowing could lead to the reemergence of unsustainable debt. Improvement in the quality of debt management, strengthened capacity to evaluate potential government liabilities of PPP agreements, sound macroeconomic policies, and improvement $\mathrm{s}$ in the business environment will be crucial to achieving and maintaining a sustainable debt level.

62. In light of the above, the staffs of IDA and IMF recommend that the Executive Directors determine that Guinea has reached the completion point under the Enhanced HIPC Initiative. 


\section{ISSUES FOR DISCUSSIONS}

\section{The Executive Directors may wish to consider the following questions:}

- Completion point. Do Directors agree that Guinea has reached the completion point under the Enhanced HIPC Initiative?

- Data Revision. Do Directors agree with staffs' recommendation that the revised export data and the updated stock of debt in end-1999 PV terms warrant a revision in the proposed amount of HIPC assistance, from \$545.4 million to \$639.2 million in end-1999 PV terms?

- HIPC assistance from the IMF. Do IMF Directors agree that Guinea qualifies for an amount of debt relief from the IMF equal to SDR 16.5 million, together with accrued interest, currently estimated at SDR 7.5 million, which would be financed from Guinea's HIPC Umbrella sub-account?

- Topping-up. Do the Directors agree that Guinea has not met the requirements for exceptional topping-up at the completion point?

- Creditor Participation. Do Directors agree that Guinea's creditors have given sufficient assurances to irrevocably commit HIPC Initiative assistance to Guinea? 
Figure A1. Guinea: Composition of External Debt by Creditor Groups, End-1999 and End-2011

(In percent of total)

(Nominal stock at end-1999: US\$3,419 million)

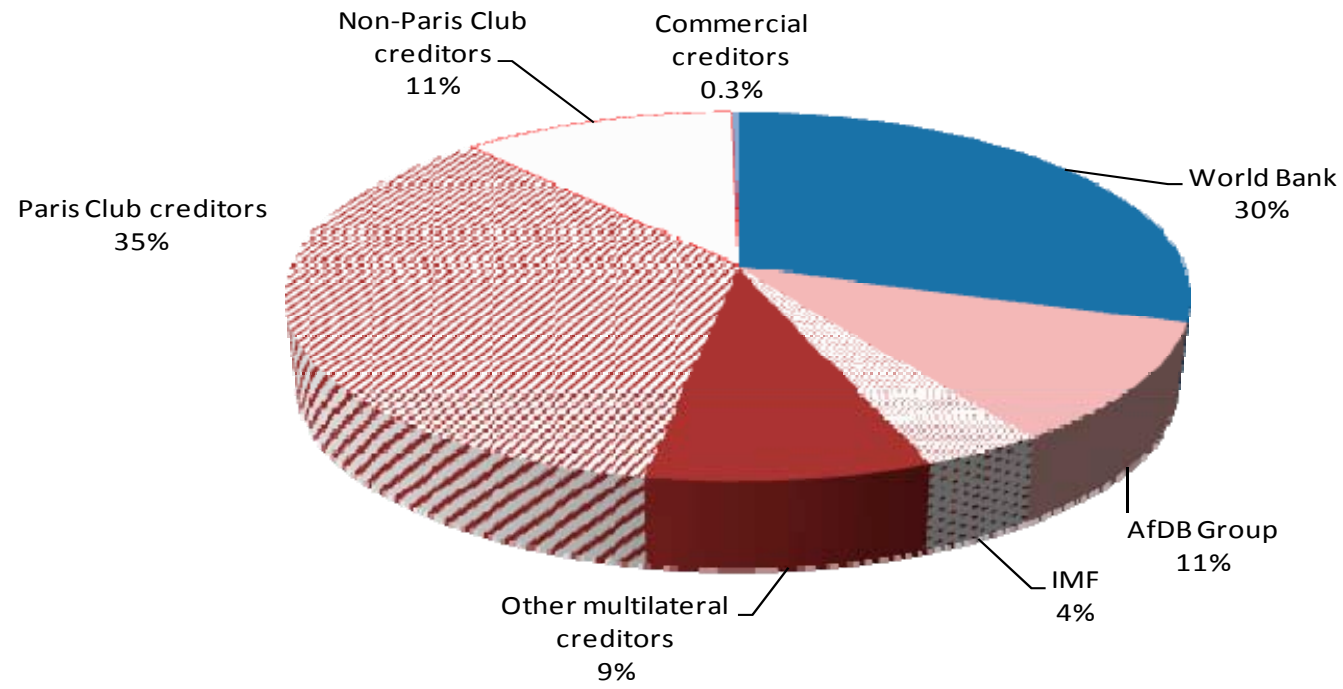

(Nominal stock at end-2011: US\$3,194 million)

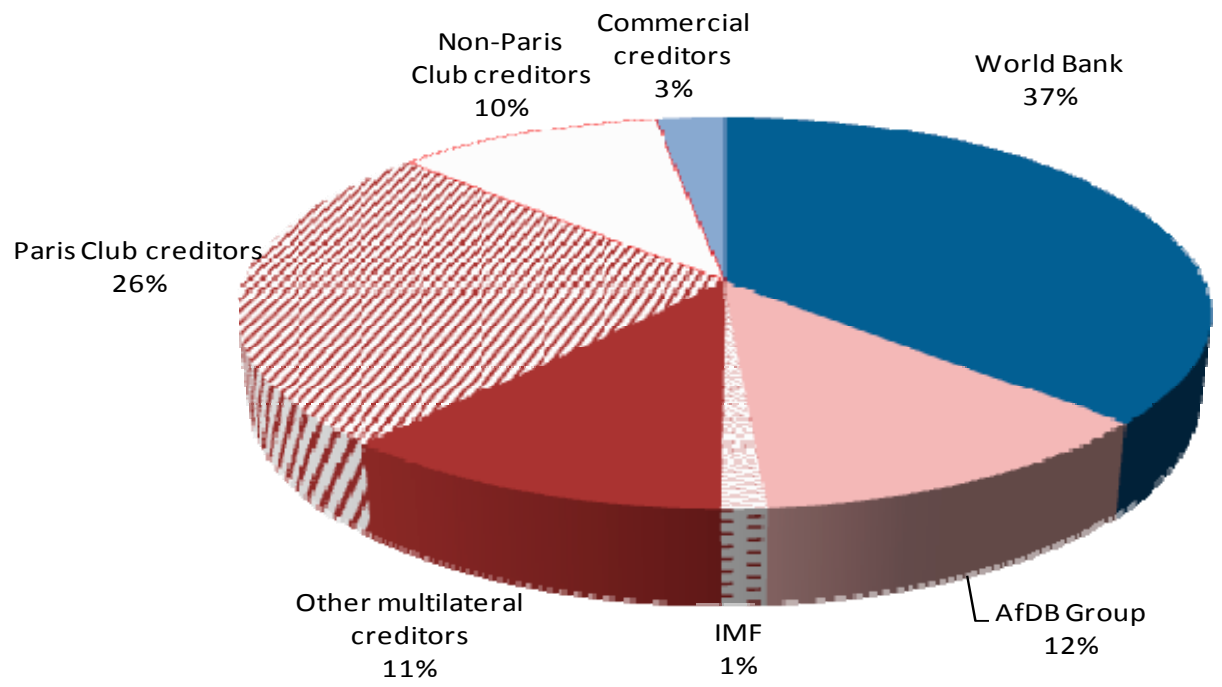

Sources: Guinean authorities, and World Bank and IMF staff . 


\section{Figure A2. Guinea: External Debt and Debt Service Indicators for Medium- and Long-Term Public Sector Debt, 2011-31}

PV of External Debt to Exports (\%)
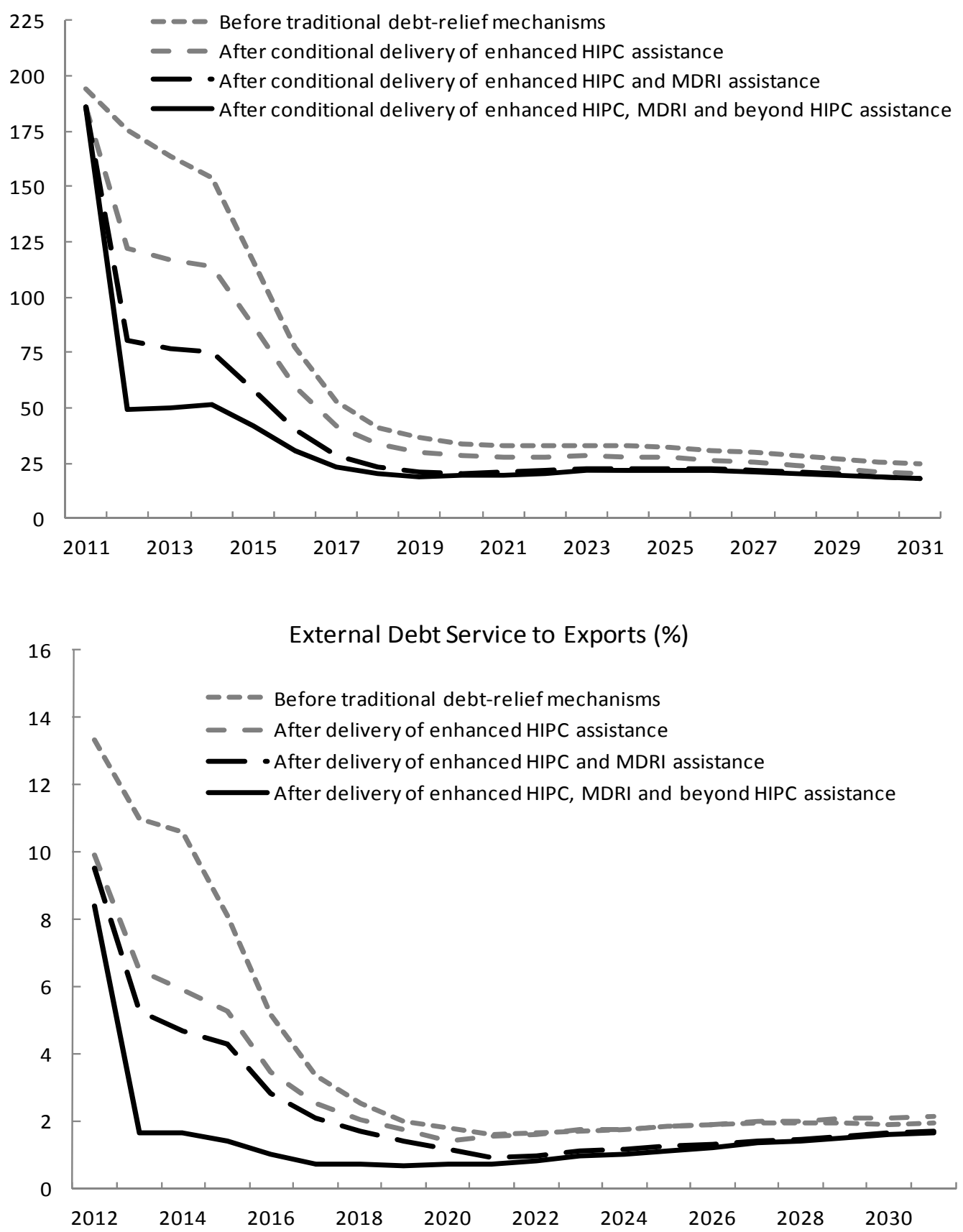

Sources: Guinean authorities, and World Bank and IMF staff estimates and projections.

Conditional delivery means that the PV of debt at end-2011 only assumes delivery of interim HIPC relief in 2012 until the completion point without any HIPC debt relief after the completion point, whereas the PV of debt from 2012 onwards assumes full delivery of HIPC relief. 
Figure A3. Guinea: Sensitivity of Long-Term Debt Sustainability after Shocks, 2011-31 (After full delivery of HIPC, MDRI and beyond HIPC relief)
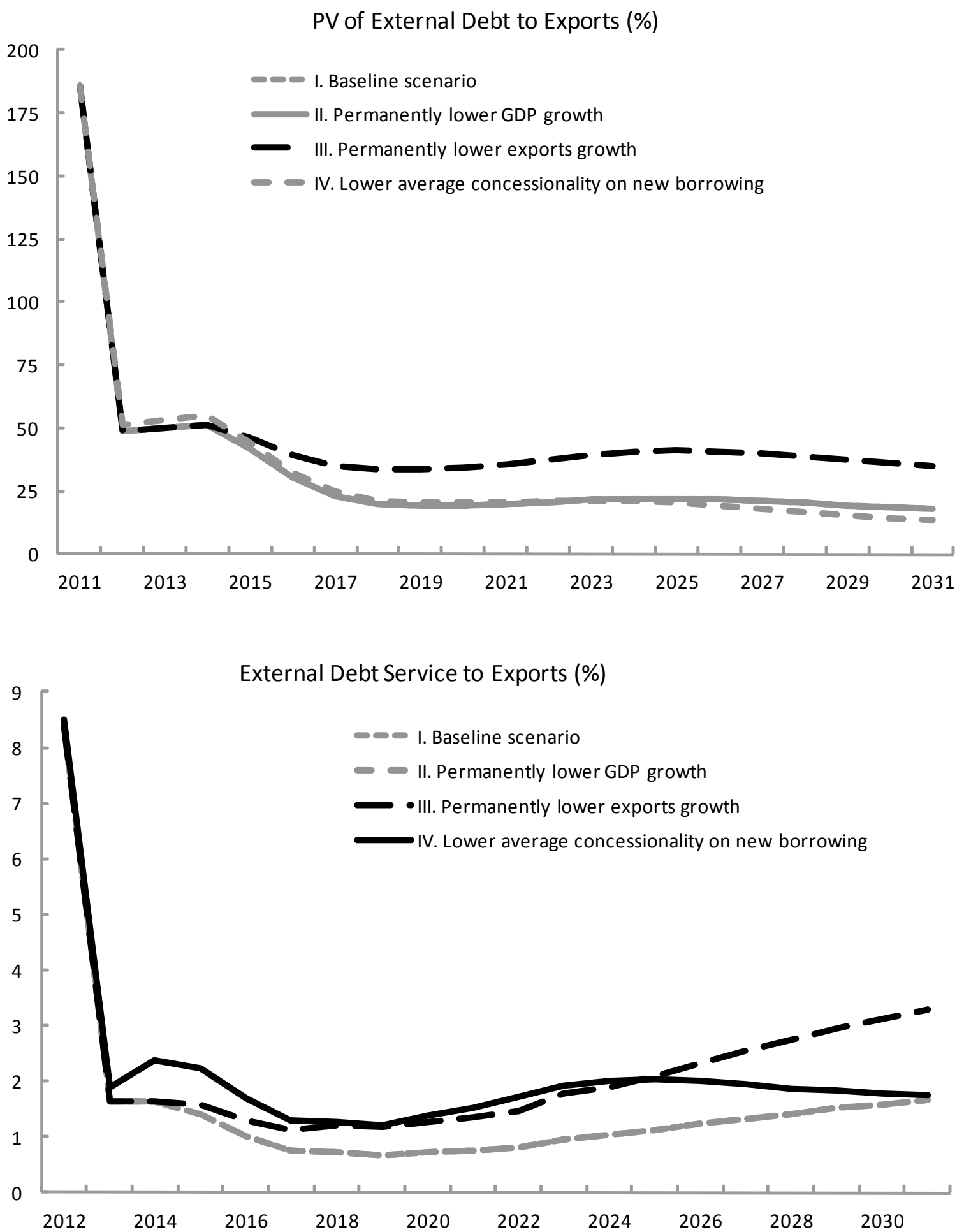

Sources: Guinean authorities, and World Bank and IMF staff estimates and projections. 
Table A1. Guinea: Comparison of Discount Rate and Exchange Rate Assumptions

\begin{tabular}{|c|c|c|c|c|}
\hline & \multicolumn{2}{|c|}{$\begin{array}{c}\text { Discount Rates }{ }^{1} \\
\text { (in percent per annum) }\end{array}$} & \multicolumn{2}{|c|}{$\begin{array}{c}\text { Exchange Rates }{ }^{2} \\
\text { (currency per U.S. dollar) }\end{array}$} \\
\hline & $\begin{array}{r}\text { At decision point } \\
\text { End-Dec. } 1999\end{array}$ & $\begin{array}{r}\text { At completion point } \\
\text { End-Dec. } 2011\end{array}$ & $\begin{array}{r}\text { At decision point } \\
\text { End-Dec. } 1999\end{array}$ & $\begin{array}{r}\text { At completion point } \\
\text { End-Dec. } 2011\end{array}$ \\
\hline \multicolumn{5}{|l|}{ Currency } \\
\hline Unit of Account (ISDB, AfDF/AfDB) ${ }^{3}$ & 5.59 & 3.09 & 0.73 & 0.65 \\
\hline Canadian Dollar & 6.67 & 3.23 & 1.44 & 1.02 \\
\hline CFA Franc ${ }^{4}$ & 5.47 & 3.52 & 652.95 & 506.96 \\
\hline Swiss Franc & 4.27 & 2.05 & 1.60 & 0.94 \\
\hline Chinese Yuan ${ }^{3}$ & 5.59 & 3.09 & 8.28 & 6.30 \\
\hline Danish Kroner & 5.32 & 3.21 & 7.40 & 5.75 \\
\hline Euro & 5.47 & 3.52 & 1.00 & 0.77 \\
\hline Great Britain Sterling & 6.70 & 3.37 & 0.62 & 0.65 \\
\hline Japanese Yen & 1.98 & 1.63 & 102.20 & 77.72 \\
\hline Kuwaiti Dinar ${ }^{3}$ & 5.59 & 3.09 & 0.30 & 0.28 \\
\hline Libyan Dinar ${ }^{3}$ & 5.59 & 3.09 & 0.46 & 1.26 \\
\hline Norwegian Kroner & 6.64 & 3.33 & 8.04 & 5.99 \\
\hline Saudi Arabia Riyal ${ }^{3}$ & 5.59 & 3.09 & 3.75 & 3.75 \\
\hline Special Drawing Rights & 5.59 & 3.09 & 0.73 & 0.65 \\
\hline Swedish Kroner & 5.80 & 3.27 & 8.53 & 6.89 \\
\hline Russian Rouble ${ }^{5}$ & 7.04 & 2.96 & 0.60 & 0.60 \\
\hline United States Dollar & 7.04 & 2.96 & 1.00 & 1.00 \\
\hline
\end{tabular}

Sources: OECD; IMF, International Financial Statistics.

${ }^{1}$ The discount rates used are the average commercial interest reference rates (CIRRs) for the respective currencies over the six-month period ending in December 2011 for the completion point and in December 1999 for the decision point.

${ }^{2}$ End-of-period exchange rates.

${ }^{3}$ Apply the discount rate for SDR.

${ }^{4}$ Apply the discount rate for EUR.

${ }^{5}$ Former Soviet Union Ruble. Apply the discount rate for USD. 
Table A2. Guinea: Revised Nominal Stocks and Net Present Value of Debt at Decision Point by Creditor Groups 1/ (As of end-1999)

\begin{tabular}{|c|c|c|c|c|c|c|c|c|c|c|c|c|}
\hline & \multicolumn{4}{|c|}{ Nominal Debt Stock at End-1999 } & \multicolumn{4}{|c|}{ PV of Debt Before Rescheduling ${ }^{2}$} & \multicolumn{4}{|c|}{ PV of Debt After Rescheduling ${ }^{2}$} \\
\hline & \multicolumn{2}{|c|}{ At Decision Point } & \multicolumn{2}{|c|}{$\begin{array}{c}\text { Revised At } \\
\text { Completion Point } \\
\end{array}$} & \multicolumn{2}{|c|}{ At Decision Point } & \multicolumn{2}{|c|}{$\begin{array}{c}\text { Revised At } \\
\text { Completion Point } \\
\end{array}$} & \multicolumn{2}{|c|}{ At Decision Point } & \multicolumn{2}{|c|}{$\begin{array}{c}\text { Revised At } \\
\text { Completion Point }\end{array}$} \\
\hline & $\begin{array}{c}\text { US\$ } \\
\text { million }\end{array}$ & $\begin{array}{l}\text { Percent } \\
\text { of total }\end{array}$ & $\begin{array}{c}\text { US\$ } \\
\text { million }\end{array}$ & $\begin{array}{l}\text { Percent } \\
\text { of total }\end{array}$ & $\begin{array}{l}\text { US\$ } \\
\text { million }\end{array}$ & $\begin{array}{l}\text { Percent } \\
\text { of total }\end{array}$ & $\begin{array}{l}\text { US\$ } \\
\text { million }\end{array}$ & $\begin{array}{l}\text { Percent } \\
\text { of total }\end{array}$ & $\begin{array}{l}\text { US\$ } \\
\text { million }\end{array}$ & $\begin{array}{l}\text { Percent } \\
\text { of total }\end{array}$ & $\begin{array}{c}\text { US\$ } \\
\text { million }\end{array}$ & $\begin{array}{l}\text { Percent } \\
\text { of total }\end{array}$ \\
\hline Total & $3,374.8$ & 100 & $3,419.1$ & 100 & $2,414.8$ & 100 & $2,478.2$ & 100 & $1,727.2$ & 100 & $1,765.6$ & 100 \\
\hline Multilateral institutions & $1,810.0$ & 53.6 & $1,805.8$ & 52.8 & $1,039.2$ & 43.0 & $1,058.0$ & 42.7 & $1,039.2$ & 60.2 & $1,058.0$ & 59.9 \\
\hline African Development Bank & 117.2 & 3.5 & 116.4 & 3.4 & 129.0 & 5.3 & 130.7 & 5.3 & 129.0 & 7.5 & 130.7 & 7.4 \\
\hline African Development Fund & 248.8 & 7.4 & 248.6 & 7.3 & 109.6 & 4.5 & 130.0 & 5.2 & 109.6 & 6.3 & 130.0 & 7.4 \\
\hline BADEA & 34.3 & 1.0 & 34.3 & 1.0 & 28.7 & 1.2 & 28.6 & 1.2 & 28.7 & 1.7 & 28.6 & 1.6 \\
\hline ECOWAS Bank for Investment and Development & 4.5 & 0.1 & 4.5 & 0.1 & 4.6 & 0.2 & 4.6 & 0.2 & 4.6 & 0.3 & 4.6 & 0.3 \\
\hline European Investment Bank & 12.6 & 0.4 & 12.6 & 0.4 & 12.1 & 0.5 & 11.8 & 0.5 & 12.1 & 0.7 & 11.8 & 0.7 \\
\hline European Union (administered by EIB) & 128.4 & 3.8 & 128.4 & 3.8 & 88.3 & 3.7 & 88.3 & 3.6 & 88.3 & 5.1 & 88.3 & 5.0 \\
\hline European Union (administered by IDA) ${ }^{3}$ & 2.7 & $\ldots$ & & & 1.5 & $\ldots$ & $\ldots$ & & 1.5 & & & $\ldots$ \\
\hline World Bank (IDA) & $1,012.8$ & 30.0 & $1,012.8$ & 29.6 & 479.5 & 19.9 & 479.5 & 19.3 & 479.5 & 27.8 & 479.5 & 27.2 \\
\hline IFAD & 44.4 & 1.3 & 44.4 & 1.3 & 22.1 & 0.9 & 22.1 & 0.9 & 22.1 & 1.3 & 22.1 & 1.3 \\
\hline IMF & 127.2 & 3.8 & 127.2 & 3.7 & 99.5 & 4.1 & 99.5 & 4.0 & 99.5 & 5.8 & 99.5 & 5.6 \\
\hline Islamic Development Bank & 63.7 & 1.9 & 63.5 & 1.9 & 52.8 & 2.2 & 51.6 & 2.1 & 52.8 & 3.1 & 51.6 & 2.9 \\
\hline OPEC Fund for International Development & 13.4 & 0.4 & 13.1 & 0.4 & 11.6 & 0.5 & 11.3 & 0.5 & 11.6 & 0.7 & 11.3 & 0.6 \\
\hline Official bilateral and commercial & $1,564.8$ & 46.4 & $1,613.3$ & 47.2 & $1,375.6$ & 57 & $1,420.2$ & 57.3 & 688.0 & 40 & 707.6 & 40.1 \\
\hline Paris Club & $1,177.9$ & 34.9 & $1,215.5$ & 35.6 & $1,036.8$ & 43 & $1,072.3$ & 43.3 & 482.1 & 28 & 519.7 & 29.4 \\
\hline Post-cutoff date & 272.8 & 8.1 & 326.6 & 9.6 & 220.1 & 9 & 268.8 & 10.8 & 220.1 & 13 & 268.8 & 15.2 \\
\hline Pre-cutoff date, of which: & 905.1 & 26.8 & 888.9 & 26.0 & 816.7 & 34 & 803.5 & 32.4 & 262.0 & 15 & 250.9 & 14.2 \\
\hline ODA & 152.8 & 4.5 & 140.4 & 4.1 & 108.9 & 5 & 97.4 & 3.9 & 84.4 & 5 & 74.4 & 4.2 \\
\hline Non-ODA & 752.4 & 22.3 & 748.5 & 21.9 & 707.8 & 29 & 706.1 & 28.5 & 177.6 & 10 & 176.5 & 10.0 \\
\hline \multicolumn{13}{|l|}{ Of which: } \\
\hline Austria & 12.6 & 0.4 & 12.9 & 0.4 & 7.6 & 0 & 8.0 & 0.3 & 4.5 & 0 & 4.4 & 0.2 \\
\hline Belgium & 9.1 & 0.3 & 11.9 & 0.3 & 6.6 & 0 & 8.1 & 0.3 & 3.2 & 0 & 4.4 & 0.2 \\
\hline Brazil & 11.3 & 0.3 & 11.3 & 0.3 & 5.8 & 0 & 3.9 & 0.2 & 3.9 & 0 & 3.7 & 0.2 \\
\hline France & 345.4 & 10.2 & 327.0 & 9.6 & 291.7 & 12 & 282.1 & 11.4 & 254.0 & 15 & 244.8 & 13.9 \\
\hline Germany & 3.9 & 0.1 & 3.8 & 0.1 & 4.4 & 0 & 4.3 & 0.2 & 2.4 & 0 & 2.3 & 0.1 \\
\hline Italy & 48.9 & 1.4 & 53.9 & 1.6 & 38.7 & 2 & 43.1 & 1.7 & 23.7 & 1 & 24.9 & 1.4 \\
\hline Japan & 81.8 & 2.4 & 119.2 & 3.5 & 75.0 & 3 & 104.1 & 4.2 & 58.0 & 3 & 91.7 & 5.2 \\
\hline Norway & 12.5 & 0.4 & 18.3 & 0.5 & 11.6 & 0 & 17.0 & 0.7 & 6.7 & 0 & 10.5 & 0.6 \\
\hline Russia & 498.0 & 14.8 & 498.0 & 14.6 & 489.0 & 20 & 491.5 & 19.8 & 57.3 & 3 & 56.8 & 3.2 \\
\hline Spain & 17.4 & 0.5 & 17.7 & 0.5 & 12.8 & 1 & 11.3 & 0.5 & 6.5 & 0 & 7.5 & 0.4 \\
\hline United Kingdom & 8.4 & 0.2 & 7.9 & 0.2 & 5.8 & 0 & 5.4 & 0.2 & 2.9 & 0 & 2.7 & 0.2 \\
\hline United States of America & 128.5 & 3.8 & 131.0 & 3.8 & 87.6 & 4 & 92.1 & 3.7 & 59.0 & 3 & 65.1 & 3.7 \\
\hline EEC-IDA administered loans ${ }^{3}$ & $\ldots$ & $\ldots$ & 2.7 & 0.1 & $\ldots$ & $\ldots$ & 1.5 & 0.1 & $\ldots$ & $\ldots$ & 0.7 & 0.0 \\
\hline Non-Paris Club Official Bilateral & 376.9 & 11.2 & 387.8 & 11.3 & 331.2 & 14 & 340.2 & 13.7 & 198.3 & 11 & 180.3 & 10.2 \\
\hline Post-cutoff date & 158.2 & 4.7 & 152.2 & 4.5 & 125.4 & 5 & 117.2 & 4.7 & 131.2 & 8 & 116.9 & 6.6 \\
\hline Pre-cutoff date & 218.7 & 6.5 & 235.6 & 6.9 & 205.8 & 9 & 223.0 & 9.0 & 67.1 & 4 & 63.4 & 3.6 \\
\hline Of which: ODA & 105.6 & 3.1 & 107.1 & 3.1 & 92.7 & 4 & 94.6 & 3.8 & 29.4 & 2 & 20.9 & 1.2 \\
\hline Non-ODA & 113.2 & 3.4 & 128.4 & 3.8 & 113.2 & 5 & 128.4 & 5.2 & 37.7 & 2 & 42.4 & 2.4 \\
\hline \multicolumn{13}{|l|}{ Of which: } \\
\hline Bulgaria & 10.4 & 0.3 & 10.4 & 0.3 & 10.4 & 0 & 10.4 & 0.4 & 3.5 & 0 & 3.4 & 0.2 \\
\hline China & 97.0 & 2.9 & 108.4 & 3.2 & 83.2 & 3 & 93.1 & 3.8 & 25.7 & 1 & 27.1 & 1.5 \\
\hline Egypt & 8.6 & 0.3 & 8.6 & 0.3 & 8.0 & 0 & 8.0 & 0.3 & 9.5 & 1 & 7.9 & 0.4 \\
\hline Iraq & 5.8 & 0.2 & 5.8 & 0.2 & 5.8 & 0 & 5.8 & 0.2 & 1.9 & 0 & 1.9 & 0.1 \\
\hline Korea, DPR & 1.9 & 0.1 & 1.4 & 0.0 & 1.9 & 0 & 1.2 & 0.0 & 0.5 & 0 & 0.2 & 0.0 \\
\hline Kuwait & 79.1 & 2.3 & 79.1 & 2.3 & 66.4 & 3 & 66.3 & 2.7 & 50.6 & 3 & 48.6 & 2.8 \\
\hline Libya & 35.6 & 1.1 & 35.6 & 1.0 & 35.6 & 1 & 35.6 & 1.4 & 11.9 & 1 & 11.8 & 0.7 \\
\hline Morocco & 24.7 & 0.7 & 24.7 & 0.7 & 24.7 & 1 & 24.7 & 1.0 & 8.2 & 0 & 8.1 & 0.5 \\
\hline Romania & 15.3 & 0.5 & 15.3 & 0.4 & 15.3 & 1 & 15.3 & 0.6 & 15.3 & 1 & 5.0 & 0.3 \\
\hline Saudi Arabia & 83.8 & 2.5 & 83.8 & 2.5 & 65.1 & 3 & 65.1 & 2.6 & 65.5 & 4 & 60.4 & 3.4 \\
\hline Thailand & 1.3 & 0.0 & 1.3 & 0.0 & 1.3 & 0 & 1.3 & 0.1 & 1.3 & 0 & 1.3 & 0.1 \\
\hline Yugoslavia & 13.5 & 0.4 & 13.5 & 0.4 & 13.5 & 1 & 13.5 & 0.5 & 4.5 & 0 & 4.5 & 0.3 \\
\hline Commercial & 10.0 & 0.3 & 10.0 & 0.3 & 7.6 & 0 & 7.6 & 0.3 & 7.6 & 0 & 7.6 & 0.4 \\
\hline
\end{tabular}

${ }^{1}$ Information based on latest data available at completion point.

${ }^{2}$ Stock of debt operation on Naples terms from official bilateral and commercial creditors.

${ }^{3}$ EEC loans administered by IDA were reclassified as official bilateral claims in February 2005. 
Table A3. Guinea: Nominal and Present Value of External Debt outstanding at End-December 2011 1/

(In millions of \$, unless otherwise indicated)

\begin{tabular}{|c|c|c|c|c|c|c|c|}
\hline & \multicolumn{4}{|c|}{ Legal Situation ${ }^{2}$} & \multicolumn{3}{|c|}{ Present Value of Debt ${ }^{3}$} \\
\hline & $\begin{array}{c}\text { Nominal } \\
\text { Debt }\end{array}$ & $\begin{array}{l}\text { Percent } \\
\text { of total }\end{array}$ & PV of debt & $\begin{array}{l}\text { Percent } \\
\text { of total }\end{array}$ & $\begin{array}{c}\text { After } \\
\text { enhanced } \\
\text { HIPC relief }\end{array}$ & $\begin{array}{c}\text { After additional } \\
\text { bilateral relief }\end{array}$ & $\begin{array}{l}\text { After additional } \\
\text { bilateral relief } \\
\text { (In percent of } \\
\text { total debt) }\end{array}$ \\
\hline Total & $3,193.6$ & 100.0 & $2,704.2$ & 100.0 & $1,854.8$ & $1,373.0$ & 100.0 \\
\hline Multilateral institutions & $1,965.9$ & 61.6 & $1,551.4$ & 57.4 & $1,058.8$ & $1,058.8$ & 77.1 \\
\hline African Development Bank Group & 392.9 & 12.3 & 301.6 & 11.2 & 173.6 & 173.6 & 12.6 \\
\hline African Development Bank & 1.1 & 0.0 & 1.2 & 0.0 & 1.2 & 1.2 & 0.1 \\
\hline African Development Fund & 391.8 & 12.3 & 300.4 & 11.1 & 172.4 & 172.4 & 12.6 \\
\hline BADEA & 32.6 & 1.0 & 32.1 & 1.2 & 11.0 & 11.0 & 0.8 \\
\hline ECOWAS Bank for Investment and Development & 34.0 & 1.1 & 33.4 & 1.2 & 31.2 & 31.2 & 2.3 \\
\hline European Investment Bank & 0.0 & 0.0 & 0.0 & 0.0 & 0.0 & 0.0 & 0.0 \\
\hline European Union (administered by EIB $)^{4}$ & 59.4 & 1.9 & 49.6 & 1.8 & 0.0 & 0.0 & 0.0 \\
\hline World Bank (IDA) & $1,165.8$ & 36.5 & 897.2 & 33.2 & 676.1 & 676.1 & 49.2 \\
\hline IFAD & 82.6 & 2.6 & 62.6 & 2.3 & 43.2 & 43.2 & 3.1 \\
\hline IMF & 41.5 & 1.3 & 36.6 & 1.4 & 5.1 & 5.1 & 0.4 \\
\hline Islamic Development Bank & 143.4 & 4.5 & 126.2 & 4.7 & 108.1 & 108.1 & 7.9 \\
\hline OPEC Fund for International Development & 13.6 & 0.4 & 12.0 & 0.4 & 10.7 & 10.7 & 0.8 \\
\hline Official bilateral and commercial & $1,227.7$ & 38.4 & $1,152.8$ & 42.6 & 795.9 & 314.2 & 22.9 \\
\hline Paris Club ${ }^{5}$ & 813.0 & 25.5 & 796.9 & 29.5 & 513.5 & 31.8 & 2.3 \\
\hline Post-cutoff date & 303.6 & 9.5 & 293.2 & 10.8 & 292.9 & 23.5 & 1.7 \\
\hline Pre-cutoff date & 509.4 & 16.0 & 503.7 & 18.6 & 220.6 & 8.3 & 0.6 \\
\hline ODA & 136.1 & 4.3 & 133.7 & 4.9 & 116.3 & 0.0 & 0.0 \\
\hline Non-ODA & 373.3 & 11.7 & 370.0 & 13.7 & 104.4 & 8.3 & 0.6 \\
\hline \multicolumn{8}{|l|}{ By country: } \\
\hline Austria & 10.4 & 0.3 & 9.6 & 0.4 & $\ldots$ & $\ldots$ & $\ldots$ \\
\hline Belgium & 7.0 & 0.2 & 6.5 & 0.2 & $\cdots$ & $\begin{array}{l}\cdots \\
\cdots\end{array}$ & $\cdots$ \\
\hline Brazil & 10.9 & 0.3 & 9.6 & 0.4 & $\ldots$ & $\ldots$ & $\ldots$ \\
\hline Canada & 0.5 & 0.0 & 0.5 & 0.0 & $\ldots$ & $\ldots$ & $\ldots$ \\
\hline EEC-IDA administered loans & 2.2 & 0.1 & 1.4 & 0.1 & $\ldots$ & $\ldots$ & $\ldots$ \\
\hline France & 363.8 & 11.4 & 357.9 & 13.2 & $\ldots$ & $\ldots$ & $\ldots$ \\
\hline Germany & 4.6 & 0.1 & 4.9 & 0.2 & $\ldots$ & $\ldots$ & $\ldots$ \\
\hline Italy & 30.5 & 1.0 & 29.8 & 1.1 & $\ldots$ & $\ldots$ & $\ldots$ \\
\hline Japan & 96.0 & 3.0 & 94.9 & 3.5 & $\ldots$ & $\ldots$ & $\ldots$ \\
\hline Norway & 18.5 & 0.6 & 20.0 & 0.7 & $\ldots$ & $\ldots$ & $\ldots$ \\
\hline Russia & 145.4 & 4.6 & 141.8 & 5.2 & $\ldots$ & $\ldots$ & $\ldots$ \\
\hline Spain & 18.3 & 0.6 & 16.9 & 0.6 & $\ldots$ & $\ldots$ & $\ldots$ \\
\hline United Kingdom & 5.6 & 0.2 & 5.0 & 0.2 & $\ldots$ & $\ldots$ & $\ldots$ \\
\hline United States of America & 99.5 & 3.1 & 98.2 & 3.6 & $\ldots$ & $\ldots$ & $\ldots$ \\
\hline Other official bilateral & 329.7 & 10.3 & 271.3 & 10.0 & 210.2 & 210.2 & 15.3 \\
\hline Post-cutoff date & 188.5 & 5.9 & 149.8 & 5.5 & 149.3 & 149.3 & 10.9 \\
\hline Pre-cutoff date & 141.2 & 4.4 & 121.5 & 4.5 & 60.9 & 60.9 & 4.4 \\
\hline ODA & 55.7 & 1.7 & 35.9 & 1.3 & 34.9 & 34.9 & 2.5 \\
\hline Non-ODA & 85.6 & 2.7 & 85.6 & 3.2 & 26.0 & 26.0 & 1.9 \\
\hline \multicolumn{8}{|l|}{ By country: } \\
\hline Bulgaria & 10.8 & 0.3 & 10.8 & 0.4 & 2.7 & 2.7 & 0.2 \\
\hline China & 54.0 & 1.7 & 39.2 & 1.5 & 39.2 & 39.2 & 2.9 \\
\hline Congo, Rep. of & 50.0 & & 42.6 & & 42.6 & 42.6 & 3.1 \\
\hline Egypt & 0.0 & 0.0 & 0.0 & 0.0 & 0.0 & 0.0 & 0.0 \\
\hline Iraq & 6.1 & 0.2 & 6.1 & 0.2 & 1.5 & 1.5 & 0.1 \\
\hline Korea, DPR & 1.9 & 0.1 & 1.9 & 0.1 & 0.9 & 0.9 & 0.1 \\
\hline Kuwait & 74.4 & 2.3 & 53.8 & 2.0 & 53.7 & 53.7 & 3.9 \\
\hline Libya & 42.4 & 1.3 & 42.4 & 1.6 & 14.9 & 14.9 & 1.1 \\
\hline Morocco & 24.7 & 0.8 & 24.7 & 0.9 & 5.4 & 5.4 & 0.4 \\
\hline Romania & 1.4 & 0.0 & 1.4 & 0.1 & 1.3 & 1.3 & 0.1 \\
\hline Saudi Arabia & 62.4 & 2.0 & 46.9 & 1.7 & 46.8 & 46.8 & 3.4 \\
\hline Serbia & 0.3 & 0.0 & 0.3 & 0.0 & 0.2 & 0.2 & 0.0 \\
\hline Thailand & 1.4 & 0.0 & 1.4 & 0.1 & 0.9 & 0.9 & 0.1 \\
\hline Commercial & 85.0 & 2.7 & 84.6 & 3.1 & 72.2 & 72.2 & 5.3 \\
\hline
\end{tabular}

Sources: Guinean authorities, and World Bank and IMF staff estimates.

${ }^{1}$ Figures are based on data as of end-2011.

${ }^{2}$ Includes the 1989 Toronto, 1992 London, 1995 and 1997 Naples flows, as well as the 2001 and 2008 Cologne flows and interim relief from non-Paris Club creditors.

${ }^{3}$ Assumes full delivery of HIPC assistance as of end-2011.

${ }^{4}$ Arrears to the EU of USD 19.9 million were frozen in May 2011 and will be cleared after Completion Point. This arrears clearance will not be counted

toward the HIPC contribution and has therefore been left out of the table and calculations.

${ }^{5}$ Paris Club creditors deliver their share of assistance as a group. Actual delivery modalities are defined on a case-by-case basis. 
Table A4. Guinea: Revised Nominal and Present Value of Debt at Decision Point by

\section{Creditor Groups}

(As of end-1999) 1/

(In millions of U.S. dollars in end-June 1999 PV terms, unless otherwise indicated) ${ }^{2}$

\begin{tabular}{|c|c|c|c|c|c|c|}
\hline & \multicolumn{2}{|c|}{$\begin{array}{c}\text { Debt Outstanding } \\
\text { (PV terms) end-1999 (A) } \\
\end{array}$} & \multicolumn{2}{|c|}{$\begin{array}{c}\text { Debt Outstanding } \\
\text { (PV terms) Post-HIPC (B) }\end{array}$} & \multicolumn{2}{|c|}{$\begin{array}{c}\text { Reduction of the } \\
\text { PV of Debt due to HIPC (A-B) }\end{array}$} \\
\hline & $\begin{array}{r}\text { At decision } \\
\text { point } \\
\end{array}$ & $\begin{array}{r}\text { Revised at } \\
\text { completion point } \\
\end{array}$ & $\begin{array}{r}\text { At decision } \\
\text { point } \\
\end{array}$ & $\begin{array}{r}\text { Revised at } \\
\text { completion point } \\
\end{array}$ & $\begin{array}{r}\text { At decision } \\
\text { point } \\
\end{array}$ & $\begin{array}{r}\text { Revised at } \\
\text { completion point }\end{array}$ \\
\hline Total & 1,727 & 1,766 & 1,182 & 1,126 & 545 & 639 \\
\hline (as percent of exports) & 219 & 235 & 150 & 150 & 69 & 85 \\
\hline \multicolumn{7}{|l|}{ of which: } \\
\hline Multilateral & 1,039 & 1,058 & 711 & 675 & 328 & 383 \\
\hline Bilateral and Commercial & 688 & 708 & 471 & 451 & 217 & 256 \\
\hline Paris Club & 482 & 520 & 330 & 332 & 152 & 188 \\
\hline Other Official Bilateral & 198 & 180 & 136 & 115 & 63 & 65 \\
\hline Commercial & 8 & 8 & 5 & 5 & 2 & 3 \\
\hline \multicolumn{7}{|l|}{ Memorandum Items: } \\
\hline Common reduction factor (percent) ${ }^{3}$ & 31.6 & 36.2 & & & & \\
\hline 3-year exports average (millions of USD) ${ }^{6}$ & 788 & 751 & & & & \\
\hline
\end{tabular}

Sources: Guinean authorities, and World Bank and IMF staff estimates.

${ }^{1}$ Assumes proportional burden-sharing as described in "HIPC Initiative: Estimated Costs and Burden-Sharing Approaches" (IDA/SEC M97-306, 7/7/97), that is, after full application of traditional debt relief mechanisms.

2 Using six-month backward-looking discount rates at end-December 1999, and end-1999 exchange rates.

${ }^{3}$ After a hypothetical stock-of-debt operation on Naples terms at end-1999.

${ }^{4}$ Based on the latest data available at the completion point after full application of traditional debt relief mechanisms.

${ }^{5}$ Each creditor's PV reduction in percent of its exposure at the Decision Point reference date, end-December 1999.

${ }^{6}$ Based on the latest annual data on the three -year average of exports of goods and nonfactor services at the Decision Point. 
Table A5. Guinea: External Debt Service

(In millions of U.S. dollars, unless otherwise indicated)

\begin{tabular}{|c|c|c|c|c|c|c|c|c|c|c|}
\hline & \multicolumn{8}{|c|}{ Projections } & \multicolumn{2}{|c|}{ Annual Averages } \\
\hline & 2012 & 2013 & 2014 & 2015 & 2016 & 2021 & 2026 & 2031 & $2012-21$ & $2022-31$ \\
\hline \multicolumn{11}{|c|}{ I.Before traditional debt-relief mechanisms } \\
\hline Total & 203.6 & 176.9 & 177.0 & 174.9 & 165.2 & 137.4 & 172.7 & 186.6 & 163.8 & 171.7 \\
\hline Existing debt & 202.4 & 174.0 & 172.8 & 169.5 & 158.5 & 106.3 & 97.9 & 58.7 & 152.3 & 89.8 \\
\hline Multilateral & 109.2 & 106.9 & 106.1 & 103.5 & 101.4 & 88.9 & 87.1 & 55.8 & 100.0 & 79.5 \\
\hline World Bank & 52.4 & 53.1 & 53.5 & 54.3 & 55.5 & 57.4 & 58.6 & 35.8 & 55.4 & 53.1 \\
\hline $\mathrm{IMF}^{2}$ & 3.9 & 2.1 & 7.6 & 7.6 & 7.6 & 0.0 & 0.0 & 0.0 & 4.2 & 0.0 \\
\hline AfDB Group & 14.3 & 13.5 & 13.6 & 13.3 & 13.2 & 14.5 & 15.3 & 14.2 & 13.8 & 15.2 \\
\hline Other multilateral & 38.6 & 38.1 & 31.4 & 28.3 & 25.2 & 17.0 & 13.2 & 5.8 & 26.7 & 11.2 \\
\hline Official bilateral & 93.2 & 67.0 & 66.7 & 66.1 & 57.1 & 17.4 & 10.8 & 2.9 & 52.3 & 10.3 \\
\hline Paris Club & 52.8 & 53.2 & 53.3 & 53.7 & 45.6 & 7.4 & 5.6 & 0.0 & 38.6 & 4.6 \\
\hline Other official bilateral & 14.8 & 13.8 & 13.3 & 12.4 & 11.5 & 9.9 & 5.3 & 2.9 & 11.1 & 5.7 \\
\hline Commercial & 25.6 & 0.0 & 0.0 & 0.0 & 0.0 & 0.0 & 0.0 & 0.0 & 2.6 & 0.0 \\
\hline New debt & 1.2 & 3.0 & 4.3 & 5.4 & 6.7 & 31.1 & 74.8 & 127.9 & 11.5 & 81.9 \\
\hline Debt service-to-exports ratio & 13.3 & 11.0 & 10.6 & 8.1 & 5.2 & 1.6 & 1.9 & 1.9 & 5.9 & 1.9 \\
\hline Debt service-to-revenue ratio & 18.5 & 14.1 & 13.8 & 11.1 & 9.0 & 5.1 & 4.9 & 3.8 & 9.9 & 4.7 \\
\hline \multicolumn{11}{|c|}{ II. After traditional debt-relief mechanisms ${ }^{1}$} \\
\hline Total & 191.0 & 164.9 & 166.2 & 165.1 & 167.9 & 174.5 & 178.7 & 202.0 & 170.5 & 183.2 \\
\hline Existing debt & 189.9 & 161.9 & 161.9 & 159.7 & 161.2 & 143.4 & 103.9 & 74.1 & 159.0 & 101.3 \\
\hline Multilateral & 109.2 & 106.9 & 106.1 & 103.5 & 101.4 & 88.9 & 87.1 & 55.8 & 100.0 & 79.5 \\
\hline World Bank & 52.4 & 53.1 & 53.5 & 54.3 & 55.5 & 57.4 & 58.6 & 35.8 & 55.4 & 53.1 \\
\hline $\mathrm{IMF}^{2}$ & 3.9 & 2.1 & 7.6 & 7.6 & 7.6 & 0.0 & 0.0 & 0.0 & 4.2 & 0.0 \\
\hline AfDB Group & 14.3 & 13.5 & 13.6 & 13.3 & 13.2 & 14.5 & 15.3 & 14.2 & 13.8 & 15.2 \\
\hline Other multilateral & 38.6 & 38.1 & 31.4 & 28.3 & 25.2 & 17.0 & 13.2 & 5.8 & 26.7 & 11.2 \\
\hline Official bilateral & 80.6 & 55.0 & 55.8 & 56.2 & 59.8 & 54.5 & 16.9 & 18.3 & 59.0 & 21.8 \\
\hline Paris Club & 37.3 & 38.0 & 39.0 & 40.1 & 42.9 & 36.0 & 7.9 & 9.7 & 39.9 & 11.5 \\
\hline Other official bilateral & 17.5 & 16.7 & 16.6 & 15.9 & 16.6 & 18.0 & 8.9 & 8.6 & 16.3 & 10.3 \\
\hline Commercial & 25.8 & 0.2 & 0.2 & 0.3 & 0.3 & 0.5 & 0.0 & 0.0 & 2.9 & 0.1 \\
\hline New debt & 1.2 & 3.0 & 4.3 & 5.4 & 6.7 & 31.1 & 74.8 & 127.9 & 11.5 & 81.9 \\
\hline Debt service-to-exports ratio & 12.5 & 10.2 & 10.0 & 7.6 & 5.3 & 2.1 & 2.0 & 2.1 & 5.8 & 2.0 \\
\hline Debt service-to-revenue ratio & 17.4 & 13.1 & 13.0 & 10.5 & 9.2 & 6.5 & 5.1 & 4.1 & 10.0 & 5.0 \\
\hline \multicolumn{11}{|c|}{ III. After enhanced HIPC assistance } \\
\hline Total & 151.0 & 104.9 & 98.8 & 113.7 & 111.2 & 131.0 & 174.0 & 205.4 & 119.9 & 177.8 \\
\hline Existing debt & 149.9 & 101.9 & 94.5 & 108.3 & 104.5 & 99.9 & 99.3 & 77.5 & 108.4 & 95.9 \\
\hline Multilateral & 86.4 & 28.4 & 29.0 & 31.9 & 32.5 & 70.6 & 78.7 & 61.3 & 42.9 & 74.5 \\
\hline World Bank & 41.9 & 22.8 & 23.1 & 23.6 & 24.3 & 57.4 & 58.6 & 35.8 & 29.5 & 53.1 \\
\hline $\mathrm{IMF}^{2}$ & 2.0 & 0.0 & 0.1 & 0.1 & 0.0 & 0.0 & 0.0 & 0.0 & 0.6 & 0.0 \\
\hline AfDB Group & 14.0 & 3.2 & 3.4 & 3.3 & 3.3 & 4.2 & 5.4 & 14.2 & 4.6 & 8.3 \\
\hline Other multilateral & 28.5 & 2.5 & 2.5 & 4.9 & 4.8 & 9.0 & 14.8 & 11.3 & 8.3 & 13.0 \\
\hline Official bilateral & 63.5 & 73.5 & 65.5 & 76.4 & 72.0 & 29.3 & 20.5 & 16.2 & 65.5 & 21.4 \\
\hline Paris Club & 31.9 & 60.6 & 52.7 & 64.1 & 59.5 & 13.9 & 8.6 & 4.8 & 50.4 & 8.8 \\
\hline Other official bilateral & 6.2 & 12.3 & 12.2 & 11.6 & 11.8 & 14.5 & 10.5 & 9.2 & 11.9 & 11.1 \\
\hline Commercial & 25.4 & 0.6 & 0.6 & 0.6 & 0.6 & 0.9 & 1.4 & 2.3 & 3.2 & 1.5 \\
\hline New debt & 1.2 & 3.0 & 4.3 & 5.4 & 6.7 & 31.1 & 74.8 & 127.9 & 11.5 & 81.9 \\
\hline Debt service-to-exports ratio & 9.9 & 6.5 & 5.9 & 5.3 & 3.5 & 1.6 & 1.9 & 2.1 & 4.0 & 1.9 \\
\hline Debt service-to-revenue ratio & 13.7 & 8.3 & 7.7 & 7.2 & 6.1 & 4.9 & 4.9 & 4.2 & 7.0 & 4.8 \\
\hline \multicolumn{11}{|c|}{ Reduction in debt service as a result of } \\
\hline HIPC Initiative assistance ${ }^{2}$ & 40.0 & 60.0 & 67.4 & 51.4 & 56.7 & 43.5 & 4.7 & -3.4 & 50.6 & 5.4 \\
\hline \multicolumn{11}{|c|}{ IV. After enhanced HIPC and MDRI assistance } \\
\hline Total & 145.2 & 84.7 & 78.2 & 92.9 & 89.8 & 76.6 & 120.2 & 165.3 & 96.6 & 126.4 \\
\hline Existing debt & 144.0 & 81.8 & 74.0 & 87.5 & 83.1 & 45.5 & 45.4 & 37.4 & 85.1 & 44.5 \\
\hline Multilateral & 80.5 & 8.3 & 8.5 & 11.1 & 11.1 & 16.3 & 24.9 & 21.2 & 19.6 & 23.1 \\
\hline World Bank & 36.2 & 3.5 & 3.6 & 3.9 & 4.0 & 4.5 & 6.6 & 6.4 & 7.2 & 6.4 \\
\hline $\mathrm{IMF}^{2}$ & 2.0 & 0.0 & 0.1 & 0.1 & 0.0 & 0.0 & 0.0 & 0.0 & 0.6 & 0.0 \\
\hline AfDB Group & 13.8 & 2.3 & 2.3 & 2.3 & 2.3 & 2.8 & 3.6 & 3.5 & 3.5 & 3.6 \\
\hline Other multilateral & 28.5 & 2.5 & 2.5 & 4.9 & 4.8 & 9.0 & 14.8 & 11.3 & 8.3 & 13.0 \\
\hline Official bilateral & 63.5 & 73.5 & 65.5 & 76.4 & 72.0 & 29.3 & 20.5 & 16.2 & 65.5 & 21.4 \\
\hline Paris Club & 31.9 & 60.6 & 52.7 & 64.1 & 59.5 & 13.9 & 8.6 & 4.8 & 50.4 & 8.8 \\
\hline Other official bilateral & 6.2 & 12.3 & 12.2 & 11.6 & 11.8 & 14.5 & 10.5 & 9.2 & 11.9 & 11.1 \\
\hline Commercial & 25.4 & 0.6 & 0.6 & 0.6 & 0.6 & 0.9 & 1.4 & 2.3 & 3.2 & 1.5 \\
\hline New debt & 1.2 & 3.0 & 4.3 & 5.4 & 6.7 & 31.1 & 74.8 & 127.9 & 11.5 & 81.9 \\
\hline Debt service-to-exports ratio & 9.5 & 5.3 & 4.7 & 4.3 & 2.8 & 0.9 & 1.3 & 1.7 & 3.4 & 1.4 \\
\hline Debt service-to-revenue ratio & 13.2 & 6.7 & 6.1 & 5.9 & 4.9 & 2.8 & 3.4 & 3.4 & 5.7 & 3.4 \\
\hline \multicolumn{11}{|c|}{ Reduction in debt service as a result of } \\
\hline MDRI assistance ${ }^{3}$ & 5.9 & 20.1 & 20.5 & 20.8 & 21.4 & 54.4 & 53.8 & 40.1 & 23.3 & 51.4 \\
\hline
\end{tabular}


Table A5. Guinea: External Debt Service (concluded)

(In millions of U.S. dollars, unless otherwise indicated)

\begin{tabular}{|c|c|c|c|c|c|c|c|c|c|c|}
\hline & \multicolumn{8}{|c|}{ Projections } & \multicolumn{2}{|c|}{ Annual Averages } \\
\hline & 2012 & 2013 & 2014 & 2015 & 2016 & 2021 & 2026 & 2031 & $2012-21$ & 2022-31 \\
\hline \multicolumn{11}{|c|}{ V. After enhanced HIPC, MDRI and bilateral beyond HIPC assistance ${ }^{4}$} \\
\hline Total & 128.1 & 26.3 & 27.2 & 30.8 & 32.1 & 63.1 & 112.1 & 160.8 & 49.3 & 118.1 \\
\hline Existing debt & 127.0 & 23.3 & 23.0 & 25.4 & 25.4 & 32.0 & 37.3 & 32.9 & 37.8 & 36.2 \\
\hline Multilateral & 80.5 & 8.3 & 8.5 & 11.1 & 11.1 & 16.3 & 24.9 & 21.2 & 19.6 & 23.1 \\
\hline World Bank & 36.2 & 3.5 & 3.6 & 3.9 & 4.0 & 4.5 & 6.6 & 6.4 & 7.2 & 6.4 \\
\hline $\mathrm{IMF}^{2}$ & 2.0 & 0.0 & 0.1 & 0.1 & 0.0 & 0.0 & 0.0 & 0.0 & 0.6 & 0.0 \\
\hline AfDB Group & 13.8 & 2.3 & 2.3 & 2.3 & 2.3 & 2.8 & 3.6 & 3.5 & 3.5 & 3.6 \\
\hline Other multilateral & 28.5 & 2.5 & 2.5 & 4.9 & 4.8 & 9.0 & 14.8 & 11.3 & 8.3 & 13.0 \\
\hline Official bilateral & 46.5 & 15.1 & 14.5 & 14.3 & 14.2 & 15.8 & 12.4 & 11.7 & 18.2 & 13.1 \\
\hline Paris Club & 14.9 & 2.1 & 1.7 & 2.0 & 2.0 & 0.4 & 0.4 & 0.2 & 3.2 & 0.4 \\
\hline Other official bilateral & 6.2 & 12.3 & 12.2 & 11.6 & 11.6 & 14.5 & 10.5 & 9.3 & 11.8 & 11.1 \\
\hline Commercial & 25.4 & 0.6 & 0.6 & 0.6 & 0.6 & 0.9 & 1.4 & 2.3 & 3.2 & 1.5 \\
\hline New debt & 1.2 & 3.0 & 4.3 & 5.4 & 6.7 & 31.1 & 74.8 & 127.9 & 11.5 & 81.9 \\
\hline Debt service-to-exports ratio & 8.4 & 1.6 & 1.6 & 1.4 & 1.0 & 0.7 & 1.2 & 1.7 & 1.8 & 1.3 \\
\hline Debt service-to-revenue ratio & 11.6 & 2.1 & 2.1 & 2.0 & 1.8 & 2.3 & 3.2 & 3.3 & 3.0 & 3.1 \\
\hline \multicolumn{11}{|l|}{ Memorandum items: } \\
\hline Exports of goods \& services (3-year mvg. avg. $)^{5}$ & 1,526 & 1,609 & 1,669 & 2,162 & 3,195 & 8,441 & 9,124 & 9,675 & 4,476 & 9,232 \\
\hline Government revenue $^{6}$ & 1,101 & 1,257 & 1,282 & 1,577 & 1,831 & 2,690 & 3,527 & 4,904 & 1,881 & 3,711 \\
\hline
\end{tabular}

Sources: Guinean authorities, and World Bank and IMF staff estimates and projections.

${ }^{1}$ Assumes a stock-of-debt operation on Naples terms (67 percent PV reduction) as of end of 2011, and at least comparable action by other official bilateral and commercial creditors.

${ }^{2}$ The reduction is measured as the difference between the projected debt service after full use of traditional debt relief and debt service after the application of HIPC relief.

${ }^{3}$ The reduction is measured as the difference between the projected debt service after application of HIPC relief and after application of MDRI relief.

${ }^{4}$ Includes additional debt relief provided on a voluntary basis by the Paris Club beyond the requirements of the enhanced HIPC framework as specified in Table 12A.

${ }^{5}$ As defined in IMF, Balance of Payments Manual, 5th edition, 1993.

${ }^{6}$ Revenue is defined as central government revenue, excluding grants. 
Table A6. Guinea: Present Value of External Debt 1/

(In millions of U.S. dollars, unless otherwise indicated)

\begin{tabular}{|c|c|c|c|c|c|c|c|c|c|c|c|}
\hline \multirow{3}{*}{\multicolumn{2}{|c|}{2011}} & \multicolumn{8}{|c|}{ Projections } & \multirow{2}{*}{\multicolumn{2}{|c|}{$\frac{\text { Annual Averages }}{2012-212022-31}$}} \\
\hline & & \multirow[t]{2}{*}{2012} & \multirow[t]{2}{*}{2013} & \multirow{2}{*}{2014} & \multirow[t]{2}{*}{2015} & \multirow[t]{2}{*}{2016} & \multirow[t]{2}{*}{2021} & \multirow[t]{2}{*}{2026} & \multirow[t]{2}{*}{2031} & & \\
\hline & & & & & & & & & & & \\
\hline $\mathrm{PV}$ of total debt & 2,715 & 2,683 & 2,631 & 2,573 & 2,506 & 2,475 & 2,780 & 2,816 & 2,379 & 2,601 & 2,715 \\
\hline PV of outstanding debt & 2,715 & 2,575 & 2,460 & 2,342 & 2,224 & 2,114 & 1,660 & 1,274 & 966 & 2,084 & 1,252 \\
\hline Multilateral & 1,551 & 1,488 & 1,426 & 1,362 & 1,299 & 1,236 & 927 & 598 & 318 & 1,205 & 575 \\
\hline World Bank & 897 & 872 & 846 & 819 & 790 & 759 & 580 & 358 & 167 & 736 & 341 \\
\hline IMF & 37 & 34 & 33 & 26 & 19 & 12 & 0 & 0 & 0 & 13 & 0 \\
\hline AfDB Group & 302 & 295 & 289 & 282 & 276 & 270 & 232 & 180 & 127 & 265 & 175 \\
\hline Other multilateral & 316 & 287 & 258 & 235 & 214 & 195 & 115 & 60 & 25 & 191 & 59 \\
\hline Official bilateral and commercial & 1,163 & 1,087 & 1,034 & 980 & 925 & 878 & 733 & 676 & 648 & 879 & 676 \\
\hline Paris Club & 798 & 757 & 714 & 670 & 624 & 584 & 472 & 440 & 431 & 586 & 442 \\
\hline Other official bilateral & 304 & 293 & 284 & 274 & 265 & 257 & 225 & 200 & 181 & 256 & 198 \\
\hline Commercial & 61 & 37 & 37 & 37 & 37 & 37 & 37 & 37 & 37 & 37 & 37 \\
\hline $\mathrm{PV}$ of new borrowing & & 108 & 171 & 230 & 281 & 361 & 1,120 & 1,542 & 1,413 & 517 & 1,463 \\
\hline \multicolumn{12}{|c|}{ II. After traditional debt-relief mechanisms ${ }^{2}$} \\
\hline PV of total debt & 2,309 & 2,296 & 2,263 & 2,223 & 2,173 & 2,148 & 2,385 & 2,393 & 1,922 & 2,248 & 2,282 \\
\hline PV of outstanding debt & 2,309 & 2,188 & 2,092 & 1,992 & 1,892 & 1,787 & 1,264 & 851 & 510 & 1,731 & 819 \\
\hline Multilateral & 1,551 & 1,488 & 1,426 & 1,362 & 1,299 & 1,236 & 927 & 598 & 318 & 1,205 & 575 \\
\hline World Bank & 897 & 872 & 846 & 819 & 790 & 759 & 580 & 358 & 167 & 736 & 341 \\
\hline IMF & 37 & 34 & 33 & 26 & 19 & 12 & 0 & 0 & 0 & 13 & 0 \\
\hline AfDB Group & 302 & 295 & 289 & 282 & 276 & 270 & 232 & 180 & 127 & 265 & 175 \\
\hline Other multilateral & 316 & 287 & 258 & 235 & 214 & 195 & 115 & 60 & 25 & 191 & 59 \\
\hline Official bilateral and commercial & 758 & 700 & 666 & 630 & 593 & 551 & 337 & 253 & 192 & 526 & 244 \\
\hline Paris Club & 459 & 435 & 411 & 385 & 357 & 325 & 165 & 115 & 86 & 306 & 111 \\
\hline Other official bilateral & 245 & 235 & 226 & 216 & 207 & 197 & 145 & 111 & 78 & 192 & 106 \\
\hline Commercial & 55 & 30 & 30 & 29 & 29 & 29 & 27 & 27 & 27 & 29 & 27 \\
\hline $\mathrm{PV}$ of new borrowing & & 108 & 171 & 230 & 281 & 361 & 1,120 & 1,542 & 1,413 & 517 & 1,463 \\
\hline \multicolumn{12}{|c|}{ III. After conditional delivery of enhanced HIPC assistance ${ }^{3}$} \\
\hline PV of total debt & 2,600 & 1,867 & 1,881 & 1,897 & 1,889 & 1,912 & 2,356 & 2,418 & 1,954 & 2,025 & 2,308 \\
\hline PV of outstanding debt & 2,600 & 1,759 & 1,711 & 1,667 & 1,608 & 1,551 & 1,236 & 876 & 541 & 1,508 & 845 \\
\hline Multilateral & 1,549 & 1,004 & 1,005 & 1,006 & 1,005 & 1,002 & 928 & 655 & 384 & 989 & 628 \\
\hline World Bank & 897 & 655 & 652 & 649 & 646 & 642 & 580 & 358 & 167 & 634 & 341 \\
\hline IMF & 35 & 3 & 3 & 3 & 3 & 3 & 0 & 0 & 0 & 2 & 0 \\
\hline AfDB Group & 302 & 164 & 165 & 166 & 166 & 167 & 170 & 163 & 127 & 167 & 156 \\
\hline Other multilateral & 316 & 182 & 185 & 188 & 189 & 190 & 178 & 134 & 91 & 186 & 131 \\
\hline Official bilateral and commercial & 1,051 & 755 & 705 & 660 & 603 & 549 & 308 & 221 & 157 & 519 & 217 \\
\hline Paris Club & 695 & 497 & 452 & 414 & 362 & 314 & 112 & 65 & 47 & 289 & 67 \\
\hline Other official bilateral & 271 & 210 & 205 & 199 & 193 & 187 & 148 & 110 & 72 & 182 & 106 \\
\hline Commercial & 85 & 48 & 48 & 48 & 48 & 48 & 48 & 45 & 38 & 48 & 44 \\
\hline $\mathrm{PV}$ of new borrowing & & 108 & 171 & 230 & 281 & 361 & 1,120 & 1,542 & 1,413 & 517 & 1,463 \\
\hline \multicolumn{12}{|c|}{ IV. After unconditional delivery of enhanced HIPC assistance ${ }^{4}$} \\
\hline PV of total debt & 1,855 & 1,867 & 1,881 & 1,897 & 1,889 & 1,912 & 2,356 & 2,418 & 1,954 & 2,025 & 2,308 \\
\hline PV of outstanding debt & 1,855 & 1,759 & 1,711 & 1,667 & 1,608 & 1,551 & 1,236 & 876 & 541 & 1,508 & 845 \\
\hline Multilateral & 1,059 & 1,004 & 1,005 & 1,006 & 1,005 & 1,002 & 928 & 655 & 384 & 989 & 628 \\
\hline World Bank & 676 & 655 & 652 & 649 & 646 & 642 & 580 & 358 & 167 & 634 & 341 \\
\hline IMF & 5 & 3 & 3 & 3 & 3 & 3 & 0 & 0 & 0 & 2 & 0 \\
\hline AfDB Group & 174 & 164 & 165 & 166 & 166 & 167 & 170 & 163 & 127 & 167 & 156 \\
\hline Others & 204 & 182 & 185 & 188 & 189 & 190 & 178 & 134 & 91 & 186 & 131 \\
\hline Official bilateral and commercial & 796 & 755 & 705 & 660 & 603 & 549 & 308 & 221 & 157 & 519 & 217 \\
\hline Paris Club & 514 & 497 & 452 & 414 & 362 & 314 & 112 & 65 & 47 & 289 & 67 \\
\hline Other official bilateral & 210 & 210 & 205 & 199 & 193 & 187 & 148 & 110 & 72 & 182 & 106 \\
\hline Commercial & 72 & 48 & 48 & 48 & 48 & 48 & 48 & 45 & 38 & 48 & 44 \\
\hline PV of new borrowing & & 108 & 171 & 230 & 281 & 361 & 1,120 & 1,542 & 1,413 & 517 & 1,463 \\
\hline
\end{tabular}


Table A6. Guinea: Present Value of External Debt 1/(concluded)

(In millions of U.S. dollars, unless otherwise indicated)

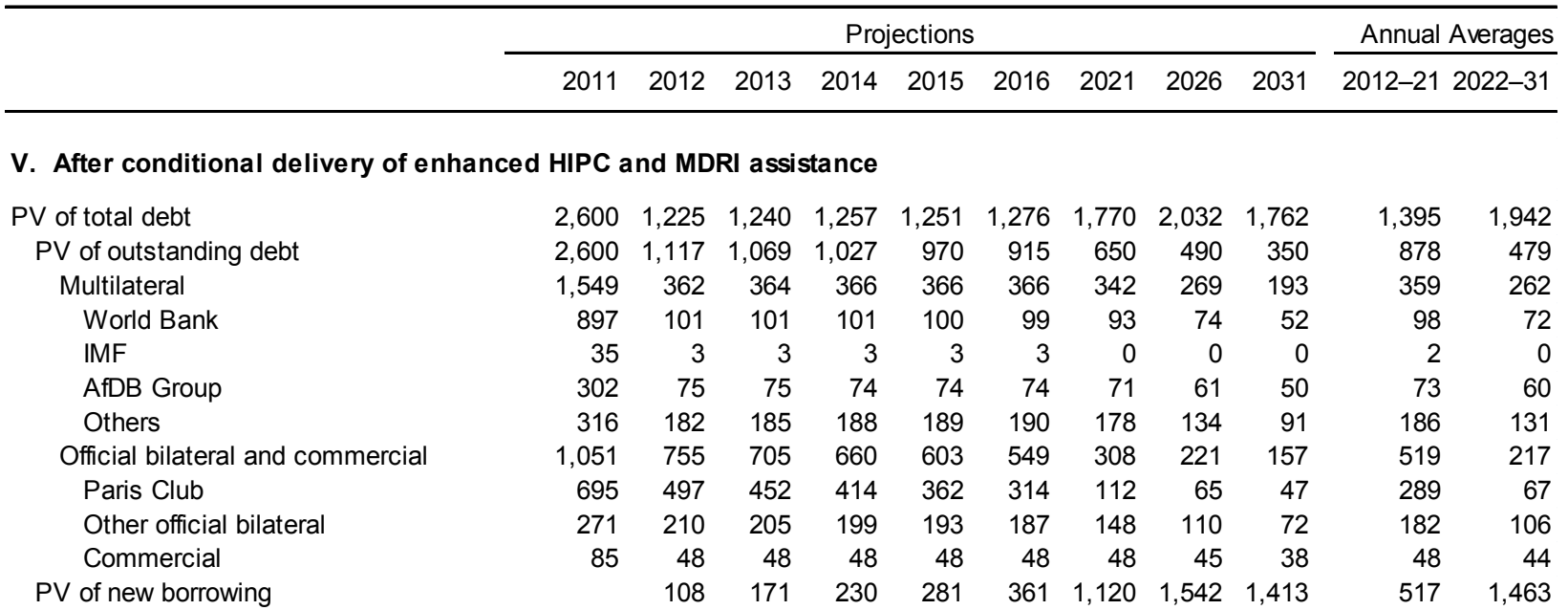

VI. After conditional delivery of enhanced HIPC and MDRI assistance and bilateral beyond HIPC assistance

\begin{tabular}{|c|c|c|c|c|c|c|c|c|c|c|c|}
\hline PV of total debt & 2,600 & 746 & 804 & 859 & 902 & 974 & 1,663 & 1,970 & 1,716 & 1,118 & 1,878 \\
\hline PV of outstanding debt & 2,600 & 638 & 633 & 628 & 621 & 613 & 543 & 428 & 304 & 600 & 414 \\
\hline Multilateral & 1,549 & 362 & 364 & 366 & 366 & 366 & 342 & 269 & 193 & 359 & 262 \\
\hline World Bank & 897 & 101 & 101 & 101 & 100 & 99 & 93 & 74 & 52 & 98 & 72 \\
\hline IMF & 35 & 3 & 3 & 3 & 3 & 3 & 0 & 0 & 0 & 2 & 0 \\
\hline AfDB Group & 302 & 75 & 75 & 74 & 74 & 74 & 71 & 61 & 50 & 73 & 60 \\
\hline Others & 316 & 182 & 185 & 188 & 189 & 190 & 178 & 134 & 91 & 186 & 131 \\
\hline Official bilateral and commercial & 1,051 & 276 & 269 & 262 & 255 & 247 & 201 & 158 & 111 & 241 & 152 \\
\hline Paris Club & 695 & 18 & 16 & 15 & 14 & 12 & 4 & 2 & 0 & 11 & 2 \\
\hline Other official bilateral & 271 & 210 & 205 & 199 & 193 & 187 & 149 & 111 & 73 & 183 & 106 \\
\hline Commercial & 85 & 48 & 48 & 48 & 48 & 48 & 48 & 45 & 38 & 48 & 44 \\
\hline PV of new borrowing & & 108 & 171 & 230 & 281 & 361 & 1,120 & 1,542 & 1,413 & 517 & 1,463 \\
\hline
\end{tabular}

\section{Memorandum items:}

\section{After unconditional delivery of enhanced HIPC and bilateral beyond HIPC assistance}

\begin{tabular}{|c|c|c|c|c|c|c|c|c|c|c|c|}
\hline PV of total debt & 1,373 & 1,388 & 1,445 & 1,499 & 1,540 & 1,610 & 2,249 & 2,356 & 1,907 & 1,747 & 2,244 \\
\hline PV of outstanding debt & 1,373 & 1,280 & 1,274 & 1,268 & 1,259 & 1,249 & 1,129 & 814 & 495 & 1,230 & 781 \\
\hline Multilateral & 1,059 & 1,004 & 1,005 & 1,006 & 1,005 & 1,002 & 928 & 655 & 384 & 989 & 628 \\
\hline Official bilateral and commercial & 314 & 276 & 269 & 262 & 255 & 247 & 201 & 158 & 111 & 241 & 152 \\
\hline Paris Club & 32 & 18 & 16 & 15 & 14 & 12 & 4 & 2 & 0 & 11 & 2 \\
\hline Other official bilateral & 210 & 210 & 205 & 199 & 193 & 187 & 149 & 111 & 73 & 183 & 106 \\
\hline Commercial & 72 & 48 & 48 & 48 & 48 & 48 & 48 & 45 & 38 & 48 & 44 \\
\hline PV of new borrowing & & 108 & 171 & 230 & 281 & 361 & 1,120 & 1,542 & 1,413 & 517 & 1,463 \\
\hline
\end{tabular}

Sources: Guinean authorities, and World Bank and IMF staff estimates and projections.

${ }^{1}$ Refers to public and publicly guaranteed external debt only and is discounted on the basis of the average commercial interest reference rate for the respective currency, derived over the six-month period prior to the latest date for which actual data are available (December 2011, see Table A1).

${ }^{2}$ Assumes a stock-of-debt operation on Naples terms (67 percent PV reduction) as of end-2011, and at least comparable action by other official bilateral and commercial creditors.

${ }^{3}$ Assumes interim relief under the enhanced HIPC Initiative from December 2000 to September 2012 and full delivery of assistance at Completion Point.

${ }^{4}$ Assumes full delivery of estimated HIPC initiative debt relief at end-2011.

${ }^{5}$ Includes additional debt relief provided on a voluntary basis by the Paris Club beyond the requirements of the enhanced HIPC framework as specified on Table A11. 
Table A7. Guinea: Key External Debt Indicators, 2011-31

(In millions of U.S. dollars, unless otherwise indicated)

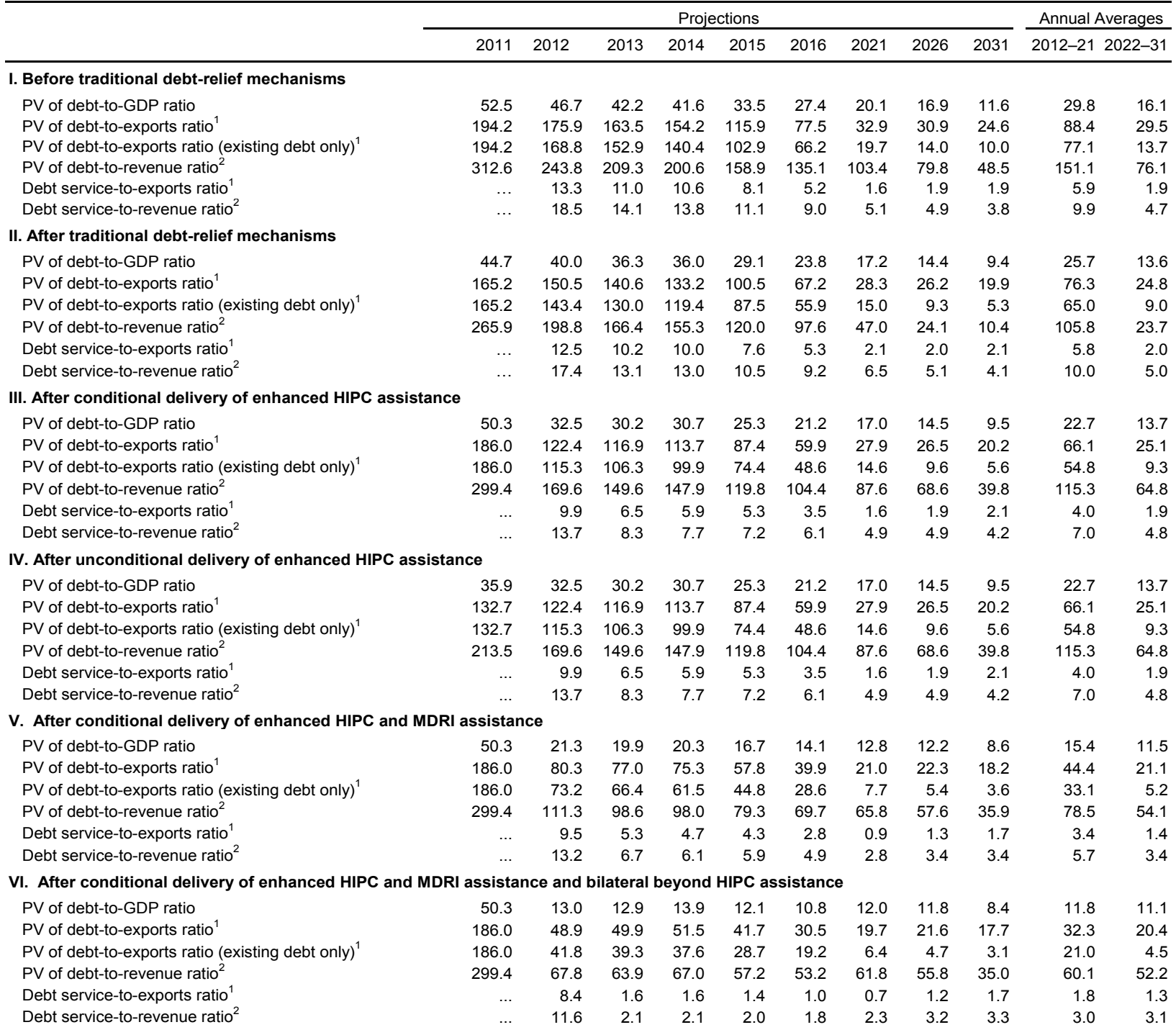

Memorandum items:

VII. After unconditional delivery of enhanced HIPC and bilateral beyond HIPC assistance ${ }^{3}$

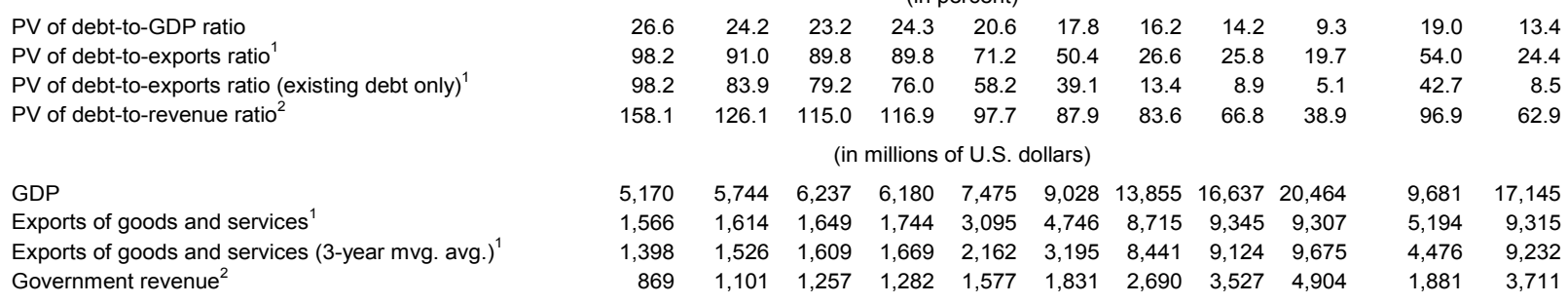

\footnotetext{
Sources: Guinean authorities, and World Bank and IMF staff estimates and projections.

${ }^{1}$ Based on a three-year moving average of exports of goods and services, as defined in IMF, Balance of Payments Manual, 5th edition, 1993

${ }^{2}$ Revenue is defined as central government revenue, excluding grants.

${ }^{3}$ The PV of debt-to-exports ratio after unconditional delivery of enhanced HIPC and additional bilateral beyond HIPC assistance is the base for assessing whether topping-up assistance is warranted. The ratio at end-2011 also appears in text Table 2.
} 
Table A8. Guinea: Sensitivity Analysis, 2011-31 1/ (In percent, unless otherwise indicated)

\begin{tabular}{|c|c|c|c|c|c|c|c|c|c|c|c|}
\hline & \multicolumn{9}{|c|}{ Projections } & \multicolumn{2}{|c|}{ Annual Averages } \\
\hline & 2011 & 2012 & 2013 & 2014 & 2015 & 2016 & 2021 & 2026 & 2031 & $2012-21$ & 2022-31 \\
\hline \multicolumn{12}{|l|}{ I. Baseline scenario } \\
\hline PV of debt-to-GDP ratio & 50.3 & 13.0 & 12.9 & 13.9 & 12.1 & 10.8 & 12.0 & 11.8 & 8.4 & 11.8 & 11.1 \\
\hline PV of debt-to-exports ratio ${ }^{2}$ & 186.0 & 48.9 & 49.9 & 51.5 & 41.7 & 30.5 & 19.7 & 21.6 & 17.7 & 32.3 & 20.4 \\
\hline PV of debt-to-revenue ratio ${ }^{3}$ & 299.4 & 67.8 & 63.9 & 67.0 & 57.2 & 53.2 & 61.8 & 55.8 & 35.0 & 60.1 & 52.2 \\
\hline Debt service-to-exports ratio ${ }^{2}$ & $\ldots$ & 8.4 & 1.6 & 1.6 & 1.4 & 1.0 & 0.7 & 1.2 & 1.7 & 1.8 & 1.3 \\
\hline Debt service-to-revenue ratio ${ }^{3}$ & $\ldots$ & 11.6 & 2.1 & 2.1 & 2.0 & 1.8 & 2.3 & 3.2 & 3.3 & 3.0 & 3.1 \\
\hline \multicolumn{12}{|l|}{ II. Permanently lower GDP growth } \\
\hline PV of debt-to-GDP ratio & 50.3 & 13.0 & 13.2 & 14.5 & 12.9 & 11.7 & 14.6 & 16.2 & 12.9 & 13.0 & 15.3 \\
\hline PV of debt-to-exports ratio ${ }^{2}$ & 186.0 & 48.9 & 49.9 & 51.5 & 41.7 & 30.5 & 19.7 & 21.6 & 17.7 & 32.3 & 20.4 \\
\hline PV of debt-to-revenue ratio ${ }^{3}$ & 299.4 & 67.8 & 64.6 & 68.4 & 59.0 & 55.5 & 68.2 & 65.2 & 43.2 & 63.0 & 61.0 \\
\hline Debt service-to-exports ratio ${ }^{2}$ & $\ldots$ & 8.4 & 1.6 & 1.6 & 1.4 & 1.0 & 0.7 & 1.2 & 1.7 & 1.8 & 1.3 \\
\hline Debt service-to-revenue ratio ${ }^{3}$ & $\ldots$ & 11.6 & 2.1 & 2.2 & 2.0 & 1.8 & 2.6 & 3.7 & 4.1 & 3.1 & 3.7 \\
\hline \multicolumn{12}{|c|}{ III. Permanently lower exports growth } \\
\hline PV of debt-to-GDP ratio & 50.3 & 13.0 & 12.9 & 13.9 & 13.7 & 13.9 & 18.1 & 18.7 & 13.9 & 14.9 & 17.6 \\
\hline PV of debt-to-exports ratio ${ }^{2}$ & 186.0 & 48.9 & 49.9 & 51.5 & 46.0 & 39.4 & 35.4 & 40.7 & 35.2 & 40.7 & 38.6 \\
\hline PV of debt-to-revenue ratio ${ }^{3}$ & 299.4 & 67.8 & 63.9 & 67.0 & 60.3 & 56.3 & 64.5 & 57.8 & 35.9 & 62.1 & 54.0 \\
\hline Debt service-to-exports ratio ${ }^{2}$ & $\ldots$ & 8.4 & 1.6 & 1.6 & 1.6 & 1.3 & 1.3 & 2.3 & 3.3 & 2.1 & 2.4 \\
\hline Debt service-to-revenue ratio ${ }^{3}$ & $\ldots$ & 11.6 & 2.1 & 2.1 & 2.1 & 1.9 & 2.4 & 3.3 & 3.4 & 3.1 & 3.2 \\
\hline \multicolumn{12}{|c|}{ IV. Lower average concessionality on new borrowing } \\
\hline PV of debt-to-GDP ratio & 50.3 & 13.6 & 13.7 & 14.8 & 12.8 & 11.5 & 12.5 & 10.5 & 6.4 & 12.5 & 9.9 \\
\hline PV of debt-to-exports ratio ${ }^{2}$ & 186.0 & 51.1 & 53.1 & 54.9 & 44.4 & 32.4 & 20.5 & 19.2 & 13.5 & 34.3 & 18.1 \\
\hline PV of debt-to-revenue ratio ${ }^{3}$ & 299.4 & 70.9 & 68.0 & 71.5 & 60.9 & 56.6 & 64.5 & 49.7 & 26.7 & 63.7 & 46.8 \\
\hline Debt service-to-exports ratio ${ }^{2}$ & $\ldots$ & 8.5 & 1.9 & 2.4 & 2.2 & 1.7 & 1.5 & 2.0 & 1.8 & 2.3 & 1.9 \\
\hline Debt service-to-revenue ratio ${ }^{3}$ & $\ldots$ & 11.8 & 2.4 & 3.1 & 3.1 & 2.9 & 4.8 & 5.2 & 3.5 & 4.3 & 4.8 \\
\hline
\end{tabular}

Sources: Guinean authorities, and World Bank and IMF staff estimates and projections.

' All debt indicators are defined after conditional delivery of enhanced HIPC and MDRI assistance and bilateral beyond HIPC assistance (item VI of Table A7)

¿Based on a three-year moving average of exports of goods and services, as defined in IMF, Balance of Payments Manual, 5th edition, 1993.

${ }^{\circ}$ Revenue is defined as central government revenue, excluding grants. 
Table A9. Guinea: Delivery of IDA Assistance Under the Enhanced HIPC Initiative and the MDRI, 2012-45

(In millions of U.S. dollars, unless otherwise indicated)

\begin{tabular}{|c|c|c|c|c|c|c|c|c|c|c|c|c|c|c|c|c|}
\hline & \multirow{2}{*}{\multicolumn{2}{|c|}{2012}} & \multirow{2}{*}{2012} & \multirow[b]{2}{*}{2013} & \multirow[b]{2}{*}{2014} & \multirow[b]{2}{*}{2015} & \multirow[b]{2}{*}{2016} & \multirow{2}{*}{2017} & \multirow{2}{*}{2018} & \multirow{2}{*}{2019} & \multirow{2}{*}{2020} & \multirow{2}{*}{2025} & \multirow{2}{*}{2035} & \multirow{2}{*}{2045} & \multicolumn{2}{|c|}{ Cumulative } \\
\hline & & & & & & & & & & & & & & & 2012-2020 & $2012-45$ \\
\hline & & & & & & & & & & & & & & & & \\
\hline \multicolumn{17}{|l|}{ I. Relief under the Enhanced HIPC Initiative } \\
\hline Debt service before HIPC assistance ${ }^{1}$ & 35.9 & 16.5 & 52.4 & 53.1 & 53.5 & 54.3 & 55.5 & 55.5 & 57.0 & 57.8 & 57.5 & 59.4 & 23.9 & 0.3 & 460.7 & $1,238.2$ \\
\hline of which principal & 29.8 & 14.0 & 43.8 & 44.8 & 45.5 & 46.6 & 48.2 & 48.6 & 50.4 & 51.6 & 51.7 & 55.6 & 23.3 & 0.3 & 401.4 & $1,136.1$ \\
\hline of which interest & 6.1 & 2.5 & 8.7 & 8.3 & 8.0 & 7.7 & 7.3 & 6.9 & 6.6 & 6.2 & 5.8 & 3.8 & 0.7 & 0.0 & 59.3 & 102.2 \\
\hline Debt service after HIPC assistance ${ }^{2}$ & 35.9 & 6.0 & 41.9 & 22.8 & 23.1 & 23.6 & 24.3 & 24.4 & 25.0 & 26.0 & 26.0 & 59.4 & 23.9 & 0.3 & 201.2 & 978.7 \\
\hline of which principal & 29.8 & 5.0 & 34.7 & 18.5 & 18.9 & 19.6 & 20.5 & 20.8 & 21.5 & 22.6 & 22.8 & 55.6 & 23.3 & 0.3 & 170.2 & 904.8 \\
\hline of which interest & 6.1 & 1.0 & 7.2 & 4.3 & 4.1 & 4.0 & 3.8 & 3.7 & 3.5 & 3.4 & 3.2 & 3.8 & 0.7 & 0.0 & 31.0 & 73.9 \\
\hline Savings on debt service to IDA & 0.0 & 10.5 & 10.5 & 30.4 & 30.4 & 30.7 & 31.2 & 31.1 & 31.9 & 31.8 & 31.6 & 0.0 & 0.0 & 0.0 & 259.5 & 259.5 \\
\hline of which principal & 0.0 & 9.0 & 9.0 & 26.3 & 26.5 & 27.0 & 27.7 & 27.8 & 28.9 & 28.9 & 28.9 & 0.0 & 0.0 & 0.0 & 231.2 & 231.2 \\
\hline of which interest & 0.0 & 1.5 & 1.5 & 4.1 & 3.9 & 3.7 & 3.5 & 3.3 & 3.0 & 2.8 & 2.6 & 0.0 & 0.0 & 0.0 & 28.3 & 28.3 \\
\hline \multicolumn{17}{|l|}{ II. Relief under the MDRI ${ }^{3}$} \\
\hline Projected stock of IDA credits outstanding at implementation date ${ }^{4}$ & & $1,136.1$ & & & & & & & & & & & & & & \\
\hline Remaining IDA credits after MDRI & & 143.6 & & & & & & & & & & & & & & \\
\hline Debt stock reduction on eligible credits & & 992.5 & & & & & & & & & & & & & & \\
\hline Due to HIPC relief & & 231.2 & & & & & & & & & & & & & & \\
\hline Due to MDRI & & 761.2 & & & & & & & & & & & & & & \\
\hline Debt service due after HIPC relief and the MDRI & 35.9 & 0.3 & 36.2 & 3.5 & 3.6 & 3.9 & 4.0 & 4.0 & 4.0 & 4.3 & 4.3 & 6.5 & 6.2 & 0.3 & 31.8 & 161.8 \\
\hline \multicolumn{17}{|l|}{ Memorandum item: } \\
\hline Debt service to IDA covered by HIPC assistance (in percent) & 0.0 & 63.6 & 20.1 & 57.2 & 56.9 & 56.6 & 56.2 & 56.0 & 56.1 & 55.0 & 54.9 & 0.0 & 0.0 & 0.0 & 56.3 & 21.0 \\
\hline Debt service to IDA covered by HIPC assistance and MDRI (in percent) & 0.0 & 98.1 & 31.0 & 93.4 & 93.2 & 92.9 & 92.9 & 92.8 & 93.0 & 92.5 & 92.5 & 89.0 & 74.1 & 0.0 & 93.1 & 86.9 \\
\hline IDA debt service relief under the MDRI (in SDR) ${ }^{6}$ & 0.0 & 3.5 & 3.5 & 11.9 & 12.1 & 12.2 & 12.6 & 12.7 & 13.0 & 13.4 & 13.4 & 32.8 & 10.9 & 0.0 & 104.9 & 505.5 \\
\hline IDA debt service relief due to HIPC assistance at Decision Point exchange rate (in USD) $)^{7}$ & 0.0 & 9.4 & 9.4 & 27.3 & 27.3 & 27.6 & 28.0 & 27.9 & 28.7 & 28.6 & 28.4 & 0.0 & 0.0 & 0.0 & 233.3 & 233.3 \\
\hline
\end{tabular}

Source: IDAstaff estimates.

${ }^{1}$ Principal and interest due to IDA correspond to prorated projections on disbursed and outstanding debt as of end-December 2011, converted to U.S. dollar at end-2011 exchange rates.

${ }^{2}$ Principal and interest due to IDA correspond to prorated projections on disbursed and outstanding debt as of end-December 2011 minus HIPC interim and post-CP debt service reduction disbursed and outstanding debt as of end-December 1999

${ }^{3}$ Stock of debt and debt service denominated in SDRs are converted into U S. dollar by applying the end-2011 exchange rate.

${ }^{4}$ Stock of debt outstanding on October 1,2012

${ }^{5}$ Debt disbursed as of December 31, 2003 and still outstanding at September $30,2012$.

${ }^{6}$ For SDR denominated credits, debt relief under the MDRl is estimated as debt service on SDR denominated credits minus USD-based HIPC debt relief on these credits. HIPC debt relief is converted into SDR equivalent

amounts, from July 2012 onwards, by applying the provisional IDA16 foreign exchange reference rate of 1.48899 U.S. dollars per SDR. For USD denominated credits, debt relief under the MDRI is estimated as debt service on USD

denominated credits minus USD-based HIPC debt relief on these credits. The resulting MDRI debt relief amounts are converted into SDR equivalent amounts by applying the IDA16 foreign exchange reference rate.

${ }^{7}$ Actual amount of debt service reduction due to HIPC assistance. Converted to U.S. dollar at end-1999 exchange rate. 
Table A10. Guinea: Possible Delivery of IMF Assistance Under the Enhanced HIPC Initiative and the MDRI, 2000-22 1/ (In millions of SDRs, unless otherwise indicated)

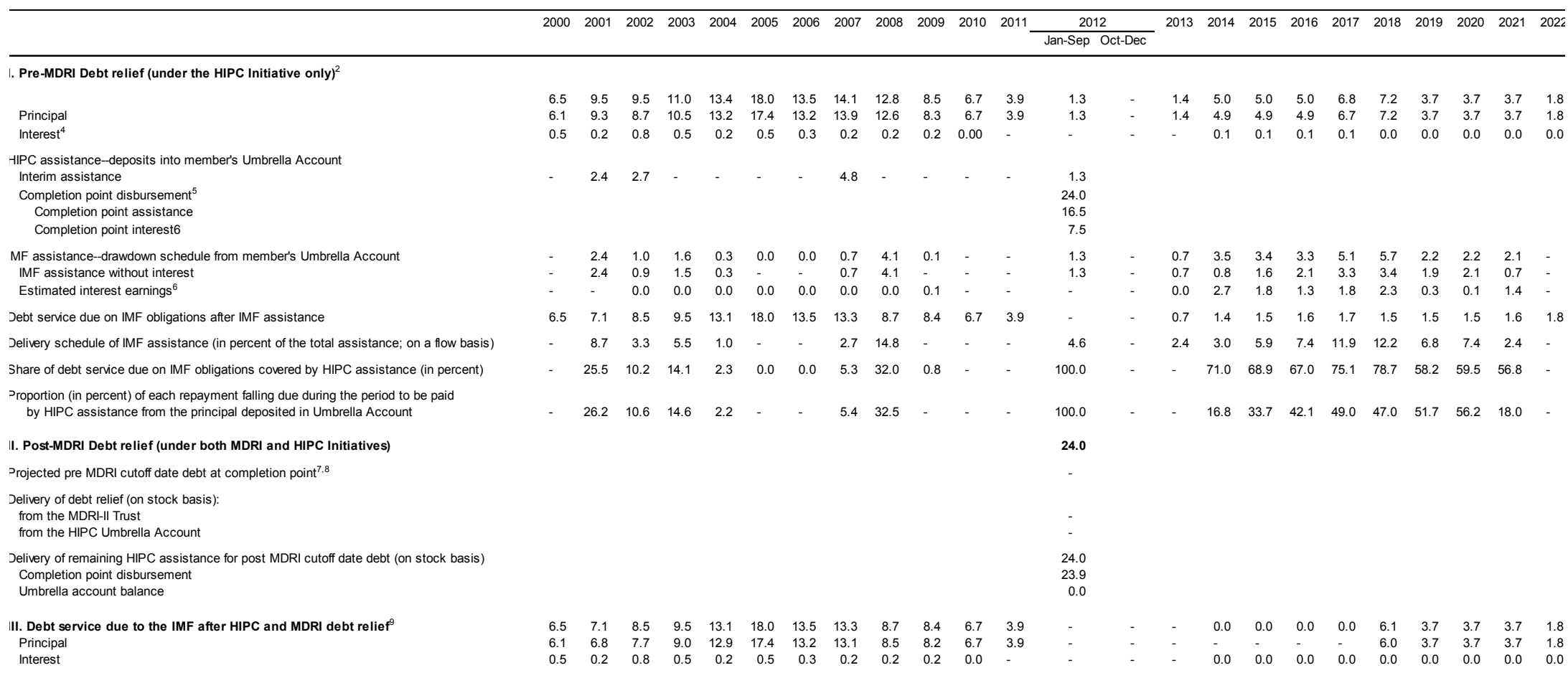

Source: Fund staffestimates and projections.

' Total IMF assistance under the enhanced HIPC Initiative amounts to SDR 27.8 million (equivalent to US $\$ 36$ million using exchange rate on 12/20/2000) in end-December 1999 PV terms, somewhat higher than the amount calculated at the decision point (SDR 24.24 million or US $\$ 31.40$ million) owing to debt revisions. This amount excludes interest earned in Guinea's Umbrella account and on committed
but undisbursed amounts as described in footnote 6 . Completion point (CP) is assumed on September 27,2012 .

'Estimated delivery of HIPC assistance in the absence ormPRI pocision

'Data are actual through end-July 2012. Forthcoming obligations after July 2012 are based on schedules in effect as of end-July 2012. Interest obligations exclude net SDR charges and assessments.

'On December 1, 2011 the IMF Board extended through December 31, 2012, the waiver of interest payments for concessional loans that was introduced on January7, 2010. For 2013, interest rates will be zero percent for ECF and RCF loans, and 0.25 percent per annum for the SCF and ESF loan After 2013, projected interest charges are based on 0.25 percent per annum. The Fund will review the interest rates for all PRGT facilities by end-2013 and every two years thereafter.

'A final amount of SDR 16.5 million will be deposited into Guinea's Umbrella Account at CP expected in end-September 2012.

'Includes estimated interest earnings on: (a) amounts held in Guinea's Umbrella Account, and (b) up to CP, amounts committed but not yet disbursed. The projected interest earnings are estimated based on assumed interest rates which are gradually rising to 4.5 percent in 2017 and beyon

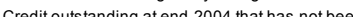

(1) 
Table A11. Guinea: Status of Creditor Participation Under the Enhanced HIPC Initiative 1/

\begin{tabular}{|c|c|c|c|c|}
\hline & $\begin{array}{l}\text { Debt Relief in } \\
\text { NPV Terms } \\
\text { (US\$ million) }\end{array}$ & $\begin{array}{l}\text { Percentage } \\
\text { of Total } \\
\text { Assistance }\end{array}$ & $\begin{array}{l}\text { Satisfactory } \\
\text { Reply to } \\
\text { Participate in } \\
\text { Initiative }\end{array}$ & Modalities to Deliver Debt Relief \\
\hline African Development Bank Group & 94.4 & 14.8 & Yes & $\begin{array}{l}\text { Interim relief provided in } 2000-03 \text { and } 2008 \text { amounts to USD } 37.6 \text { million in end- } \\
1999 \text { PV terms. At completion point, the AfDB Group is assumed to provide the } \\
\text { remaining amount of relief through additional reduction of debt service on debt } \\
\text { outstanding at end-December } 1999 \text { until full relief has been given. }\end{array}$ \\
\hline BADEA & 10.4 & 1.6 & Yes & $\begin{array}{l}\text { In } 2004 \text { and 2008, BADEA rescheduled accrued arrears falling due in } 2005 \text { and } \\
2006 \text { and in } 2008 \text {, respectively, which represented relief of USD } 2.0 \text { million in } \\
\text { end-1999 PV terms. At completion point, additional relief will be provided } \\
\text { through a concessional rescheduling of debt. }\end{array}$ \\
\hline $\begin{array}{l}\text { ECOWAS Bank for Investment and } \\
\text { Development }\end{array}$ & 1.7 & 0.3 & No & Not currently participating. \\
\hline European Investment Bank & 4.3 & 0.7 & Yes & $\begin{array}{l}\text { Interim relief amounting to USD } 1.5 \text { million in end-1999 PV terms provided } \\
\text { through the cancellation of debt service on selected EIB loans. No outstanding } \\
\text { EIB loans remain at completion point. Remaining HIPC relief will be provided on } \\
\text { EU loans. }\end{array}$ \\
\hline $\begin{array}{l}\text { European Union (administered by } \\
\text { EIB) }\end{array}$ & 32.0 & 5.0 & Yes & $\begin{array}{l}\text { Interim relief amounting to USD } 12.0 \text { million in end-1999 PV terms provided by } \\
\text { the EU through the cancellation of debt service and arrears on selected loans. } \\
\text { At completion point, the EU will provide the remaining relief by providing debt } \\
\text { service reduction on selected outstanding loans. }\end{array}$ \\
\hline World Bank & 173.6 & 27.2 & Yes & $\begin{array}{l}\text { Interim relief provided from } 2001 \text { to } 2008 \text { amounts to USD } 75.8 \text { million in end- } \\
1999 \text { PV terms. At completion point, IDA is assumed to provide the remaining } \\
\text { amount of relief through a } 68.5 \text { percent reduction of Guinea's debt service to } \\
\text { IDA through December } 2020 \text {. }\end{array}$ \\
\hline IFAD & 8.0 & 1.3 & Yes & $\begin{array}{l}\text { No interim relief provided. At completion point IFAD will provide up to } 100 \\
\text { percent debt service relief until PV target is achieved. }\end{array}$ \\
\hline IMF & 36.0 & 5.6 & Yes & $\begin{array}{l}\text { Interim relief provided amounts to USD } 14.6 \text { million in nominal. At completion } \\
\text { point, the IMF is assumed to provide the remaining amount of relief by (partially) } \\
\text { cancelling principal payments until } 2018 \text {. }\end{array}$ \\
\hline Islamic Development Bank & 18.7 & 2.9 & Yes & $\begin{array}{l}\text { In } 2005 \text { the IsDB rescheduled accrued arrears and payments falling due through } \\
\text { December } 2006 \text {, while it provided a three-year moratorium on payments on } \\
\text { selected loans from } 2008-10 \text {. This represented debt relief of USD } 3.9 \text { million in } \\
\text { end-1999 PV terms. At completion point, additional relief will be provided } \\
\text { through a concessional rescheduling of debt. }\end{array}$ \\
\hline $\begin{array}{l}\text { OPEC Fund for International } \\
\text { Development (OFID) }\end{array}$ & 4.1 & 0.6 & Yes & $\begin{array}{l}\text { In } 2002 \text {, OFID disbursed a concessional loan to refinance USD } 9.0 \text { million of } \\
\text { existing loans, which delivered USD } 3.0 \text { million in end-1999 PV terms of interim } \\
\text { relief. At completion point, additional relief will be provided through a } \\
\text { concessional rescheduling of debt. }\end{array}$ \\
\hline Total multilateral & 383.0 & 60 & & \\
\hline Non-Paris Club creditors & 65.3 & 10 & Some & $\begin{array}{l}\text { The Guinean authorities have already sent letters to their non-Paris Club } \\
\text { creditors requesting debt relief on Paris Club comparable terms. }\end{array}$ \\
\hline Bulgaria & 1.2 & 0.2 & No & Being contacted by the Guinean authorities. \\
\hline China & 9.8 & 1.5 & Yes & $\begin{array}{l}\text { The People's Republic of China has provided debt relief by canceling all } \\
\text { outstanding claims due before December } 31,2005 \text {. }\end{array}$ \\
\hline Egypt & 2.9 & 0.4 & Yes & Egypt has provided debt relief by canceling all their outstanding debt as of 2008 . \\
\hline Iraq & 0.7 & 0.1 & No & Iraq has agreed in principle to negotiate possible debt relief. \\
\hline Korea, DPR & 0.1 & 0.0 & No & North Korea has agreed in principle to negotiate possible debt relief. \\
\hline Kuwait & 17.6 & 2.8 & Yes & $\begin{array}{l}\text { Kuwait has provided its share of relief in } 2009 \text { by rescheduling outstanding } \\
\text { claims up to September } 1,2009 \text {. }\end{array}$ \\
\hline Libya & 4.3 & 0.7 & No & $\begin{array}{l}\text { Libya signed a rescheduling agreement with Guinea in } 2007 \text {, however the } \\
\text { agreement is deemed not effective as Guinea has not made debt service } \\
\text { payment in accordance to the agreement. }\end{array}$ \\
\hline Morocco & 2.9 & 0.5 & No & $\begin{array}{l}\text { Morocco has verbally agreed to provide debt relief through canceling all their } \\
\text { end-99 claims. However no written confirmation has been received by the } \\
\text { Guinean authorities yet. }\end{array}$ \\
\hline Romania & 1.8 & 0.3 & Yes & $\begin{array}{l}\text { Romania has already provided its proportionate share of HIPC assistance in } \\
2006 \text { by a stock of debt cancellation. }\end{array}$ \\
\hline Saudi Arabia & 21.9 & 3.4 & Yes & $\begin{array}{l}\text { Saudi Arabia has provided its share of relief in } 2009 \text { by rescheduling } \\
\text { outstanding claims up to September } 30,2009 .\end{array}$ \\
\hline Thailand & 0.5 & 0.1 & No & Being contacted by the Guinean authorities. \\
\hline Yugoslavia & 1.6 & 0.3 & No & Being contacted by the Guinean authorities. \\
\hline Commercial creditors & 2.8 & 0.4 & No & \\
\hline Total bilateral and commercial & 256.1 & 40 & & \\
\hline Total & 639.2 & 100 & & \\
\hline
\end{tabular}

Sources: Guinean authorities, and World Bank and IMF staff estimates.

${ }^{1}$ Based on the latest data available at the completion point after full application of traditional debt relief mechanisms. 
Table A12. Guinea: Paris Club Creditors' Delivery of Debt Relief Under Bilateral
Initiatives beyond the HIPC Initiative 1/

\begin{tabular}{|c|c|c|c|c|c|c|c|c|}
\hline \multirow[t]{3}{*}{ Countries Covered } & \multirow[b]{3}{*}{ (1) } & \multicolumn{2}{|c|}{ ODA (In percent) } & \multicolumn{3}{|c|}{ Non-ODA (In percent) } & \multicolumn{2}{|c|}{ Provision of Relief } \\
\hline & & $\begin{array}{l}\text { Pre-cutoff } \\
\text { Date Debt }\end{array}$ & \multirow{2}{*}{$\begin{array}{r}\text { Post-cutoff } \\
\text { Date Debt } \\
\\
(3) \\
\end{array}$} & \multirow{2}{*}{$\begin{array}{r}\text { Pre-cutoff } \\
\text { Date Debt } \\
\\
\text { (4) } \\
\end{array}$} & \multirow{2}{*}{\multicolumn{2}{|c|}{$\begin{array}{l}\text { Post-cutoff } \\
\text { Date Debt } \\
\\
\text { (5) }\end{array}$}} & \multirow{2}{*}{$\begin{array}{l}\text { Decision Point } \\
\text { (In percent) } \\
\text { (6) }\end{array}$} & \multirow{2}{*}{$\begin{array}{r}\text { Completion Point } \\
\text { (7) }\end{array}$} \\
\hline & & (2) & & & & & & \\
\hline Australia & HIPCs & 100 & 100 & 100 & & $100^{2}$ & 2 & 2 \\
\hline Austria & HIPCs & 100 & - & 100 & & $-\mathrm{C}$ & se-by-case, flow & Stock \\
\hline Belgium & HIPCs & 100 & $100^{3}$ & 100 & & - & 100 flow & Stock \\
\hline Canada & HIPCs & 100 & 100 & 100 & & 100 & 100 flow & Stock \\
\hline Denmark & HIPCs & 100 & $100^{4}$ & 100 & & $100^{4}$ & 100 flow & Stock \\
\hline France & HIPCs & 100 & 100 & 100 & & - & 100 flow $^{5}$ & Stock \\
\hline Finland & HIPCs & 100 & -6 & 100 & & -6 & - & - \\
\hline Germany & HIPCs & 100 & 100 & 100 & & $100^{7}$ & 100 flow & Stock \\
\hline Ireland & - & - & - & - & & - & - & - \\
\hline Italy & HIPCs & 100 & $100^{8}$ & 100 & & $100^{8}$ & 100 flow & Stock \\
\hline Japan & HIPCs & 100 & 100 & 100 & & - & - & Stock \\
\hline Netherlands, the & HIPCs & $100^{9}$ & 100 & 100 & & - & $90-100$ flow $^{9}$ & Stock \\
\hline Norway & HIPCs & 10 & 10 & 11 & & 11 & - & - \\
\hline Russia & HIPCS & -12 & -12 & 100 & & 100 & - & Stock \\
\hline Spain & HIPCs & 100 & $100^{13}$ & 100 & & $100^{13}$ & - & Stock \\
\hline Sweden & HIPCs & - & -14 & 100 & & - & - & Stock \\
\hline Switzerland & HIPCs & -15 & -15 & 100 & 16 & - & 100 flow $^{16}$ & Stock \\
\hline United Kingdom & HIPCs & 100 & 100 & 100 & & $100^{17}$ & 100 flow $^{17}$ & Stock \\
\hline United States ${ }^{18}$ & HIPCs & 100 & 100 & 100 & & 100 & 100 flow & Stock \\
\hline
\end{tabular}

Source: Paris Club Secretariat.

${ }^{1}$ Columns (1) to (7) describe the additional debt relief provided following a specific methodology under bilateral initiatives and need to be read as a whole for each creditor In column (1), "HIPCs" stands for eligible countries effectively qualifying for the HIPC process. A "100 percent" mention in the table indicates that the debt relief provided under the enhanced HIPC Initiative framework will be topped up to 100 percent through a bilateral initiative.

${ }^{2}$ Australia: Australia cancelled all HIPC claims.

${ }^{3}$ Belgium: cancellation at completion point 100 percent of ODA loans contracted before December 31, 2000.

${ }^{4}$ Denmark provides 100 percent cancellation of ODA loans and non-ODA credits contracted and disbursed before September 27, 1999.

${ }^{5}$ France: cancellation of 100 percent of debt service on pre-cutoff date commercial claims on the government as they fall due starting at decision point. Once

countries have reached completion point, debt relief on ODA claims on the government will go to a special account and will be used for specific development projects.

${ }^{6}$ Finland: no post-Cutoff date claims

${ }^{7}$ If not treated in the Agreed Minutes at Completion Point, debt cancellation of $100 \%$ only on a case by case basis.

${ }^{8}$ Italy: cancellation of 100 percent of all debts (pre- and post-cutoff date, ODA and non-ODA) incurred before June 20,1999 (the Cologne Summit).

At decision point, cancellation of accrued arrears and maturities falling due in the interim period. At completion point, cancellation of the stock of remaining debt.

${ }^{9}$ The Netherlands: 100 percent ODA (pre- and post-cutoff date debt will be cancelled at decision point); for non-ODA: in some particular cases (Benin, Bolivia,

Burkina Faso, Ethiopia, Ghana, Mali, Mozambique, Nicaragua, Rwanda, Tanzania, Uganda and Zambia), the Netherlands will write off 100 percent of the consolidated amounts on the flow at decision point; all other HIPCs will receive interim relief up to 90 percent reduction of the consolidated amounts. At completion point, all HIPCs will receive 100 per cent cancellation of the remaining stock of the pre-cutoff date debt.

${ }^{10}$ Norway has cancelled all ODA claims.

${ }^{11}$ Due to the current World Bank/IMF methodology for recalculating debt reduction needs at HIPC completion point, Norway has postponed the decisions on whether or

not to grant $100 \%$ debt reduction until after HIPCs' completion point.

${ }^{12}$ Russia has no ODA claims

${ }^{3}$ Spain provides 100 percent cancellation of ODA and non-ODA claims contracted before January 1, 2004

${ }^{14}$ Sweden has no ODA claims.

${ }^{15}$ Switzerland has cancelled all ODA claims.

${ }^{6}$ Switzerland usually writes off 100 percent of government-owned claims of the remaining debt stock at Completion Point and provides at least full HIPC debt relief

of claims held by the ECA ( $100 \%$ cancellation of all remaining claims with the exception of Honduras and Cameroon).

${ }^{17}$ United Kingdom: "beyond 100 percent" full write-off of all debts of HIPCs as of their decision points, and reimbursement at decision point of any debt service

paid before the decision point.

${ }^{18}$ United States: cancellation of 100 percent of all debts (pre- and post-cutoff date, ODA and non-ODA) incurred before June 20, 1999 (the Cologne Summit) At decision point, cancellation of accrued arrears and maturities falling due in the interim period. At completion point, cancellation of the stock of remaining eligible debt. 
Table A13. Guinea: HIPC Initiative - Status of Country Cases Considered Under the Initiative, June 30, 2012

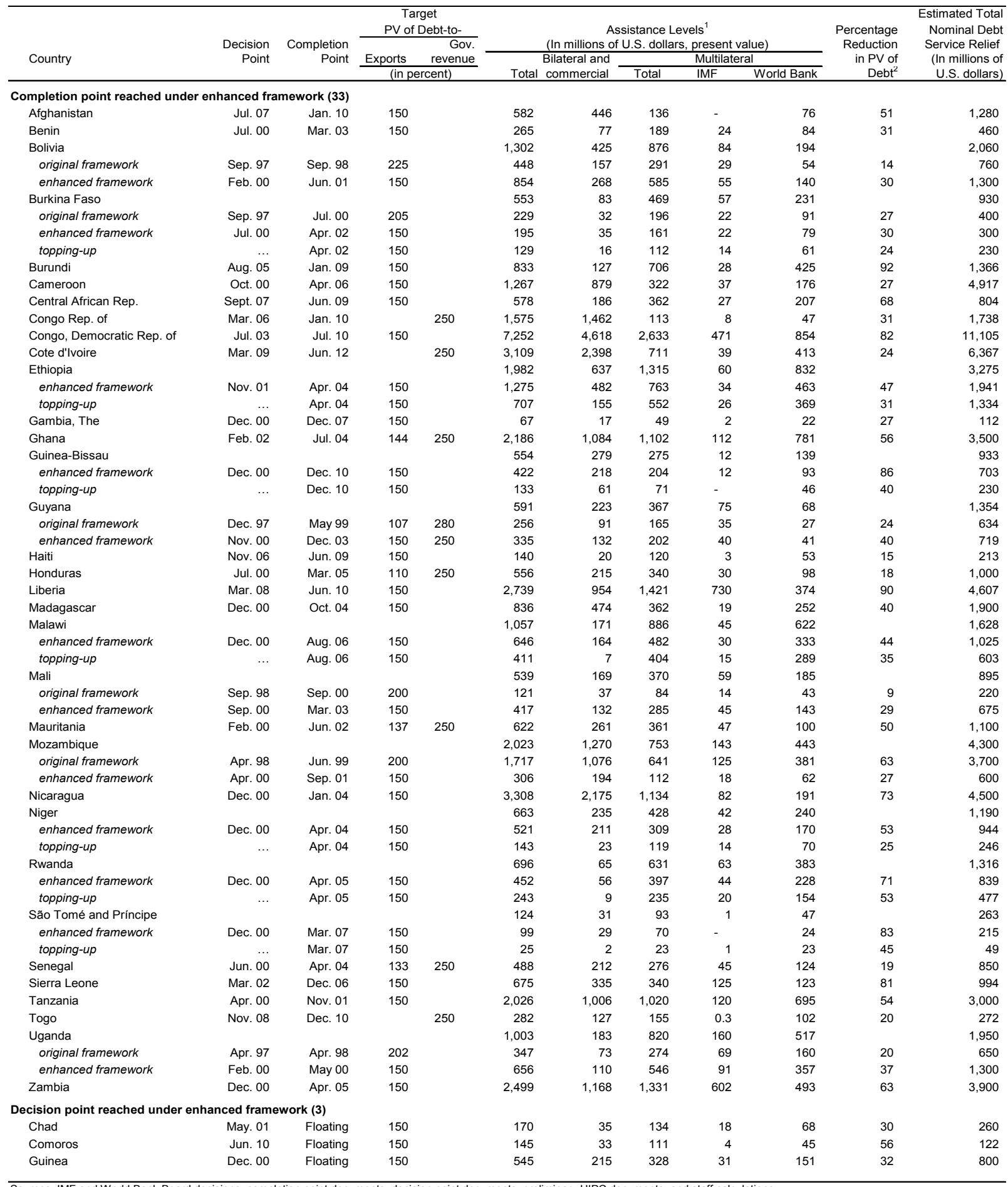

1 Assistance levels are at countries' respective Decision or Completion Points, as applicable.

2 In percent of the present value of debt at the Decision or Completion Point (as applicable), after the full use of traditional debt-relief mechanisms. 


\section{APPENDIX I-Guinea: DEBT MANAGEMENT ${ }^{1}$}

1. Guinea's legal and institutional framework clearly defines who has authority to borrow and the responsibilities in negotiating new loans and making payments.

According to the charter budget law (2008), only the Minister of Economy and Finance has the authority to borrow from legal entities, exclusively for the purposes defined in the law itself and for the amounts and modalities established in the annual budget law. According to a recent decree, the National Debt and Public Development Aid Directorate (DND) ${ }^{2}$ will participate in searching for new financing and in negotiations for new loans (front office functions), and will be responsible for elaborating a debt management strategy (middle office). The DND is also responsible for managing, recording, and reporting on domestic and external debt and debt-related transactions and domestic debt, including securitized liabilities to the Central Bank of the Republic of Guinea (BCRG) and domestic suppliers (back office). The BCRG acts as the agent of the Ministry of Economy and Finance (MEF) for managing the domestic Treasury-bill market and is responsible for making external debt payments as instructed by the DND.

2. However, borrowing is currently not based on a medium-term debt management strategy. At present, the only explicit external debt management goal is to contract external borrowing only on concessional terms with a minimum grant element of 35 percent as indicated in the ECF-supported program, which the DND checks during new loan negotiations.

3. The debt data recording capacity remains weak and not centralized. Formally, the DND uses the CS-DRMS 2000+ debt recording and management system, which is hosted off-site by the National Information Systems Directorate. In practice, staff for external debt works mainly on the basis of locally hosted spreadsheets, because access to CS-DRMS is difficult due to frequent power cuts and other technical issues. These spreadsheets mainly cover monthly debt service payment forecasts, and are validated against creditor statements. Every year a data call is sent out to all creditors to provide debt service payment projections for the next fiscal year, which is then integrated into the budget. The lack of timely and systematic information on new disbursements and sometimes on new loans ${ }^{3}$ further complicates debt recording. Staffs were able to show debt records and contracts upon request, but a decent filing system seems to be lacking.

\section{The DND publishes quarterly bulletins and has published an annual activity}

report. The DND regularly reports the principal debt indicators to the Minister of Finance in an internal report and to external partners, and produces annual activity reports. The Treasurer reports regularly on the outstanding stock of Treasury-bills. External or internal debt audits are conducted on domestic debt but not on external debt, although the authorities acknowledge the need for it.

\footnotetext{
${ }^{1}$ Guinea received a World Bank Debt Management Performance Assessment (DeMPA) in 2008.

${ }^{2}$ See Arrêté No//MEF/CAB/2011 portant attributions et organisation de la Direction nationale de la dette et de l'aide publique au développement.

${ }^{3}$ In practice, there have been cases where another minister has signed loan contracts with a bilateral creditor.
} 


\section{Staff seems to be unevenly distributed, and although staff capacity seems} adequate for basic debt management functions, more training is needed. Although the DND has 66 staff, the bilateral debt unit had about four staff, while the multilateral debt unit at the time of the completion point only had one staff, even though the recently adopted organizational chart has assigned three staff for each unit. Staff generally have university degrees and has been trained in the use of the debt management software, and regularly attend training events organized by the Commonwealth Secretariat. Some staff were also trained on debt sustainability analysis and other debt management activities (e.g., DeMPA, creating a procedures manual for debt management) at regional training events organized by the World Bank, IMF West AFRITAC, the AfDB, and Pôle-Dette, recently in March 2012 in Mali, and June 2012 in Senegal.

6. Debt management needs to be strengthened. Notwithstanding the formal and legal centralized authority of the Minister of Finance to approve any external borrowing (see above), two lapses occurred in 2011 when a newly created entity (SOGUIPAMI) responsible for managing the government's assets in the mining sector was the cause for the contracting of two external loans. To avoid a recurrence, the government is undertaking a study with World Bank assistance of the appropriate institutional structure to manage the government's mining sector assets and related large infrastructure projects, and in the meantime has strictly curtailed SOGUIPAMI's independence and operations. In particular it cannot contract any external loans or other liabilities.

7. The completion point provides a good opportunity to improve debt management. HIPC and MDRI debt relief at the completion point will significantly reduce the stock of external debt and provides a clean slate for the country. At the same time, a reduced debt burden may eventually lead to a gradual easing of the limits placed on less concessional financing. It is therefore recommended that Guinea take steps to improve debt management in order to be prepared for this new era. In the area of governance, better information sharing (for example on new disbursements) is needed with the DND. A debt management strategy approved by the Minister of Finance could provide clear guidance to the DNIP for borrowing, such that the cost and financial risks are minimized. Debt management activities should be audited and recommendations for improvement should be followed.

Complementary to strengthening debt management, the government should pay attention to building its capacity to evaluate PPPs to ensure they do not entail contingent liabilities to the government. Staff could be used more efficiently. Investment in hardware is needed to make sure that CS-DRMS is used in real time, and becomes the unique database for external and domestic debt. Moreover, filing system of contracts, agreements and invoices could be enhanced to improve efficiency. The authorities should continue to produce annual activity reports and debt reports. 


\section{APPENDIX II-GUINEA: JOINT BANK-Fund DEBT SUSTAINABILITY ANALYSIS UNDER THE DEbT SUSTAINABILITY FraMEWORK FOR LOW-INCOME COUNTRIES ${ }^{1}$}

The debt sustainability analysis (LIC-DSA) shows that Guinea is at a moderate risk of debt distress. After full HIPC, MDRI and beyond-HIPC debt relief, all external indicators remain under their indicative thresholds throughout the projection period. However, the country remains vulnerable to certain macroeconomic shocks, especially during the first half of the projection period. The public sector debt sustainability analysis (DSA) indicates that Guinea's domestic debt is significant but is expected to decrease over the longer run and does not alter the assessment. The remaining vulnerability to macroeconomic shocks indicates the need for prudent fiscal policies and debt management.

\section{BACKGROUND}

1. This analysis (LIC-DSA) is based on the Debt Sustainability Framework (DSF) for Low-Income Countries. The DSA presents the projected path of Guinea's external and public sector debt indicators, and assesses the country's risk of external debt distress. The LIC-DSA and the HIPC Initiative Debt Relief Analysis (HIPC-DRA) share the same macroeconomic assumptions for the baseline, but methodologically, they differ. The LIC-DSA compares the evolution over the projection period of debt burden indicators against policy-dependent indicative thresholds. In contrast, under the HIPC-DRA, the historical debt burden indicators are compared to uniform thresholds in order to calculate the amount of HIPC debt relief that Guinea qualifies for in the context of the HIPC Initiative. In addition, the results of the LIC-DSA differ from the HIPC-DRA because of methodological differences related to the definition of the discount rates and the exchange rates used. ${ }^{2}$

2. This LIC-DSA ${ }^{3}$ updates the analysis of the external and public debt of Guinea that was considered by the Executive Board of the IMF in February 2012. ${ }^{4}$ At that time Guinea had been in debt distress since 2007, as evidenced by the accumulation of external debt service arrears.

\footnotetext{
${ }^{1}$ The DSA was prepared jointly by the staffs of the International Monetary Fund and the World Bank, in collaboration with the Authorities of Guinea. The fiscal year in Guinea is January 1 to December 31.

${ }^{2}$ The LIC-DSA and HIPC-DRA also differ because of the treatment of the French debt-for-development swaps (C2D).

${ }^{3}$ The DSAs presented in this document are based on the low-income countries (LIC) DSA framework. Under the Country Policy and Institutional Assessment (CPIA), Guinea is rated as a weak performer, with an average rating of 2.86 in 2008-10; the DSA uses the indicative threshold indicators for countries in this category. See "Debt Sustainability in Low-Income Countries: Proposal for an Operational Framework and Policy Implications" (http://www.imf.org/external/np/pdr/sustain/2004/020304.htm and IDA/SECM2004/0035, 2/3/04) and "Debt Sustainability in Low-Income Countries: Further Considerations on an Operational Framework, Policy Implications" http://www.imf.org/external/np/pdr/sustain/2004/091004.htm and IDA/SECM2004/0629, 9/10/04) and "A Review of Some Aspects of the Low-Income Country Debt Sustainability Framework" (http://www.imf.org/external/np/pp/eng/2009/080509a.pdf) and "Staff Guidance Note on the Application of the Joint Bank-Fund Debt Sustainability Framework for Low-Income Countries" (http://www.imf.org/external/np/pp/eng/2010/012210.pdf)

${ }^{4}$ See Supplement of IMF Country Report No. 12/63, March 2012, on LIC-DSA which can be found at: http://www.imf.org/external/pubs/ft/scr/2012/cr1263.pdf
} 


\section{At end-2011, Guinea's public and publicly guaranteed external debt was}

$\$ 3,194$ million, or 62 percent of 2011 GDP. ${ }^{5}$ The level of debt in nominal terms has been broadly stable in recent years, reflecting a low level of new loans and debt service paid, but with arrears accounting for a growing share (amounting to 12 percent of end-2011 debt outstanding). ${ }^{6}$ Multilateral creditors accounted for 62 percent of the total, with the AfDB group and IDA accounting for almost four-fifths of the multilaterals' share. Paris Club creditors accounted for 25 percent of total, while official bilateral non-Paris Club and commercial creditors made up the rest. $^{7}$

4. External debt service arrears reached $\$ 371$ million at end-2011. Paris Club creditors accounted for 60 percent of the total. During 2011, the government cleared its arrears with all multilateral creditors and resumed debt service payments in full to them. HIPC interim assistance was discontinued by a majority of creditors in 2009-10.

5. In April, 2012 the Paris Club and the Government of Guinea concluded a debt relief agreement on exceptional terms, including the rescheduling of post-cutoff date maturities and arrears. ${ }^{8}$ In addition, agreement was reached with European Union that outstanding arrears would in part be cancelled in 2011. Another part was frozen and will be cleared at the HIPC completion point using European Development Fund resources of the EU. As a result, outstanding arrears were reduced by about two-thirds; the remainder is to non-Paris Club official bilateral and commercial creditors on which no further debt service maturities fall due.

6. The level of public domestic debt reflects the considerable increase in 2009-10 of advances by the central bank to the government. During the military regime (2009-10), soaring expenditures were financed by borrowing from the domestic banking system. The liabilities of the government to the domestic banking system increased sharply from 13 percent of GDP in 2008, to 19 percent in 2009, and 30 percent in 2010. In 2011, large exceptional revenue from the mining sector (15 percent of GDP) was deposited at the central bank. The government has committed to refraining from any domestic bank financing of the budget other than stemming from the drawdown of this deposit. At end-June 2012, the stock of public domestic debt amounted to 11 percent of GDP, divided almost evenly between central bank advances and treasury bills held by domestic banks.

\footnotetext{
${ }^{5}$ Excluding arrears to the EU which, by agreement, have been frozen pending clearance at the HIPC completion point using European Development Fund resources of the EU.

${ }^{6}$ This share includes arrears to Paris Club creditors which were restructured under the April 2012 debt relief agreement. Excluding these arrears the share of arrears in end-2011 debt would be 7 percent.

${ }^{7}$ Guinea has no debt service obligations falling due to commercial creditors, and arrears account for the full amount of debt outstanding.

${ }^{8}$ The cut-off date is January $1,1986$.
} 
Guinea: Structure of External Public Debt (end-2011, nominal)

Text Table 1

\begin{tabular}{lrr}
\hline & US\$ million & Percent of GDP \\
\hline Total & 3,194 & 61.77 \\
Multilateral creditors & 1,966 & 38.02 \\
IMF & 42 & 0.80 \\
World Bank & 1,166 & 22.55 \\
AfDB Group & 393 & 7.60 \\
IsDB & 143 & 2.77 \\
EU & 59 & 1.14 \\
Other multilateral creditors & 163 & 3.15 \\
Official bilateral creditors & 1,142 & 22.10 \\
Paris Club & 813 & 15.73 \\
Non-Paris Club & 193 & 3.72 \\
Arab Funds & 137 & 2.65 \\
Commercial creditors & 85 & 1.65 \\
\hline Sources: Guinea authorities, and AfDB, World Bank, and IMF staff estimates
\end{tabular}

Text Figure 1

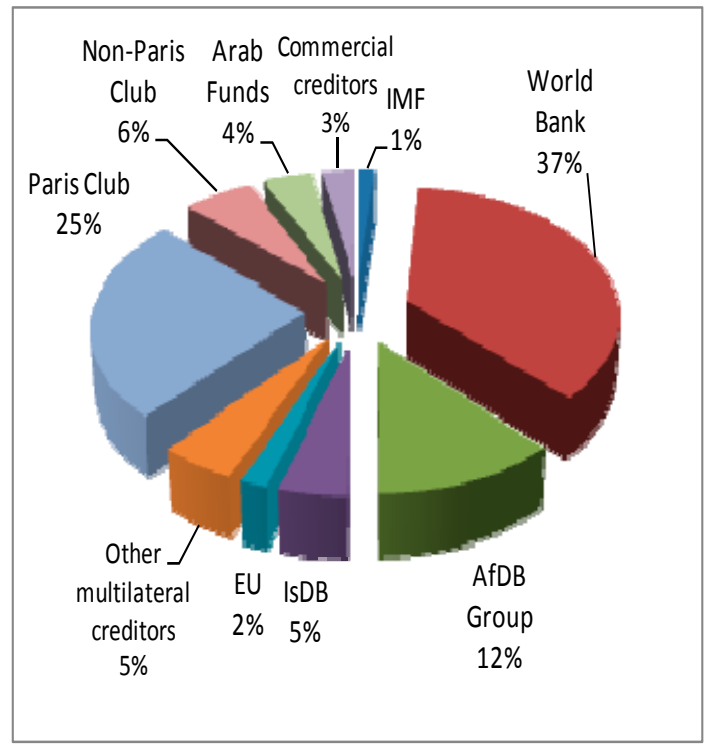

\section{BASELINE ASSUMPTIONS}

\section{The macroeconomic assumptions of the LIC-DSA are broadly consistent with} those used in the HIPC-DRA and those of the February 2012 LIC-DSA (Box 2 above). The baseline assumes a large increase in FDI which would underpin the start of large mining investments and a sizeable expansion in economic activity; political stability; sound macroeconomic management; prudent borrowing policies; and advancement in structural reforms over the medium term. It also assumes a substantial rise in public investment, especially in long-neglected infrastructure and the energy sector, as well as government support to develop agriculture and improve the business climate. These policies would provide a foundation for an increase in private investment, and would contribute to diversification of the economy and unlocking Guinea's long-run economic growth potential. Risks with regard to the macroeconomic projections include renewed political instability, especially in the run-up to parliamentary elections that were due in 2011 but that have been postponed several times, the potential further deterioration in the global economic outlook and mineral prices, and the possibility of projected mining production and revenues not materializing. With regard to external debt and financing needs, the DRA assumes all postcut-off date ODA debt to be cancelled as part of beyond HIPC bilateral debt relief, and the LIC-DSA assumes that such claims held by France of $€ 166$ million (about $\$ 210$ million) are to be converted into debt-for development-swaps (C2D) over 3 years.

8. The baseline scenario reflects the full delivery of HIPC completion point, MDRI and beyond-HIPC relief, as in the HIPC-DRA. The results below are broadly in line with the alternative scenario related to HIPC and MDRI relief in the February 2012 LIC-DSA, with a number of differences. The analysis discussed below incorporates the 
impact of beyond HIPC bilateral relief. Also, updated projections of debt service (based on the HIPC completion point data reconciliation) and updated calculations of the delivery of HIPC and MDRI relief were used. These revisions lead to lower post-completion point debt burden indicators. In addition, the LIC-DSA assumes that French post-cut-off date ODA claims are converted into debt-for-development swaps (C2D) over 2012-15, thereby increasing debt service in the short term. ${ }^{9}$ The initial fall in debt service relative to the 2012 LIC-DSA is dampened by the onset of the payments under C2D and the assumed restructuring of arrears to non-official bilateral and commercial creditors; under the 2012 Paris Club agreement payments to this group of creditors were already very low. Debt relief from multilateral financial institutions leads to a considerable reduction in debt service payments.

\section{EXTERnAl DEbT SuSTAINABILITY ANALYSIS}

\section{Under the baseline scenario, Guinea's external debt indicators remain below} their relevant indicative thresholds throughout the projection period (Table 1, Figure 1). Debt stock and debt service ratios would immediately fall and remain below their policy thresholds. The sharp drop reflects in particular the impact of HIPC and MDRI relief from multilaterals, especially the World Bank, which holds the largest share of Guinea's multilateral debt (almost 60 percent at end-2011). The PV of external debt-to-GDP and PV of external debt-to-exports ratios fall in 2012 and again in 2015, reflecting the end of C2D payments, and remain relatively stable over the projection period. The stability of the ratios despite a rise in public investment relative to GDP reflects the impact of the projected sizeable expansion in the mining sector after 2015. This expansion not only leads to significant increases in exports and GDP, but also in fiscal revenues. In turn, the increase in fiscal revenues reduces the need for public borrowing to finance higher public investment. Debt service ratios also remain below their indicative thresholds over the projection period; the impact of the end of C2D payments is accentuated for these debt service indicators.

\section{Alternative scenarios and stress tests show that the external debt burden indicators are vulnerable to adverse shocks (Figure 1):}

- If the main economic variables remain at their historical level, and policy improvements and the expected growth dividend assumed under the baseline do not materialize, the PV of debt-to-GDP ratio would rise above the policy threshold after 2022, and then begin to decline toward the end of the projection period. The PV of debt-to-revenue also deteriorates, but remains below the policy threshold, and then declines over the longer run; the PV of debt-to-exports ratio shows a similar deterioration but continues to rise throughout the projection period while remaining below the policy threshold. The indicators are also very sensitive to exogenous shocks.

\footnotetext{
${ }^{9}$ Under C2D (Contrats de désendettement et développement) the existing debt service maturities are consolidated and re-profiled, and when they are paid, they are returned to the country through grants from France into development spending.
} 
- Under most of the shocks considered in this analysis, the debt burden indicators would deteriorate; ${ }^{10}$ the shocks on exports and on non-debt creating flows (such as net foreign direct investment), and a combination shock are particularly important resulting in a significant worsening of the debt burden indicators. This reflects the fact that the improvement in macroeconomic prospects depends heavily on the projected large inflow of foreign direct investments in the mining sector and the related jump in mining exports.

\section{Guinea's external debt sustainability will be affected by the modalities of the} government's participation in large-scale infrastructure and mining projects. ${ }^{11}$ In the near-term this issue is raised in the context of the prospective SIMFER mining and infrastructure project. The total cost of the two projects is tentatively estimated at about \$17-18 billion (one-third mining and two-thirds for infrastructure), of which the government has options for a substantial participation. Full take up of these options would entail commensurately large financial contributions to the projects. Moreover this issue would be raised in possible similar future projects. While no decisions have yet been taken by the government on how much of its possible stake to take up or on the financing of its contribution, it has stated clearly that its participation will not involve direct borrowing or guarantees by the government. Instead it intends, for these projects and possible similar future projects, to rely on private-public partnerships through special purpose financing vehicles for which financing costs would be fully covered by project revenues, and involve no contingent liabilities to the government. The participation of the IFC in the SIMFER and possible participation of the World Bank in the infrastructure project should help ensure that the projects are designed to be viable.

\section{While the use of PPPs to finance the government's participation in large-scale} projects is a useful strategy to maintain external debt sustainability, given the magnitude of these projects it will be important that the government strengthen its capacity to ensure that any financing agreement does not include contingent liabilities, and second that projections of revenues are well-based and sufficient to cover financing costs of the PPP and thus avoid possible implicit contingent liabilities in situations where the collapse of a project could have widespread damaging economic and social impacts. The assumption of any liability, could lead to sharp deterioration in debt burden indicators, particularly on debt service ratios.

\section{Public Sector debt Sustainability}

\section{The inclusion of domestic debt in the debt sustainability analysis worsens the} debt burden indicators, although the domestic debt burden is expected to decrease over time (Table 3 and Figure 2). Following the large increase in borrowing from the domestic

\footnotetext{
${ }^{10}$ Simulations included shocks on GDP growth, export growth, inflation, non-debt creating flows, and exchange rate depreciation. The combination shock includes one-half standard deviation shocks to real GDP growth, exports, GDP deflator and net non-debt creating flows.

${ }^{11}$ See also discussion in the HIPC DRA.
} 
banking system in 2009-10, the authorities virtually eliminated new borrowing in 2011, and in 2012-13 there is no new domestic financing planned for the budget, while net repayments of domestic debt are expected to resume. ${ }^{12}$ As a result, the PV of public debt-to-GDP ratio would gradually decline from 29 percent of 2012 GDP to 9.8 percent of GDP at the end of the projection period. Debt service on total public debt would drop in 2012, and then again in 2015, and thereafter remain broadly stable reflecting largely the external debt service trend described above.

\section{The public debt position is vulnerable to shocks, particularly to policy reversals} (Table 4 and Figure 2). Under the fixed primary balance, historical average and the most extreme shock scenarios, the public debt burden indicators would be at least twice as high compared to the trajectories under the baseline scenario in the long term; in addition, the indicators show a rising trend over the projection period for the fixed primary balance scenario.

\section{In light of the results of the baseline and alternative scenarios as well as the} stress tests, IDA and IMF staffs conclude that Guinea is at a moderate risk of debt distress.

\section{Conclusions}

\section{This LIC-DSA shows that Guinea would be at a moderate risk of debt distress} after the HIPC completion point. This compares to the "in debt distress" assessment in the February 2012 LIC-DSA. Under the current baseline scenario, the HIPC Initiative, MDRI and beyond-HIPC relief significantly improve the external debt indicators over the projection period. All debt burden indicators remain below their policy-dependent thresholds throughout the projection period. Alternative scenarios and stress tests reveal the vulnerability of Guinea's external debt outlook, as the debt burden indicators rise and some breach the policy thresholds. The inclusion of domestic debt moderately weakens the debt outlook, but does not alter the assessment of Guinea's risk of debt distress.

\section{This LIC-DSA underscores the importance of sustained implementation of sound macroeconomic policies, improvements in the business environment, and} prudent debt management. Such policies are key to realizing the expected growth dividend, especially expansion of activity in the mining sector, and improved export and fiscal revenue performance, and with sound debt management are important for maintaining debt sustainability. In addition, the stress tests underscore the need for reducing the vulnerability of revenue and exports to commodity prices, in particular of metals, through output and export diversification. Debt relief under the HIPC Initiative, MDRI and beyond-HIPC assistance provides significant space for Guinea to access more concessional financing, increasing its ability to address its considerable public investment needs and improving growth prospects. However, in light of remaining vulnerabilities, large-scale new borrowing

\footnotetext{
${ }^{12}$ Under an agreement between the Ministry of Economy and Finance and the central bank, the government will repay its advances over a period of 40 years, starting in 2020.
} 
should be avoided and the authorities have emphasized their commitment to ensure that the government's participation in large-scale infrastructure projects and mining projects does not involve the use of budget resources to meet the associated financing needs; instead the government intends to make use of public-private partnerships (PPPs) in which project revenues are used to service debt committed under the project, thus avoiding significant government borrowing on nonconcessional terms. ${ }^{13}$ However, to ensure that PPP agreements do not entail contingent liabilities, the administrative capacity to evaluate such liabilities needs to be strengthened and a clear regulatory framework for such partnerships needs to be established.

18 The Guinean authorities broadly concurred with the assumptions and conclusions of the DSA.

${ }^{13}$ See Supplement of IMF Country Report No. 12/63, March 2012 on LIC-DSA for a fuller discussion of this issue. 
Figure 1. Guinea: Indicators of Public and Publicly Guaranteed External Debt under Alternatives Scenarios, 2012-2032 1/
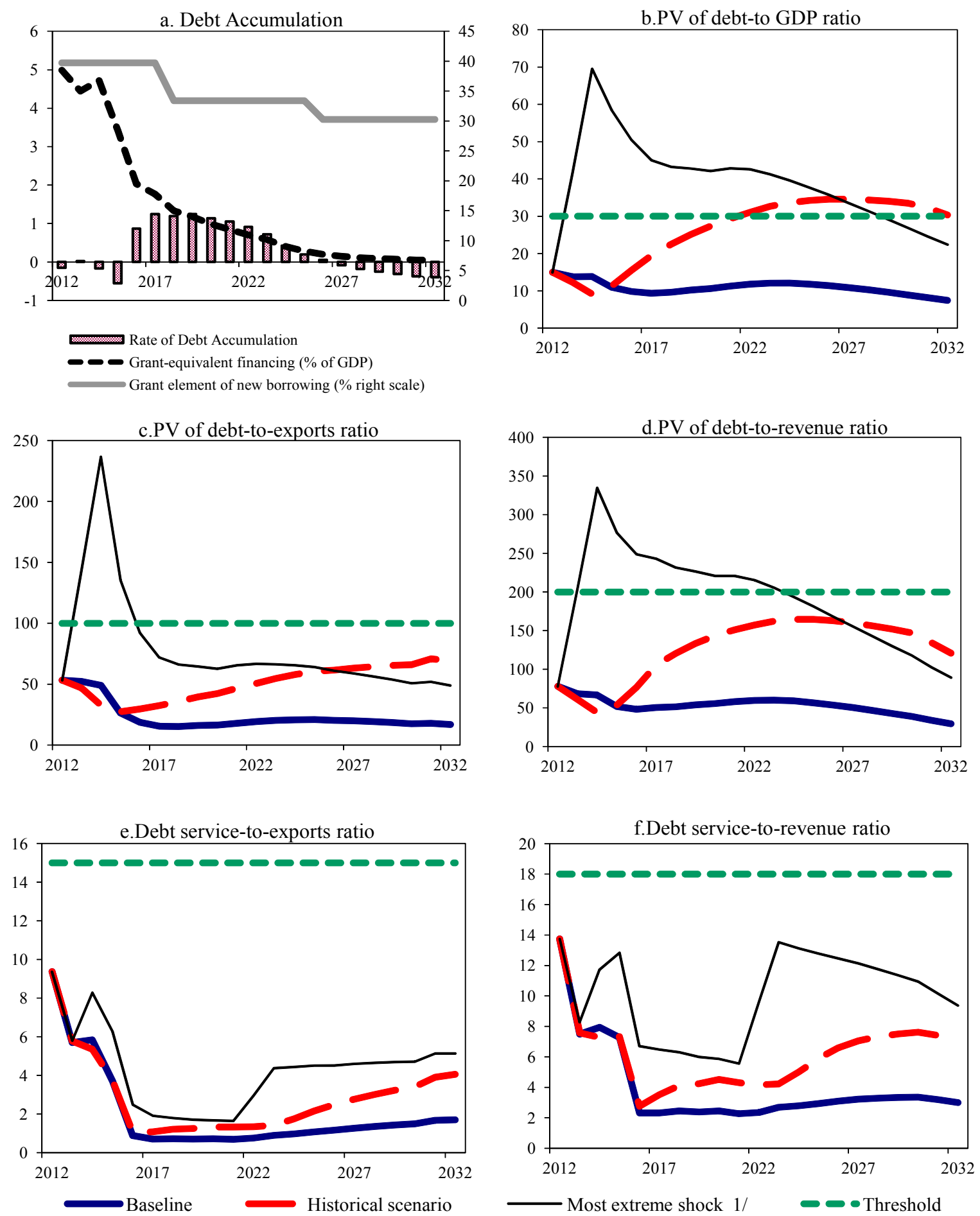

Sources: Country authorities; and staff estimates and projections.

$1 /$ The most extreme stress test is the test that yields the highest ratio in 2022. In figure b. it corresponds to a Combination shock; in c. to a Combination shock; in d. to a Combination shock; in e. to a Combination shock and in figure f. to a Combination shock 
Figure 2.Guinea: Indicators of Public Debt Under Alternative Scenarios, 2012-2032 1/
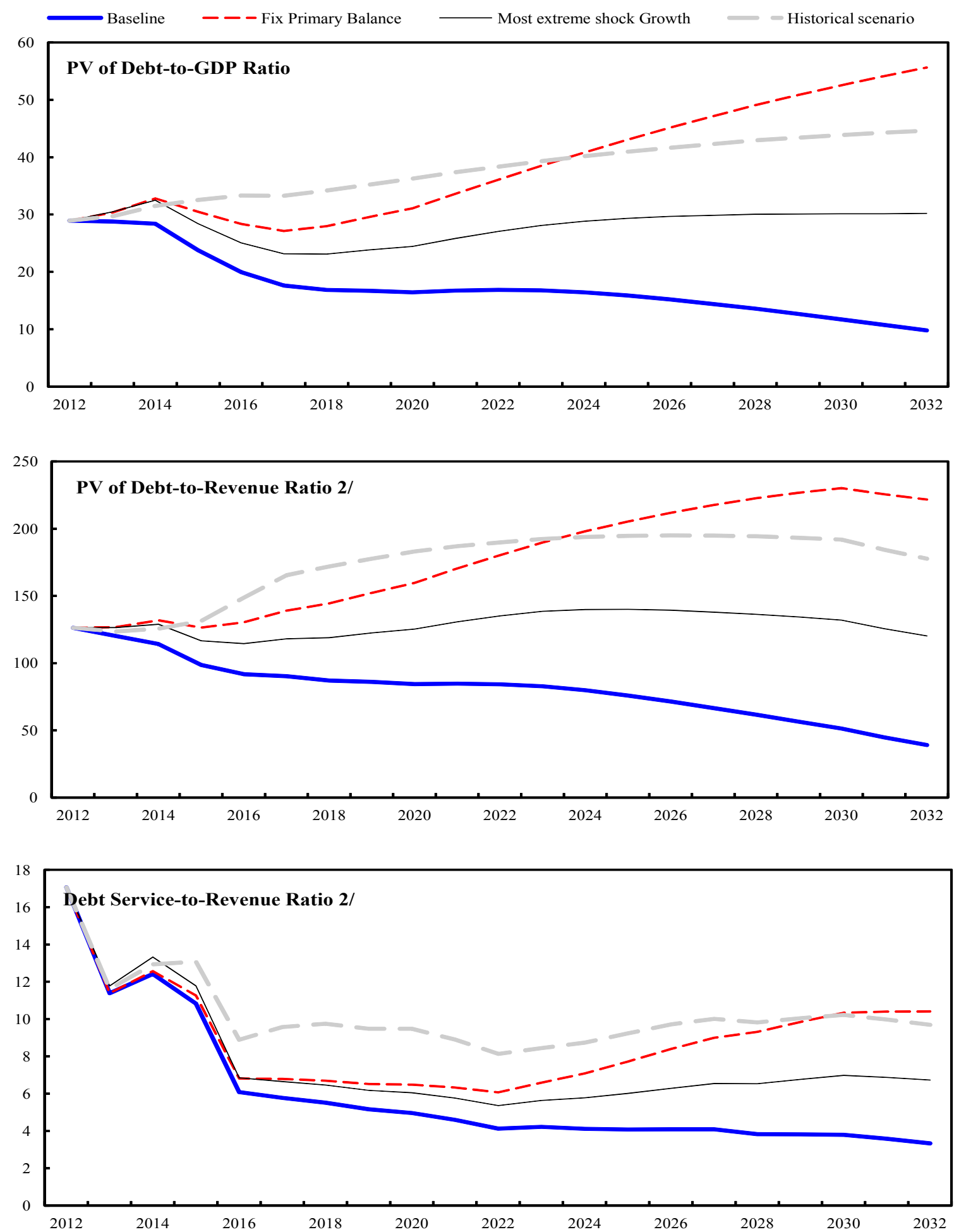

Sources: Country authorities; and staff estimates and projections.

$1 /$ The most extreme stress test is the test that yields the highest ratio in 2022 .

$2 /$ Revenues are defined inclusive of grants. 
Table 1.: External Debt Sustainability Framework, Baseline Scenario, 2009-2032 1/

(In percent of GDP, unless otherwise indicated)

\begin{tabular}{|c|c|c|c|c|c|c|c|c|c|c|c|c|c|c|c|}
\hline & \multicolumn{3}{|c|}{ Actual } & \multirow{2}{*}{$\begin{array}{l}\text { Historical } \\
\text { Average }\end{array}$} & \multirow{2}{*}{$\begin{array}{l}\text { Standard } \\
\text { Deviation }\end{array}$} & \multicolumn{6}{|c|}{ Projections } & \multirow[b]{2}{*}{$\begin{array}{c}\begin{array}{c}2012-2017 \\
\text { Average }\end{array} \\
\end{array}$} & \multirow[b]{2}{*}{2022} & \multirow[b]{2}{*}{2032} & \multirow[b]{2}{*}{$\begin{array}{c}2018-2032 \\
\text { Average }\end{array}$} \\
\hline & 2009 & 2010 & 2011 & & & 2012 & 2013 & 2014 & 2015 & 2016 & 2017 & & & & \\
\hline External debt (nominal) 1/ & 71.5 & 70.5 & 65.9 & & & 19.0 & 17.9 & 18.3 & 14.8 & 13.4 & 13.0 & & 16.3 & 9.7 & \\
\hline $\mathrm{o} / \mathrm{w}$ public and publicly guaranteed (PPG) & 71.5 & 70.5 & 65.9 & & & 19.0 & 17.9 & 18.3 & 14.8 & 13.4 & 13.0 & & 16.3 & 9.7 & \\
\hline Change in external debt & -6.0 & -1.0 & -4.5 & & & -46.9 & -1.2 & 0.4 & -3.5 & -1.4 & -0.4 & & 0.6 & -1.0 & \\
\hline Identified net debt-creating flows & 4.9 & 5.7 & 3.7 & & & 7.3 & 3.0 & 4.0 & -6.1 & -6.8 & -5.3 & & -1.9 & 0.6 & \\
\hline Non-interest current account deficit & 9.2 & 11.6 & 15.6 & 5.9 & 5.9 & 38.4 & 39.5 & 40.6 & 22.4 & 5.0 & -0.4 & & 2.1 & 5.5 & 2.7 \\
\hline Deficit in balance of goods and services & 4.3 & 8.2 & 17.9 & & & 36.2 & 37.0 & 36.9 & 19.7 & 2.4 & -12.9 & & -11.0 & -3.6 & \\
\hline Exports & 26.5 & 28.4 & 30.3 & & & 28.1 & 26.4 & 28.2 & 41.4 & 52.6 & 60.2 & & 61.3 & 43.9 & \\
\hline Imports & 30.8 & 36.5 & 48.2 & & & 64.3 & 63.5 & 65.2 & 61.1 & 55.0 & 47.3 & & 50.3 & 40.4 & \\
\hline Net current transfers (negative $=$ inflow) & -5.3 & -5.1 & -10.4 & -6.3 & 2.7 & -5.9 & -5.6 & -4.6 & -4.4 & -3.7 & -3.2 & & -2.5 & -1.9 & -2.4 \\
\hline o/w official & 0.0 & 0.0 & -2.2 & & & -0.8 & -1.0 & 0.0 & 0.0 & 0.0 & 0.0 & & 0.0 & 0.0 & \\
\hline Other current account flows (negative $=$ net inflow) & 10.3 & 8.6 & 8.1 & & & 8.1 & 8.1 & 8.2 & 7.1 & 6.2 & 15.7 & & 15.7 & 11.0 & \\
\hline Net FDI (negative $=$ inflow) & -3.0 & -2.4 & -9.5 & -4.3 & 3.0 & -28.9 & -35.8 & -35.9 & -25.7 & -9.6 & -3.5 & & -3.8 & -4.7 & -4.1 \\
\hline Endogenous debt dynamics 2/ & -1.3 & -3.5 & -2.4 & & & -2.3 & -0.7 & -0.7 & -2.8 & -2.2 & -1.4 & & -0.2 & -0.2 & \\
\hline Contribution from nominal interest rate & 0.7 & 0.7 & 0.9 & & & 0.6 & 0.2 & 0.2 & 0.2 & 0.2 & 0.2 & & 0.2 & 0.1 & \\
\hline Contribution from real GDP growth & 0.2 & -1.3 & -2.6 & & & -2.8 & -0.9 & -0.9 & -3.0 & -2.4 & -1.6 & & -0.4 & -0.3 & \\
\hline Contribution from price and exchange rate changes & -2.2 & -3.0 & -0.7 & & & & & & & & & & & & \\
\hline $\begin{array}{l}\text { Residual (3-4) 3/ } \\
\text { o/w exceptional financing }\end{array}$ & -10.9 & -6.7 & $\begin{array}{l}-8.2 \\
-1.3\end{array}$ & & & -54.2 & -4.2 & -3.6 & $\begin{array}{l}2.6 \\
0.0\end{array}$ & 5.4 & 5.0 & & 2.5 & -1.6 & \\
\hline $\begin{array}{l}\text { PV of external debt 4/ } \\
\end{array}$ & $\ldots$ & $\ldots$ & 37.1 & & & 14.9 & 13.8 & 13.8 & 11.0 & 9.8 & 9.4 & & 11.8 & 7.4 & \\
\hline In percent of exports & $\ldots$ & $\ldots$ & 122.4 & & & 53.2 & 52.2 & 49.0 & 26.5 & 18.6 & 15.6 & & 19.3 & 16.9 & \\
\hline PV of PPG external debt & ... & ... & 37.1 & & & 14.9 & 13.8 & 13.8 & 11.0 & 9.8 & 9.4 & & 11.8 & 7.4 & \\
\hline In percent of exports & ... & $\ldots$ & 122.4 & & & $\mathbf{5 3 . 2}$ & $\mathbf{5 2 . 2}$ & 49.0 & 26.5 & 18.6 & 15.6 & & 19.3 & 16.9 & \\
\hline In percent of government revenues & $\ldots$ & $\ldots$ & 220.8 & & & $\mathbf{7 8 . 0}$ & 68.5 & 66.7 & 51.9 & 48.3 & 50.6 & & 59.7 & 29.6 & \\
\hline Debt service-to-exports ratio (in percent) & 9.8 & 10.3 & 14.0 & & & 9.4 & 5.7 & 5.8 & 3.7 & 0.9 & 0.7 & & 0.8 & 1.7 & \\
\hline PPG debt service-to-exports ratio (in percent) & 9.8 & 10.3 & 14.0 & & & 9.4 & 5.7 & 5.8 & 3.7 & 0.9 & 0.7 & & 0.8 & 1.7 & \\
\hline PPG debt service-to-revenue ratio (in percent) & 16.1 & 19.2 & 25.3 & & & 13.7 & 7.5 & 7.9 & 7.3 & 2.3 & 2.3 & & 2.3 & 3.0 & \\
\hline Total gross financing need (Billions of U.S. dollars) & 0.4 & 0.6 & 0.5 & & & 0.7 & 0.3 & 0.4 & -0.1 & -0.4 & -0.4 & & -0.2 & 0.3 & \\
\hline Non-interest current account deficit that stabilizes debt ratio & 15.2 & 12.7 & 20.1 & & & 85.3 & 40.7 & 40.2 & 25.9 & 6.4 & 0.0 & & 1.5 & 6.5 & \\
\hline \multicolumn{16}{|l|}{ Key macroeconomic assumptions } \\
\hline Real GDP growth (in percent) & -0.3 & 1.9 & 3.9 & 2.7 & 1.7 & 4.8 & 5.0 & 5.2 & 19.9 & 19.7 & 14.3 & 11.5 & 2.6 & 3.1 & 3.6 \\
\hline GDP deflator in US dollar terms (change in percent) & 2.9 & 4.3 & 0.9 & 4.5 & 15.8 & 6.0 & 3.4 & -5.8 & 0.9 & 0.9 & 3.3 & 1.4 & 0.9 & 1.4 & 1.1 \\
\hline Effective interest rate (percent) $5 /$ & 0.9 & 1.1 & 1.3 & 1.4 & 0.3 & 0.9 & 1.0 & 1.2 & 1.4 & 1.5 & 1.6 & 1.3 & 1.6 & 1.4 & 1.5 \\
\hline Growth of exports of G\&S (US dollar terms, in percent) & -22.1 & 13.6 & 12.1 & 7.8 & 14.4 & 3.0 & 2.2 & 5.8 & 77.5 & 53.3 & 35.1 & 29.5 & 0.9 & 1.0 & 2.7 \\
\hline Growth of imports of G\&S (US dollar terms, in percent) & -21.2 & 26.2 & 38.3 & 12.5 & 16.6 & 48.3 & 7.2 & 1.7 & 13.4 & 8.8 & 1.4 & 13.5 & 1.5 & 4.3 & 3.8 \\
\hline Grant element of new public sector borrowing (in percent) & & & & & & 39.7 & 39.7 & 39.7 & 39.7 & 39.7 & 39.7 & 39.7 & 33.4 & 30.3 & 31.9 \\
\hline Government revenues (excluding grants, in percent of GDP) & 16.2 & 15.3 & 16.8 & & & 19.2 & 20.2 & 20.8 & 21.1 & 20.3 & 18.5 & & 19.8 & 25.1 & 21.1 \\
\hline Aid flows (in Billions of US dollars) $7 /$ & 0.0 & 0.0 & 0.2 & & & 0.3 & 0.3 & 0.3 & 0.3 & 0.2 & 0.2 & & 0.1 & 0.0 & \\
\hline $\mathrm{o} / \mathrm{w}$ Grants & 0.0 & 0.0 & 0.2 & & & 0.2 & 0.2 & 0.3 & 0.2 & 0.1 & 0.1 & & 0.0 & 0.0 & \\
\hline $\mathrm{o} / \mathrm{w}$ Concessional loans & 0.0 & 0.0 & 0.0 & & & 0.1 & 0.1 & 0.1 & 0.0 & 0.1 & 0.1 & & 0.1 & 0.0 & \\
\hline Grant-equivalent financing (in percent of GDP) $8 /$ & $\ldots$ & $\ldots$ & $\ldots$ & & & 5.0 & 4.4 & 4.7 & 3.4 & 2.0 & 1.8 & & 0.7 & 0.0 & 0.5 \\
\hline Grant-equivalent financing (in percent of external financing) 8/ & & $\ldots$ & & & & 72.6 & 81.8 & 83.6 & 84.5 & 70.9 & 60.4 & & 43.4 & 41.2 & 44.6 \\
\hline \multicolumn{16}{|l|}{ Memorandum items: } \\
\hline Nominal GDP (Billions of US dollars) & 4.6 & 4.9 & 5.2 & & & 5.7 & 6.2 & 6.2 & 7.5 & 9.0 & 10.7 & & 14.3 & 21.4 & \\
\hline Nominal dollar GDP growth & 2.6 & 6.3 & 4.9 & & & 11.1 & 8.6 & -0.9 & 21.0 & 20.8 & 18.1 & 13.1 & 3.5 & 4.5 & 4.8 \\
\hline PV of PPG external debt (in Billions of US dollars) & & & 1.8 & & & 0.8 & 0.8 & 0.8 & 0.8 & 0.9 & 1.0 & & 1.7 & 1.6 & \\
\hline (PVt-PVt-1)/GDPt-1 (in percent) & & & & & & -0.2 & 0.0 & -0.2 & -0.6 & 0.9 & 1.2 & 0.2 & 0.9 & -0.4 & 0.4 \\
\hline Gross workers' remittances (Billions of US dollars) & $\cdots$ & $\cdots$ & & & & & & & & & & & & & \\
\hline PV of PPG external debt (in percent of GDP + remittances) & $\ldots$ & $\ldots$ & 37.1 & & & 14.9 & 13.8 & 13.8 & 11.0 & 9.8 & 9.4 & & 11.8 & 7.4 & \\
\hline PV of PPG external debt (in percent of exports + remittances) & $\ldots$ & $\ldots$ & 122.4 & & & 53.2 & 52.2 & 49.0 & 26.5 & 18.6 & 15.6 & & 19.3 & 16.9 & \\
\hline Debt service of PPG external debt (in percent of exports + remittances) & $\ldots$ & $\ldots$ & 14.0 & & & 9.4 & 5.7 & 5.8 & 3.7 & 0.9 & 0.7 & & 0.8 & 1.7 & \\
\hline
\end{tabular}

Sources: Country authorities; and staff estimates and projections.

$1 /$ Includes both public and private sector external debt.

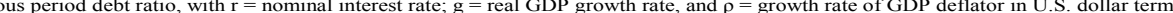

3/ Includes exceptional financing (i.e., changes in arrears and debt relief); changes in gross foreign assets; and valuation adjustments. For projections also includes contribution from price and exchange rate changes. 4/ Assumes that PV of private sector debt is equivalent to its face value.
$5 /$ Current-year interest payments divided by previous period debt stock.

6/ Historical averages and standard deviations are generally derived over the past 10 years, subject to data availability.

8/ Grant-equivalent financing includes grants provided directly to the government and through new borrowing (difference between the face value and the PV of new debt). 
Table 2.Guinea: Sensitivity Analysis for Key Indicators of Public and Publicly Guaranteed External Debt, 2012-2032

(In percent)

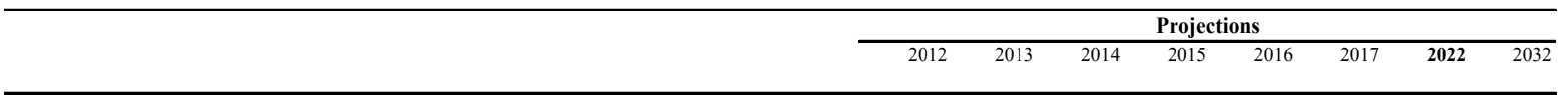

PV of debt-to GDP ratio

Baseline

A. Alternative Scenarios

A1. Key variables at their historical averages in 2012-2032 1 /

A2. New public sector loans on less favorable terms in 2012-2032 2

\section{B. Bound Tests}

B1. Real GDP growth at historical average minus one standard deviation in 2013-2014

B2. Export value growth at historical average minus one standard deviation in 2013-2014 3/

B3. US dollar GDP deflator at historical average minus one standard deviation in 2013-2014

B4. Net non-debt creating flows at historical average minus one standard deviation in 2013-2014 4/

B5. Combination of B1-B4 using one-half standard deviation shocks

B6. One-time 30 percent nominal depreciation relative to the baseline in 2013 5/
15

15

15

$\begin{array}{rrrrrrr}12 & 9 & 11 & 16 & 19 & \mathbf{3 1} & 30 \\ 14 & 15 & 12 & 11 & 11 & \mathbf{1 6} & 12\end{array}$

PV of debt-to-exports ratio

Baseline

A1. Key variables at their historical averages in 2012-2032 1/

A2. New public sector loans on less favorable terms in 2012-2032 2

\section{B. Bound Tests}

B1. Real GDP growth at historical average minus one standard deviation in 2013-2014 B2. Export value growth at historical average minus one standard deviation in 2013-2014 3/

B3. US dollar GDP deflator at historical average minus one standard deviation in 2013-2014

B4. Net non-debt creating flows at historical average minus one standard deviation in 2013-2014 4/

B5. Combination of B1-B4 using one-half standard deviation shocks

B6. One-time 30 percent nominal depreciation relative to the baseline in 2013 5/

\section{PV of debt-to-revenue ratio}

Baseline

68

67

52

48

51

60

30

\section{A. Alternative Scenarios}

A1. Key variables at their historical averages in 2012-2032 1/

A2. New public sector loans on less favorable terms in 2012-2032 2

$\begin{array}{rrrrrrrr}78 & 61 & 44 & 54 & 77 & 105 & \mathbf{1 5 7} & 121 \\ 78 & 70 & 70 & 56 & 54 & 60 & \mathbf{7 8} & 48\end{array}$

B. Bound Tests

B1. Real GDP growth at historical average minus one standard deviation in 2013-2014

B2. Export value growth at historical average minus one standard deviation in 2013-2014 3/

B3. US dollar GDP deflator at historical average minus one standard deviation in 2013-2014

B4. Net non-debt creating flows at historical average minus one standard deviation in 2013-2014 4/

B5. Combination of B1-B4 using one-half standard deviation shocks

B6. One-time 30 percent nominal depreciation relative to the baseline in 20135 ,

$\begin{array}{rrrrrrr}70 & 71 & 55 & 51 & 54 & \mathbf{6 3} & 31 \\ 75 & 91 & 73 & 67 & 68 & \mathbf{7 3} & 35 \\ 79 & 81 & 63 & 59 & 61 & \mathbf{7 2} & 36 \\ 191 & 308 & 255 & 229 & 223 & \mathbf{1 9 7} & 82 \\ 205 & 335 & 277 & 249 & 243 & \mathbf{2 1 5} & 89 \\ 95 & 92 & 72 & 67 & 70 & \mathbf{8 2} & 41\end{array}$


Table 2.Guinea: Sensitivity Analysis for Key Indicators of Public and Publicly Guaranteed External Debt, 2012-2032 (continued) (In percent)

Debt service-to-exports ratio

A. Alternative Scenarios

A1. Key variables at their historical averages in 2012-2032

A2. New public sector loans on less favorable terms in 2012-2032 2

B. Bound Tests

B1. Real GDP growth at historical average minus one standard deviation in 2013-2014

B2. Export value growth at historical average minus one standard deviation in 2013-2014 3 /

B3. US dollar GDP deflator at historical average minus one standard deviation in 2013-2014

B4. Net non-debt creating flows at historical average minus one standard deviation in 2013-2014 4/

B5. Combination of B1-B4 using one-half standard deviation shocks

B6. One-time 30 percent nominal depreciation relative to the baseline in 20135

\section{Debt service-to-revenue ratio}

Baseline

\section{A. Alternative Scenarios}

A1. Key variables at their historical averages in 2012-2032 1/

A2. New public sector loans on less favorable terms in 2012-2032 2

$\begin{array}{llllllll}14 & 8 & 7 & 7 & 3 & 4 & \mathbf{4} & 7 \\ 14 & 7 & 8 & 7 & 2 & 3 & \mathbf{3} & 4\end{array}$

B. Bound Tests

B1. Real GDP growth at historical average minus one standard deviation in 2013-2014

B2. Export value growth at historical average minus one standard deviation in 2013-2014 3/

B3. US dollar GDP deflator at historical average minus one standard deviation in 2013-2014

B4. Net non-debt creating flows at historical average minus one standard deviation in 2013-2014 4/

B5. Combination of B1-B4 using one-half standard deviation shocks

B6. One-time 30 percent nominal depreciation relative to the baseline in 20135 /

Memorandum item

Grant element assumed on residual financing (i.e., financing required above baseline) 6 /

$\begin{array}{rrrrrrrr}14 & 8 & 9 & 8 & 3 & 3 & \mathbf{3} & 3 \\ 14 & 7 & 8 & 8 & 3 & 3 & \mathbf{3} & 4 \\ 14 & 9 & 10 & 9 & 3 & 3 & \mathbf{3} & 4 \\ 14 & 7 & 11 & 12 & 6 & 6 & \mathbf{9} & 9 \\ 14 & 8 & 12 & 13 & 7 & 6 & \mathbf{1 0} & 9 \\ 14 & 11 & 11 & 10 & 3 & 3 & \mathbf{3} & 4 \\ & & & & & & & \\ 32 & 32 & 32 & 32 & 32 & 32 & \mathbf{3 2} & 32\end{array}$

Sources: Country authorities; and staff estimates and projections.

1/ Variables include real GDP growth, growth of GDP deflator (in U.S. dollar terms), non-interest current account in percent of GDP, and non-debt creating flows.

2/ Assumes that the interest rate on new borrowing is by 2 percentage points higher than in the baseline., while grace and maturity periods are the same as in the baseline.

3/ Exports values are assumed to remain permanently at the lower level, but the current account as a share of GDP is assumed to return to its baseline level after the shock (implicitly assuming

an offsetting adjustment in import levels).

4/ Includes official and private transfers and FDI.

5/ Depreciation is defined as percentage decline in dollar/local currency rate, such that it never exceeds 100 percent.

6/ Applies to all stress scenarios except for A2 (less favorable financing) in which the terms on all new financing are as specified in footnote 2. 
Table 3.Guinea: Public Sector Debt Sustainability Framework, Baseline Scenario, 2009-2032

(In percent of GDP, unless otherwise indicated)

\begin{tabular}{|c|c|c|c|c|c|c|c|c|c|c|c|c|c|c|c|}
\hline & \multicolumn{3}{|c|}{ Actual } & \multirow[b]{2}{*}{ Average ${ }^{5 /}$} & \multirow[b]{2}{*}{$\begin{array}{c}\text { Standard } \\
\text { Deviation } \\
\end{array}$} & \multicolumn{4}{|l|}{ Estimate } & \multicolumn{3}{|c|}{ Projections } & \multirow[b]{2}{*}{2022} & \multirow[b]{2}{*}{2032} & \multirow[b]{2}{*}{$\begin{array}{l}2018-32 \\
\text { Average }\end{array}$} \\
\hline & 2009 & 2010 & 2011 & & & 2012 & 2013 & 2014 & 2015 & 2016 & 2017 & $\begin{array}{l}2012-17 \\
\text { Average }\end{array}$ & & & \\
\hline $\begin{array}{l}\text { Public sector debt } 1 / \\
\text { o/w foreign-currency denominated }\end{array}$ & $\begin{array}{l}90.1 \\
71.5\end{array}$ & $\begin{array}{r}100.7 \\
70.5\end{array}$ & $\begin{array}{l}76.8 \\
65.9\end{array}$ & & & $\begin{array}{l}33.0 \\
19.0\end{array}$ & $\begin{array}{l}32.9 \\
17.9\end{array}$ & $\begin{array}{l}32.8 \\
18.3\end{array}$ & $\begin{array}{l}27.6 \\
14.8\end{array}$ & $\begin{array}{l}23.5 \\
13.4\end{array}$ & $\begin{array}{l}21.3 \\
13.0\end{array}$ & & $\begin{array}{l}21.4 \\
16.3\end{array}$ & $\begin{array}{r}12.1 \\
9.7\end{array}$ & \\
\hline Change in public sector debt & 0.2 & 10.6 & -23.9 & & & -43.8 & -0.2 & 0.0 & -5.3 & -4.1 & -2.3 & & 0.2 & -1.2 & \\
\hline Identified debt-creating flows & -1.7 & 11.1 & -11.4 & & & -43.5 & -0.3 & -0.4 & -5.5 & -4.3 & -2.4 & & 0.0 & -1.2 & \\
\hline Primary deficit & 5.0 & 12.0 & -0.6 & 2.0 & 4.4 & 4.0 & 1.6 & -0.2 & -0.4 & 0.0 & 0.8 & 1.0 & 0.5 & -0.8 & -0.1 \\
\hline Revenue and grants & 16.5 & 15.7 & 20.3 & & & 22.9 & 23.9 & 24.9 & 24.1 & 21.8 & 19.5 & & 20.0 & 25.1 & \\
\hline of which: grants & 0.4 & 0.4 & 3.4 & & & 3.7 & 3.8 & 4.1 & 3.0 & 1.5 & 1.0 & & 0.2 & 0.0 & \\
\hline Primary (noninterest) expenditure & 21.6 & 27.7 & 19.6 & & & 26.9 & 25.6 & 24.7 & 23.7 & 21.8 & 20.3 & & 20.5 & 24.3 & \\
\hline Automatic debt dynamics & -6.7 & -0.8 & -9.5 & & & -10.1 & -1.9 & -0.2 & -5.1 & -4.3 & -3.2 & & -0.5 & -0.4 & \\
\hline Contribution from interest rate/growth differential & 0.8 & -3.5 & -8.0 & & & -4.2 & -1.6 & -1.6 & -5.2 & -4.4 & -3.0 & & -0.6 & -0.5 & \\
\hline of which: contribution from average real interest rate & 0.6 & -1.8 & -4.2 & & & -0.7 & -0.1 & 0.0 & 0.3 & 0.2 & -0.1 & & -0.1 & -0.1 & \\
\hline of which: contribution from real GDP growth & 0.3 & -1.7 & -3.8 & & & -3.5 & -1.6 & -1.6 & -5.4 & -4.5 & -2.9 & & -0.5 & -0.4 & \\
\hline Contribution from real exchange rate depreciation & -7.5 & 2.7 & -1.5 & & & -5.8 & -0.3 & 1.4 & 0.1 & 0.1 & -0.2 & & $\ldots$ & $\ldots$ & \\
\hline Other identified debt-creating flows & 0.0 & -0.1 & -1.3 & & & -37.5 & 0.0 & 0.0 & 0.0 & 0.0 & 0.0 & & 0.0 & 0.0 & \\
\hline Privatization receipts (negative) & 0.0 & 0.0 & 0.0 & & & 0.0 & 0.0 & 0.0 & 0.0 & 0.0 & 0.0 & & 0.0 & 0.0 & \\
\hline Recognition of implicit or contingent liabilities & 0.0 & 0.0 & 0.0 & & & 0.0 & 0.0 & 0.0 & 0.0 & 0.0 & 0.0 & & 0.0 & 0.0 & \\
\hline Debt relief (HIPC and other) & 0.0 & -0.1 & -1.3 & & & -37.5 & 0.0 & 0.0 & 0.0 & 0.0 & 0.0 & & 0.0 & 0.0 & \\
\hline Other (specify, e.g. bank recapitalization) & 0.0 & 0.0 & 0.0 & & & 0.0 & 0.0 & 0.0 & 0.0 & 0.0 & 0.0 & & 0.0 & 0.0 & \\
\hline Residual, including asset changes & 1.9 & -0.5 & -12.4 & & & -0.3 & 0.1 & 0.3 & 0.3 & 0.2 & 0.2 & & 0.2 & 0.0 & \\
\hline \multicolumn{16}{|l|}{ Other Sustainability Indicators } \\
\hline PV of public sector debt & $\ldots$ & $\ldots$ & 48.0 & & & 28.9 & 28.8 & 28.4 & 23.8 & 20.0 & 17.6 & & 16.8 & 9.8 & \\
\hline $\mathrm{o} / \mathrm{w}$ foreign-currency denominated & $\ldots$ & $\ldots$ & 37.1 & & & 14.9 & 13.8 & 13.8 & 11.0 & 9.8 & 9.4 & & 11.8 & 7.4 & \\
\hline $\mathrm{o} / \mathrm{w}$ external & & & 37.1 & & & 14.9 & 13.8 & 13.8 & 11.0 & 9.8 & 9.4 & & 11.8 & 7.4 & \\
\hline PV of contingent liabilities (not included in public sector debt) & $\ldots$ & $\ldots$ & & & & $\ldots$ & $\ldots$ & $\ldots$ & $\ldots$ & $\ldots$ & $\ldots$ & & $\ldots$ & & \\
\hline Gross financing need $2 /$ & 9.3 & 16.7 & 4.7 & & & 7.9 & 4.4 & 2.9 & 2.2 & 1.3 & 1.9 & & 1.3 & 0.1 & \\
\hline PV of public sector debt-to-revenue and grants ratio (in percent) & $\ldots$ & $\ldots$ & 237.0 & & & 126.2 & 120.2 & 114.2 & 98.6 & 91.8 & 90.4 & & 84.2 & 39.1 & \\
\hline $\mathrm{PV}$ of public sector debt-to-revenue ratio (in percent) & $\ldots$ & $\ldots$ & 285.7 & & & 150.9 & 142.9 & 136.9 & 112.6 & 98.5 & 95.3 & & 85.2 & 39.1 & \\
\hline o/w external 3/ & $\ldots$ & & 220.8 & & & 78.0 & 68.5 & 66.7 & 51.9 & 48.3 & 50.6 & & 59.7 & 29.6 & \\
\hline Debt service-to-revenue and grants ratio (in percent) $4 /$ & 25.7 & 30.0 & 26.5 & & & 17.1 & 11.4 & 12.4 & 10.8 & 6.1 & 5.8 & & 4.1 & 3.3 & \\
\hline Debt service-to-revenue ratio (in percent) $4 /$ & 26.3 & 30.7 & 31.9 & & & 20.4 & 13.5 & 14.9 & 12.4 & 6.5 & 6.1 & & 4.2 & 3.3 & \\
\hline Primary deficit that stabilizes the debt-to-GDP ratio & 4.9 & 1.3 & 23.3 & & & 47.8 & 1.8 & -0.2 & 4.8 & 4.1 & 3.0 & & 0.2 & 0.4 & \\
\hline \multicolumn{16}{|l|}{ Key macroeconomic and fiscal assumptions } \\
\hline Real GDP growth (in percent) & -0.3 & 1.9 & 3.9 & 2.7 & 1.7 & 4.8 & 5.0 & 5.2 & 19.9 & 19.7 & 14.3 & 11.5 & 2.6 & 3.1 & 3.6 \\
\hline Average nominal interest rate on forex debt (in percent) & 0.9 & 1.1 & 1.3 & 1.4 & 0.3 & 0.9 & 1.0 & 1.2 & 1.4 & 1.5 & 1.6 & 1.3 & 1.6 & 1.4 & 1.5 \\
\hline Average real interest rate on domestic debt (in percent) & 5.4 & -9.6 & -12.6 & -3.2 & 7.5 & -4.8 & 0.2 & 0.5 & 2.4 & 1.8 & -0.6 & -0.1 & -0.4 & -1.6 & -0.4 \\
\hline Real exchange rate depreciation (in percent,+ indicates depreciation) & -9.7 & 3.9 & -2.3 & 1.0 & 19.6 & -9.3 & & $\ldots$ & & $\ldots$ & & $\ldots$ & $\ldots$ & $\ldots$ & $\ldots$ \\
\hline Inflation rate (GDP deflator, in percent) & 6.8 & 20.2 & 19.6 & 17.2 & 10.3 & 14.7 & 6.3 & 7.4 & 5.2 & 5.0 & 7.4 & 7.7 & 4.8 & 5.3 & 5.0 \\
\hline Growth of real primary spending (deflated by GDP deflator, in percent) & 0.5 & 0.3 & -0.3 & 0.1 & 0.2 & 0.4 & 0.0 & 0.0 & 0.1 & 0.1 & 0.1 & 0.1 & 0.0 & 0.1 & 0.0 \\
\hline Grant element of new external borrowing (in percent) & & & & $\ldots$ & $\ldots$ & 39.7 & 39.7 & 39.7 & 39.7 & 39.7 & 39.7 & 39.7 & 33.4 & 30.3 & $\ldots$ \\
\hline
\end{tabular}

Sources: Country authorities; and staff estimates and projection

列

$3 /$ Revenues excluding grants.

4/ Debt service is defined as the sum of interest and amortization of medium and long-term debt.

$5 /$ Historical averages and standard deviations are generally derived over the past 10 years, subject to data availability 
Table 4.Guinea: Sensitivity Analysis for Key Indicators of Public Debt 2012-2032

\begin{tabular}{llllllll}
2012 & 2013 & 2014 & 2015 & 2016 & 2017 & 2022 & 2032 \\
\hline
\end{tabular}

\section{PV of Debt-to-GDP Ratio}

Baseline

$\begin{array}{llllllll}29 & 29 & 28 & 24 & 20 & 18 & 17 & 10\end{array}$

A. Alternative scenarios

A1. Real GDP growth and primary balance are at historical averages

A2. Primary balance is unchanged from 2012

A3. Permanently lower GDP growth $1 /$

$\begin{array}{llllllll}29 & 30 & 32 & 33 & 33 & 33 & 38 & 45\end{array}$

$\begin{array}{llllllll}29 & 30 & 33 & 30 & 28 & 27 & 36 & 56\end{array}$

\section{B. Bound tests}

B1. Real GDP growth is at historical average minus one standard deviations in 2013-2014

B2. Primary balance is at historical average minus one standard deviations in 2013-2014

B3. Combination of B1-B2 using one half standard deviation shocks

B4. One-time 30 percent real depreciation in 2013

B5. 10 percent of GDP increase in other debt-creating flows in 2013

PV of Debt-to-Revenue Ratio 2/

Baseline

$\begin{array}{llllllll}126 & 120 & 114 & 99 & 92 & 90 & 84 & 39\end{array}$

A. Alternative scenarios

A1. Real GDP growth and primary balance are at historical averages

A2. Primary balance is unchanged from 2012

A3. Permanently lower GDP growth $1 /$

$\begin{array}{llllllll}126 & 124 & 126 & 131 & 149 & 165 & 190 & 178\end{array}$

$\begin{array}{llllllll}126 & 127 & 132 & 126 & 130 & 139 & 180 & 222\end{array}$

B. Bound tests

B1. Real GDP growth is at historical average minus one standard deviations in 2013-2014

B2. Primary balance is at historical average minus one standard deviations in 2013-2014

B3. Combination of B1-B2 using one half standard deviation shocks

B4. One-time 30 percent real depreciation in 2013

B5. 10 percent of GDP increase in other debt-creating flows in 2013

Debt Service-to-Revenue Ratio 2/

Baseline

$\begin{array}{llllllll}17 & 11 & 12 & 11 & 6 & 6 & 4 & 3\end{array}$

\section{A. Alternative scenarios}

A1. Real GDP growth and primary balance are at historical averages

A2. Primary balance is unchanged from 2012

A3. Permanently lower GDP growth 1/

$\begin{array}{rrrrrrrr}17 & 12 & 13 & 13 & 9 & 10 & 8 & 10 \\ 17 & 11 & 13 & 11 & 7 & 7 & 6 & 10 \\ 17 & 11 & 12 & 11 & 6 & 6 & 4 & 5\end{array}$

\section{B. Bound tests}

B1. Real GDP growth is at historical average minus one standard deviations in 2013-2014

B2. Primary balance is at historical average minus one standard deviations in 2013-2014

B3. Combination of B1-B2 using one half standard deviation shocks

B4. One-time 30 percent real depreciation in 2013

B5. 10 percent of GDP increase in other debt-creating flows in 2013

$\begin{array}{llllllll}17 & 12 & 13 & 12 & 7 & 7 & 5 & 7 \\ 17 & 11 & 13 & 12 & 7 & 6 & 5 & 4 \\ 17 & 12 & 13 & 12 & 7 & 7 & 5 & 6 \\ 17 & 13 & 15 & 14 & 7 & 7 & 5 & 5 \\ 17 & 11 & 13 & 12 & 7 & 6 & 5 & 4\end{array}$

Sources: Country authorities; and staff estimates and projections.

1/ Assumes that real GDP growth is at baseline minus one standard deviation divided by the square root of the length of the projection period.

2 / Revenues are defined inclusive of grants. 
This page intentionally left blank

CInternational Monetary Fund. Not for Redistribution 


\section{IMF and World Bank Announce US\$2.1 Billion Debt Relief for Guinea}

WASHINGTON-The International Monetary Fund (IMF) and the World Bank's International Development Association (IDA) have decided to support US\$2.1 billion in debt relief for Guinea, representing a 66 percent reduction of its future external debt service over a period of 40 years. ${ }^{1}$

The Boards of Directors of both institutions ${ }^{2}$ determined that Guinea has made satisfactory progress in meeting the requirements to reach the completion point under the Heavily Indebted Poor Countries (HIPC) Initiative, the stage at which the HIPC debt relief becomes irrevocable and the country will benefit from the Multilateral Debt Relief Initiative (MDRI).

The requirements met by Guinea included, among others, the preparation and satisfactory implementation of a Poverty Reduction Strategy Paper (PRSP), the maintenance of a sound macroeconomic policy framework, the improvement of a poverty database and monitoring capacity, the publication of annual reports on the activities of the Anti-Corruption Agency, an increase in gross enrolment rates in primary schools, and an increase in immunization rates for children. Guinea was granted a waiver on the trigger related to audits of large government procurement contracts, as the broad objective of this requirement was achieved and implementation has improved.

"Reaching the HIPC completion point represents an important achievement for Guinea. It reflects the significant progress made in economic management following the first democratic elections in December 2010," said Harry Snoek, IMF mission chief for Guinea. "Reaching the completion point will help Guinea allocate more resources for poverty reduction and economic growth. Sound macroeconomic management will remain critical after the completion point to make the most of Guinea's abundant mining resources and other growth potentials, " Mr. Snoek said.

\footnotetext{
${ }^{1}$ The figures represent staff estimate of effective debt relief.

2 The IDA Executive Board met on September 25, 2012, and the IMF Executive Board met on September 26, 2012.
}

Washington, D.C. 20431 • Telephone 202-623-7100 • Fax 202-623-6772 • www.imf.org 
"Full debt relief is a tremendous development opportunity for Guinea, as this will help the country achieve economic stability and devote more resources to reduce poverty," said

Ousmane Diagana, World Bank Director for Guinea. "We will continue to support Guinea in strengthening financial management, transparency and accountability to turn debt relief into visible development outcomes such as better health, education, environmental preservation and infrastructure for sustainable and inclusive growth," Mr. Diagana said.

Of the resulting reduction of about US\$2.1 billion, about 70 percent will come from multilateral creditors, and the remaining from bilateral and commercial creditors. MDRI relief provided by the World Bank's IDA and the African Development Bank Group would save Guinea US\$964 million in debt service over 40 years. There remain no loans eligible for MDRI relief from the IMF.

Full delivery of debt relief (HIPC Initiative, MDRI, and additional bilateral assistance at the completion point) will considerably reduce the debt burden of Guinea. The annual external debt service will fall by 70 percent, from an average of US\$170 million for the period 2012-21 to US\$49 million. Nevertheless, both the IMF and the World Bank consider that the improved Guinea's debt indicators will be sensitive to export levels and the terms of new external financing, underlining the need for sound macroeconomic management, further progress with structural reform, and strengthened debt management.

Guinea becomes the 34 th country to reach the completion point under the HIPC Initiative. The completion point marks the end of the HIPC process, which started in 2000 when the Executive Boards of the IMF and the World Bank's IDA agreed that Guinea had met the requirements for reaching the decision point, the stage at which countries start receiving debt relief on an interim basis.

\section{ANNEX (Note to Editors)}

The HIPC Initiative. In 1996, the World Bank and IMF launched the HIPC Initiative to create a framework in which all creditors, including multilateral creditors, can provide debt relief to the world's poorest and most heavily indebted countries to ensure debt sustainability, and thereby reduce the constraints on economic growth and poverty reduction imposed by the unsustainable debt-service burdens in these countries.

To date, 36 HIPC countries have reached their decision points, of which 34 (including Guinea) have reached the completion point.

The MDRI. Created in 2005, the aim of the Multilateral Debt Relief Initiative is to reduce further the debt of eligible low-income countries and provide additional resources to help them reach the Millennium Development Goals. Under the MDRI, three multilateral institutions-the World Bank's International Development Association, the International Monetary Fund and the African Development Fund-provide 100 percent debt relief on eligible debts to qualifying countries normally at the time they reach the HIPC Initiative completion point. 
For more information on Guinea, please visit:

http://web.worldbank.org/WBSITE/EXTERNAL/COUNTRIES/AFRICAEXT/GUINEAEXTN/ 0,menuPK:351801 pagePK:141159 piPK:141110 theSitePK:351795,00.html

For more information on debt relief, please visit:

http://www.imf.org/external/np/exr/facts/hipc.htm,

http://www.imf.org/external/np/exr/facts/mdri.htm and

http://web.worldbank.org/WBSITE/EXTERNAL/TOPICS/EXTDEBTDEPT/0,

701931 menuPK:64166739 pagePK:64166689 piPK:64166646 theSitePK:469043,00.html. 


\section{Statement by Kossi Assimaidou, Executive Director for Guinea \\ September 26, 2012}

\section{INTRODUCTION}

My Guinean authorities would like to express their sincere appreciation to the Board, management and staff for the continued support to Guinea. The ongoing ECF-supported program, has enabled the country to stabilize its macroeconomic framework and lay the foundations for strong and sustainable economic growth. The authorities' strong commitment to reforms and sound policies coupled with support from the international community has led to a good performance in implementing the program, reflected by significant progress made in economic recovery and in the reduction of financial imbalances.

\section{Under the ECF-supported program, strong fiscal and monetary measures as well as} structural reforms are being implemented with positive results. In this regard, all quantitative performance criteria set out for end-June 2012 have been met, except for the continuous performance criterion on new external arrears that was missed due to technical problems experienced by the central bank with its international transfer system. My authorities are requesting a waiver for this minor nonobservance of the performance criterion on external arrears for which adequate corrective measures have been taken, including the settlement of the arrears. Considerable progress has also been made as regards structural reforms, albeit with some delays, with the technical and financial support from development partners. In addition, the authorities made important strides in establishing good governance and transparency in the mining sector.

To ensure the achievement of the program's objectives and to place Guinea on the path of strong sustainable growth, the Guinean authorities will also pursue efforts to create all required conditions conducive to these objectives, including the organization of the legislative elections that will take place before the end of the 2012 with the support of the international community. In this regard, a new law governing the Commission Electorale nationale Independante (CENI) was adopted by the interim parliament, the Conseil National de Transition (CNT) on September 17, 2012.

Based on the progress made in implementing the program and their strong commitment to sound policies and reforms, my Guinean authorities are requesting the support of the Board for the completion of the first review, the waiver for nonobservance of performance criterion on new external arrears, the modification of the performance criteria for end-December 2012 and the financing assurances review.

\section{COMPletion Point Under The ENhanCEd HIPC Initiative}

Guinea has made good progress in meeting the requirements for reaching the completion point under the HIPC Initiative. The authorities have met nine of the ten triggers, with good progress made in achieving the objectives of the remaining trigger, in regard to the audit of government procurement contracts over GNF 100 million. Capacity constraint was the main reason for missing this trigger and the authorities are requesting a waiver for it. The financing 
requirements for the program are met. Moreover, to ensure prudent debt management, the authorities will mobilize only grants and concessional loans, and will consult the IMF staff on the conditions and concessionality of all new debt agreement proposals. In addition, the authorities are committed to allocate the debt relief resources to expenditures for the priority sectors to substantially reduce poverty.

In the circumstances, my Guinean authorities would appreciate Executive Directors' approval that Guinea has met the requirements for reaching the completion point under the HIPC Initiative to enable the country to benefit from debt relief. This approval would reduce considerably Guinea's external public debt and enable the country to implement fully policies conducive to sustainable growth and poverty reduction.

\section{AChievements Under the ECF-Supported Program}

\section{The Guinean authorities' commitment to reforms and sound policies has led to a} satisfactory implementation of the ECF-supported program over the first half of 2012. Prudent fiscal and monetary policies have been steadfastly implemented to curb inflation, stabilize the exchange rate and significantly reduce the fiscal deficit. Economic activity increased due mainly to accelerating investment in agricultural and mining sector. As a result, real GDP growth in 2012 is expected to reach 4.8 percent against 3.9 percent in 2011 and 1.9 percent in 2010. Inflation decreased from 19 percent at end-2011 to below 15 percent in July 2012, and is projected to continue on a declining trend, thanks to tight liquidity management together with a cash-based public expenditure management. As for official reserves, their accumulation level exceeded 4 months of imports by end-June 2012 .

In the fiscal sector, the authorities pursued their efforts aimed at increasing revenue and containing expenditures. Budget revenue exceeded projections by 1 percentage point of GDP, helped by a strengthening of administrative measures, including the audits on fiscal years 2009 to 2012. Customs achieved its revenue target despite the losses in fuel taxes and increases in import costs. The harmonization of customs clearances at the seaports and land borders was accelerated to reduce leakages and the thorough review of tax exemptions continued for companies eligible for advantages under the investment code. As for expenditures, the authorities continued the cash-based expenditure management and were able to contain expenditures to the level required under the program. The authorities also proceeded with the retirement of more than 4000 military personnel, postponement of the implementation of special civil personnel statutes and better auditing of new employees thus generating savings in the wage bill. Their fiscal approach was very successful, in that the basic fiscal balance for the first semester of 2012 was nearly zero against a deficit target of 3.7 percent of GDP for the year.

In the structural area, important progress was made as the authorities strengthened their commitment to coordinate and monitor the structural reforms' implementation. The Council of Ministers, chaired by the Prime Minister, is playing a major role in monitoring the execution of reforms and policy measures under the program, as each minister is accountable for measures and actions for which his ministry is responsible. In this context, good progress was made in improving the public financial management with the IMF's Fiscal Affairs Department. Among others, this includes the tax reform action plan prepared in June, the adoption of a new procurement code and the organic budget law. In addition, the accounting procedures governing 
the Special Investment Fund were adopted through a presidential decree. With the technical assistance from West AFRITAC, the Central Bank strengthened the banking supervision framework and prudential regulations including those for microfinance institutions.

\section{Important strides were made in implementing policy and institutional reforms in the} mining, electricity and agricultural sectors. The framework for awarding mining titles and conventions was strengthened with the creation of the National Mining Commission supported by a strategic committee and a technical committee. The fiscal regime of the new mining code adopted in 2011 will be finalized under the FAD technical assistance. In January, an action plan to reform the electricity sector was adopted followed by the establishment of a monitoring committee to oversee and coordinate its implementation. As regards the agricultural sector, the objective is to achieve food-self-sufficiency by 2014. The harmonization of methods and procedures of assistance to the sector with those under projects supported by development partners was achieved although with some delays due to capacity constraints. The authorities are also revising the investment code together with the General Tax Code, the Customs Code and the Customs tariff with technical assistance provided by the Fund, IFC and the World Bank.

On external debt, the authorities reached in April 2012 an agreement with Paris Club creditors to benefit from relief on exceptional terms. They have also initiated discussions with other official creditors on debt restructuring under terms comparable with those of the Paris Club.

\section{POLICIES AND REFORMS FOR 2012 AND 2013}

Going forward, my Guinean authorities will pursue the implementation of prudent policies and sound reforms. In this regard, reform momentum built under the run-up towards the completion point will be enhanced. Policies being implemented are expected to raise real GDP growth to about 5 percent in 2012-13, reduce inflation further by end 2012 and to single digits in 2013. The target for gross official reserves will remain well above the medium-term target floor of 2.5 months of imports. As for the basic balance deficit, the target set in the revised budget is 3.6 percent against 3.8 percent of GDP. The authorities will continue implementing their structural reform agenda to spur strong and sustainable growth in a pro-business environment.

\section{Fiscal policy and reforms}

The authorities will pursue their fiscal efforts to meet the macroeconomic targets under the program. In particular, they will avoid bank financing of the budget deficit, which generated the high levels of inflation experienced in recent years. Due to lower windfall mining revenue and payments that occurred earlier, a revised budget was adopted with additional measures to increase tax revenue and reduce current expenditures. As a result of the measures being implemented in the area of tax and customs reforms, and measures to expand the coverage of VAT and improve the VAT refund system, budget revenue is projected to increase to 20.2 percent in 2013. Expenditures will aim at achieving the target for the basic balance deficit within the envelope of available resources. Domestically-financed investment expenditures are projected to fall to about 5 percent of GDP with the completion of a number of projects. However, allocations for investment mainly in the electricity sector will increase. The authorities will continue to implement the public financial management program with the support of partners including the regulations for the new Organic Budget Law, the recently adopted tax reform plan. 


\section{Public debt management}

The authorities are mindful of the need for further improvements in external debt management. In this regard, they are committed to strengthen the management of the country's external debt to fully observe the program's performance criterion related to arrears. Among other measures in this regard, the minister of economy and finance is the now the sole authority who can authorize contracting external public debt. Only grants and concessional loans will be mobilized to finance projects. Moreover, the laws on the SOEs to establish a clear framework under which they can borrow will be revised.

\section{Monetary and financial issues}

The Central Bank will continue to focus on lowering inflation through an adequate liquidity management including the weekly foreign exchange auctions while taking into account the target for international reserves. Based on progress made with the decline in inflation and the stabilization of the exchange rate, the authorities are committed to further improve the foreign exchange market, strengthen banking supervision and adopt a new banking law by end-2012. In addition, an agreement on the treatment of the outstanding stock of advances to the Treasury will be signed before end of 2012. The authorities are also conducting a study on the financial sector's development with the assistance of development partners. This study will help address the weaknesses of the sector and identify measures to strengthen it so that it can contribute positively to economic growth.

\section{Structural reforms and economic growth}

\section{My Guinean authorities are committed to implementing far-reaching structural reforms} with a view to create a conducive environment for increased investment and economic growth. To this end, their efforts to improve the public financial management, business climate, governance structure for the mining sector and increase investment in electricity and agricultural sector will be intensified, as described in the authorities' letter of intent.

\section{CONCLuSion}

My Guinean authorities' determination to implement sound reforms and prudent policies under the ECF-supported program has helped to restore macroeconomic stability, improve public financial management and make progress in structural reforms. Based on their good performance, I would appreciate Directors' support for my Guinean authorities' requests for the completion of the first review and waiver for non-observance of performance criterion and waiver for modification of performance criteria. I would also appreciate Director's support for the approval of the completion point for Guinea under the Enhanced HIPC Initiative. 